Q2000 International Monetary Fund

March 2000

IMF Staff Country Report No. 00/47

\title{
Nepal: Recent Economic Developments
}

This Recent Economic Development report on Nepal was prepared by a staff team of the International Monetary Fund as background documentation for the periodic consultation with this member country. As such, the views expressed in this document are those of the staff team and do not necessarily reflect the views of the Government of Nepal or the Executive Board of the IMF.

Copies of this report are available to the public from

International Monetary Fund - Publication Services

700 19th Street, N.W. Washington, D.C. 20431

Telephone: (202) 623-7430 - Telefax: (202) 623-7201

Telex (RCA): 248331 IMF UR

E-mail: publications@imf.org

Internet: http:/www.imf.org

Price: $\$ 15.00$ a copy

International Monetary Fund

Washington, D.C. 


\title{
INTERNATIONAL MONETARY FUND
}

\author{
NEPAL \\ Recent Economic Developments
}

Prepared by Wafa Abdelati, Takashi Nagaoka, Eric Sidgwick (all APD), Åke Lönnberg (MAE), and Joseph Zveglich (Asian Development Bank)

Approved by the Asia and Pacific Department

February 4,2000

Contents Page

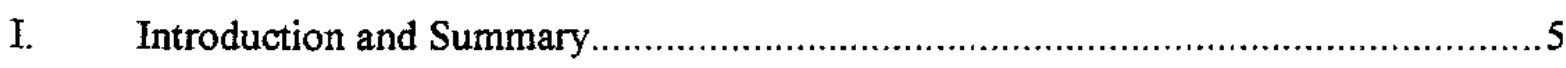

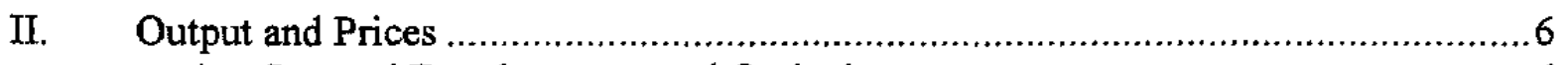

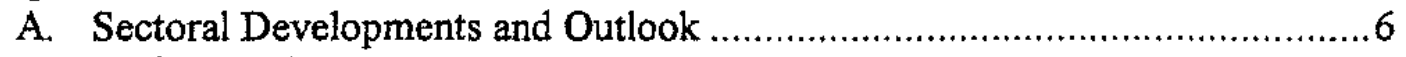

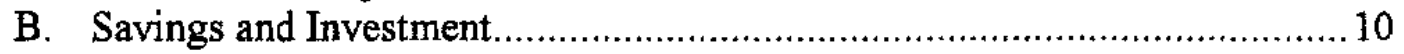

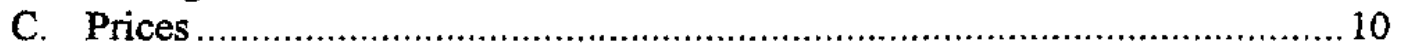

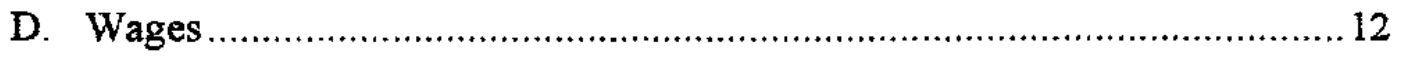

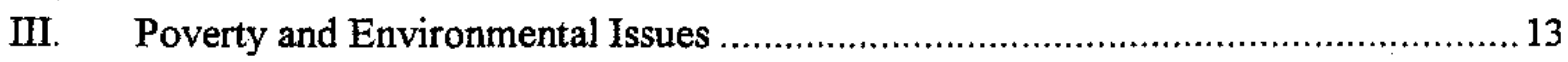

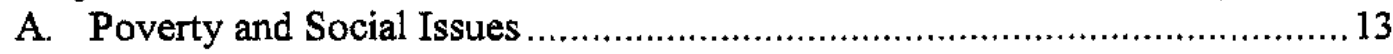

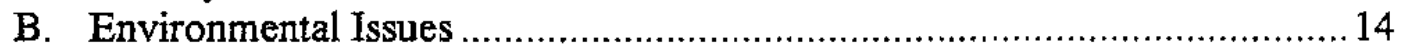

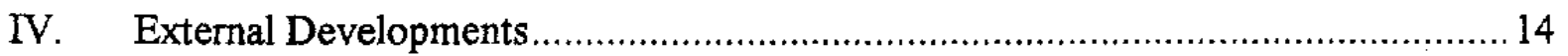

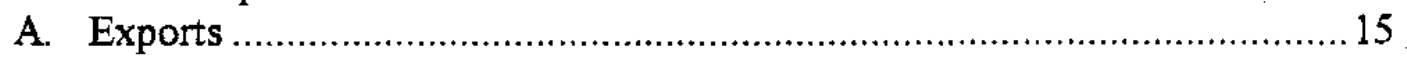

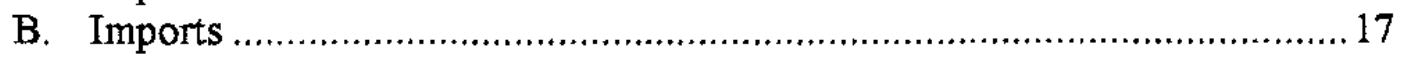

C. Services, Income, and Transfers ......................................................... 17

D. Capital and Financial Account …....................................................18

E. International Reserves and External Debt.............................................18

F. Exchange and Trade System..............................................................20

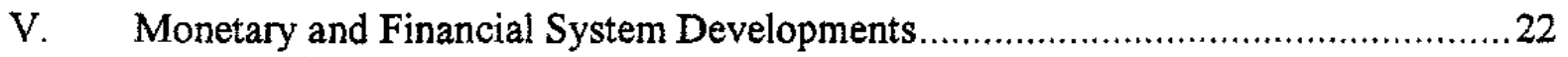

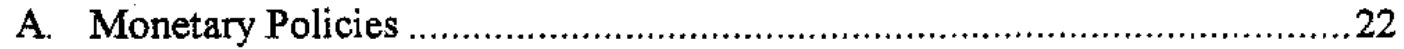

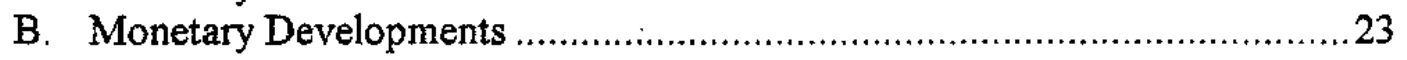

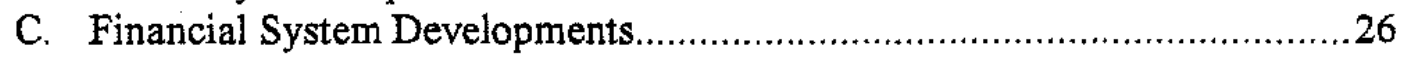

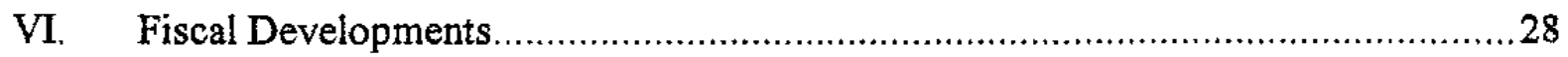

A. Central Government Operations in 1998/99 .........................................30

B. Central Government Budget for 1999/2000 .............................................36 


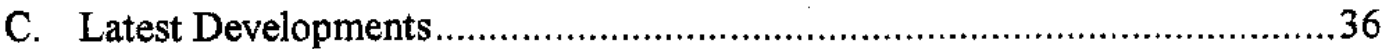

D. Local Government and Off-Budgetary Accounts......................................37

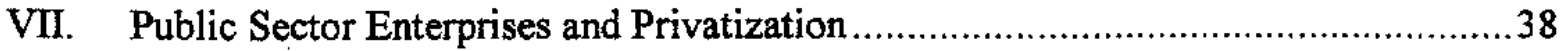

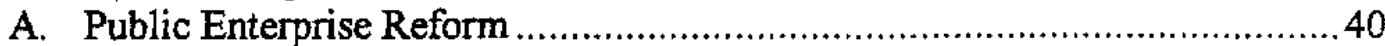

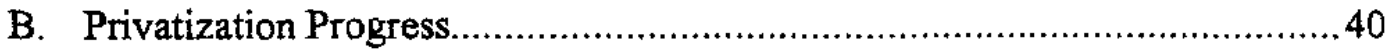

Boxes

1. Liberalization of Fertilizer Trade and its Role in the Agricultural Strategy ...............8

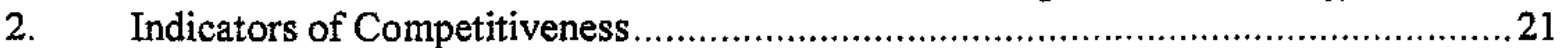

3. Banking Supervision: Areas to Be Strengthened at NRB.....................................29

4. Recent Tax Reform and Key Measures to Strengthen Administration .......................33

5. Constructing Comprehensive Government Accounts ..........................................39

Figures

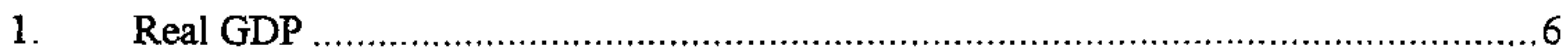

2. Gross Domestic Product by Sector: 1990/91 vs. 1998/99 ..................................... 7

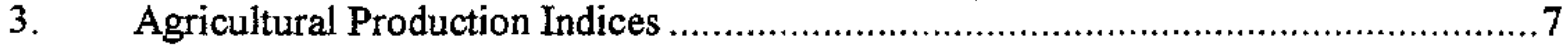

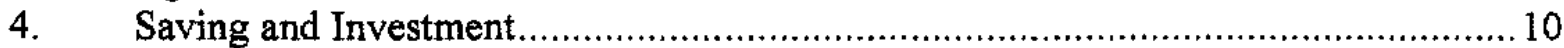

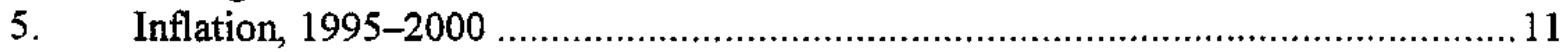

6. External Trade Developments, 1994/95-1998/99 _.............................................16

7. Current Account, Financing, and International Reserves, 1994/95-1998/99 _...........19

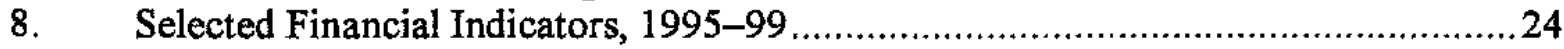

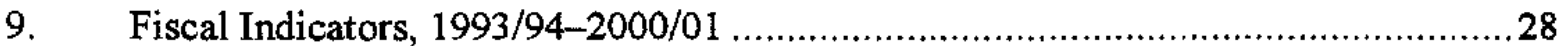

10. Fiscal Developments: Comparison of Budget Outturn 1994/95-1998/99 …............31

11. Composition of Revenue and Expenditure, 1998/99 ............................................34

Tables

1. Selected Economic Indicators, 1994/95-1998/99 _...............................................

2. Comparison of Fertilizer, Electricity and Petroleum Product Prices ......................12

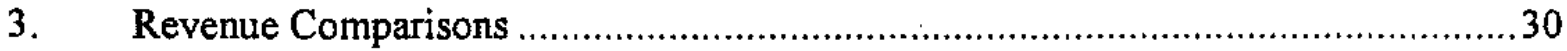

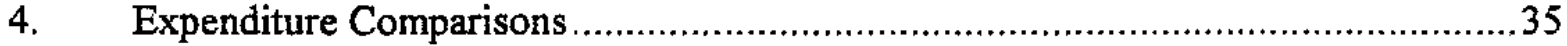

Appendix Tables

1. Nominal Gross Domestic Product by Sector, 1994/95-1998/99 ..........................41

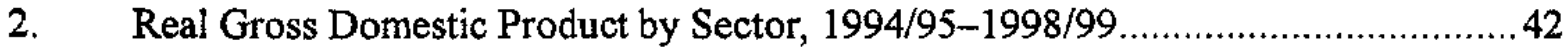

3. Gross Domestic Product by Expenditure Components, 1994/95-1998/99 _..............43

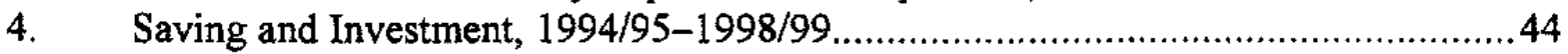

5. Agricultural Production and Yields, 1994/95-1998/99 _....................................45

6. Manufacturing Production Indices, 1995/96-1998/99 ……...............................46

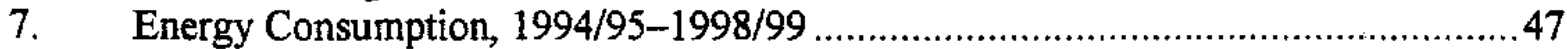

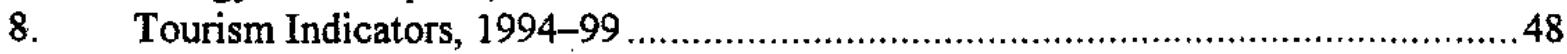


9. Changes in the Consumer Price Index, 1994/95-1998/99 ..................................... 49

10. Monthly Wages in Major Sectors, 1994/95-1998/99 _.......................................... 50

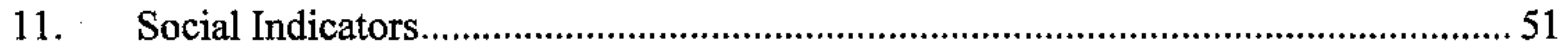

12. Balance of Payments by Area, 1995/96-1998/99 …......................................... 52

13. Composition of Foreign Trade, 1995/96-1998/99 ............................................... 53

14. Exports of Major Commodities, 1994/95-1998/99 .............................................. 54

15. Services and Current Transfers, 1995/96-1998/99,........................................... 55

16. External Debt and Debt Service, 1994/95-1998/99 ............................................. 56

17. Gross International Reserves, 1994/95-1998/99 …......................................... 57

18. Average Customs Duty by Main Category of Goods, $1999 / 2000$.......................... 58

19. Composition of Imports and Import Duties, 1994/95-1998/99 .............................. 59

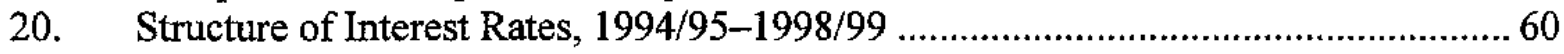

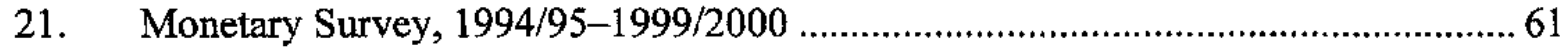

22. Assets and Liabilities of Nepal Rastra Bank, 1994/95-1999/2000 ....................... 62

23. Assets and Liabilities of Commercial Banks, 1994/95-1999/2000 ........................63

24. Assets and Liabilities of Finance Companies, 1996/97-1998/99 ............................. 64

25. Income Statements of Rastriya Banijya Bank and Nepal Bank Limited,

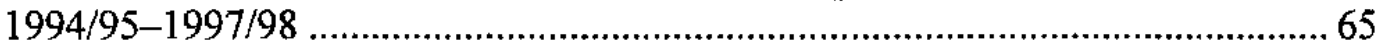

26. Outstanding Bank Credit to Major Public Enterprises, 1994/95-1998/99 .............. 66

27. Nonperforming Bank Loans of Public Enterprises, 1996/97-1998/99 ................... 67

28. Summary of Central Government Operations, 1994/95-1999/2000 ...................... 68

29. Central Government Revenue, 1995/96-1999/2000............................................ 69

30. Central Government Expenditure by Economic Classification,

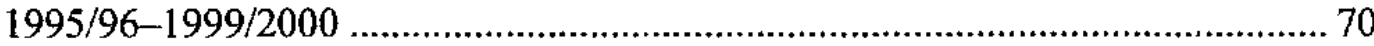

31. Central Government Expenditure by Functional Classification,

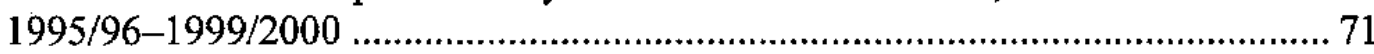

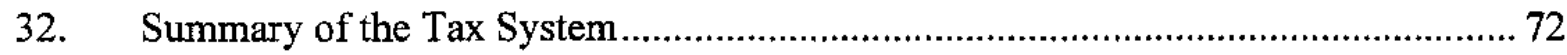

33. Profits and Losses of Selected Nonfinancial Public Enterprises,

34. Interest and Dividend Payments of Public Enterprises to Government

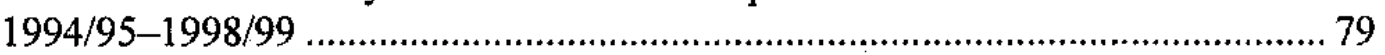

35. Summary of the Privatization Process ............................................................ 80 
Table 1. Nepal: Selected Economic Indicators, 1994/95-1998/99 1/

Nominal GDP (1998/99): US\$4,590 million

Population (1998/99): 22 million
GNP per capita (1998/99): US\$220

Quota: SDR 71.3 million

\begin{tabular}{|c|c|c|c|c|c|}
\hline & $1994 / 95$ & $1995 / 96$ & $1996 / 97$ & $1997 / 98$ & $1998 / 99$ \\
\hline $\begin{array}{l}\text { Growth (percent change) } \\
\text { Real GDP at market prices }\end{array}$ & 3.5 & 5.3 & 5.0 & 2.3 & 3.4 \\
\hline $\begin{array}{l}\text { Savings and investment (percent of GDP) } \\
\text { Gross investment } \\
\text { National savings } \\
\text { Of which: Public savings }\end{array}$ & $\begin{array}{r}25.2 \\
20.5 \\
1.4\end{array}$ & $\begin{array}{r}27.3 \\
18.7 \\
-0.4\end{array}$ & $\begin{array}{r}25.3 \\
22.5 \\
0.8\end{array}$ & $\begin{array}{r}20.7 \\
17.2 \\
0.4\end{array}$ & $\begin{array}{r}16.8 \\
19.4 \\
0.1\end{array}$ \\
\hline $\begin{array}{l}\text { Prices (percent change) } \\
\text { Consumer prices (end of period) } \\
\text { GDP deflator }\end{array}$ & $\begin{array}{l}8.7 \\
6.3\end{array}$ & $\begin{array}{l}9.2 \\
7.8\end{array}$ & $\begin{array}{l}1.7 \\
7.3\end{array}$ & $\begin{array}{r}10.2 \\
3.3\end{array}$ & $\begin{array}{r}9.5 \\
12.5\end{array}$ \\
\hline $\begin{array}{l}\text { Government budget (percent of GDP) } \\
\text { Domestic revenue } \\
\text { Total expenditure } \\
\text { Regular expenditure } \\
\text { Development expenditure } \\
\text { Overall deficit after grants } \\
\text { Overall deficit before grants } \\
\text { Domestic financing (net) }\end{array}$ & $\begin{array}{r}10.4 \\
16.0 \\
6.9 \\
9.0 \\
3.7 \\
5.5 \\
1.3\end{array}$ & $\begin{array}{r}10.8 \\
17.6 \\
7.5 \\
10.0 \\
4.8 \\
6.8 \\
2.0\end{array}$ & $\begin{array}{r}10.5 \\
16.5 \\
7.4 \\
9.2 \\
3.9 \\
6.0 \\
1.4\end{array}$ & $\begin{array}{r}10.7 \\
17.4 \\
7.8 \\
9.6 \\
4.9 \\
6.7 \\
1.9\end{array}$ & $\begin{array}{r}10.1 \\
16.4 \\
7.9 \\
8.6 \\
4.6 \\
6.3 \\
1.3\end{array}$ \\
\hline $\begin{array}{l}\text { Money and credit (percent change; end of period) } \\
\text { Broad money } \\
\text { Domestic credit }\end{array}$ & $\begin{array}{l}16.1 \\
25.1\end{array}$ & $\begin{array}{l}14.4 \\
24.5\end{array}$ & $\begin{array}{l}11.9 \\
13.4\end{array}$ & $\begin{array}{l}21.9 \\
14.8\end{array}$ & $\begin{array}{l}20.9 \\
16.6\end{array}$ \\
\hline $\begin{array}{l}\text { Interest rates } \\
91 \text {-day treasury bill (end of period) } \\
\text { Central bank refinancing } \\
\text { Loans to industry }\end{array}$ & $\begin{array}{r}8.6 \\
11 \\
14-18\end{array}$ & $\begin{array}{r}12.7 \\
11 \\
15-17 \frac{1}{2}\end{array}$ & $\begin{array}{r}5.6 \\
11 \\
15-17 \frac{1}{2}\end{array}$ & $\begin{array}{r}2.4 \\
9 \\
131 / 2-17\end{array}$ & $\begin{array}{r}3.1 \\
9 \\
111 / 2-17\end{array}$ \\
\hline $\begin{array}{l}\text { External trade (percent change) } \\
\text { Export value 2/ } \\
\text { Import value 3/ }\end{array}$ & $\begin{array}{r}-9.9 \\
17.8\end{array}$ & $\begin{array}{r}1.9 \\
12.9\end{array}$ & $\begin{array}{r}10.4 \\
5.3\end{array}$ & $\begin{array}{r}11.9 \\
9.7\end{array}$ & $\begin{array}{r}20.3 \\
-3.1\end{array}$ \\
\hline $\begin{array}{l}\text { Balance of payments (U.S. dollars million) } \\
\text { Current account balance (excluding grants) } \\
\text { (in percent of GDP) } \\
\text { Official grants and loans (net) } \\
\text { Overall balance }\end{array}$ & $\begin{array}{r}-207 \\
-4.7 \\
283 \\
1\end{array}$ & $\begin{array}{r}-390 \\
-8.6 \\
271 \\
-40\end{array}$ & $\begin{array}{r}-142 \\
-2.9 \\
241 \\
59\end{array}$ & $\begin{array}{r}-168 \\
-3.5 \\
294 \\
177\end{array}$ & $\begin{array}{r}131 \\
2.6 \\
247 \\
144\end{array}$ \\
\hline $\begin{array}{l}\text { Other external indicators } \\
\text { Gross official reserves (U.S. dollars million; end of period) } \\
\text { In months of imports of goods and services } 4 / \\
\text { Of which: In convertible currencies } \\
\text { Public and public guaranteed debt/GDP (in percent) } \\
\text { Debt service 5/ } \\
\text { National currency per U.S. dollar (end of period) } \\
\text { Real effective exchange rate (end of period; percent change) 6/ } \\
\text { Nominal effective exchange rate (end of period; percent change) 6/ }\end{array}$ & $\begin{array}{r}702 \\
5.4 \\
4.4 \\
52.1 \\
6.3 \\
50.5 \\
-3.7 \\
-8.2\end{array}$ & $\begin{array}{r}609 \\
4.4 \\
3.6 \\
51.3 \\
6.8 \\
56.3 \\
1.9 \\
1.9 \\
-3.6\end{array}$ & $\begin{array}{r}650 \\
4.3 \\
3.1 \\
48.0 \\
5.0 \\
56.8 \\
5.9 \\
6.8\end{array}$ & $\begin{array}{r}716 \\
5.2 \\
4.3 \\
50.5 \\
5.7 \\
67.6 \\
0.2 \\
-7.8\end{array}$ & $\begin{array}{r}791 \\
4.7 \\
4.3 \\
49.9 \\
5.2 \\
68.5 \\
7.2 \\
-1.5\end{array}$ \\
\hline $\begin{array}{l}\text { Fund operations (outstanding loans at end of period; SDR milion) } \\
\text { SAF/ESAF }\end{array}$ & 35.1 & 29.8 & 24.6 & 19.6 & 14.7 \\
\hline
\end{tabular}

Sources: Data provided by the Nepalese authorities; and staff estimates and projections.

1/ The fiscal year starts on July 16.

2/ Cumulative, excluding re-exports.

3/ Cumulative, excluding gold.

4/ Ratio is in terms of projected imports of goods and services.

5/ In percent of exports of goods, services, and private transfers; including debt service to the Fund.

6/ Minus sign indicates depreciation of the Nepalese rupee. 


\section{INTRODUCTION AND SUMMARY}

1. Since the 1991 transition to democracy, the government in Nepal has pursued policies intended to promote a modern market-oriented economy with the purpose of improving growth performance and prospects. However, Nepal's growth has been insufficient to raise living standards and annual per capita income remains one of the lowest, at US\$220. Almost 90 percent of the population live in rural areas and are dependent on subsistence farming. The absolute number of people living in poverty may have increased in recent years as population has outpaced agricultural growth. Environmental concerns, closely linked to rural development, have increased. Nepal's growth potential remains limited by its underdeveloped infrastructure, unskilled human resources and poor institutional capacity. Growth has averaged $31 / 2$ percent over the past three years, mainly driven by exports of manufactured goods, and growth of transport and communications.

2. Inflation continues to be strongly influenced by supply shocks, and price developments in India as the Nepalese rupee is pegged to the Indian rupee and supply and trade links are very strong. Following a sharp increase in inflation in fiscal year 1998/99 due to food supply shortages, inflation has declined in the first half of 1999/2000 reaching 2 percent (12-month increase) in December 1999, as food prices stabilized. ${ }^{1}$ There were similar price developments in India.

3. During the past three years, there have been improvements in the external position with continued reserve accumulation. Trade with India has expanded markedly following agreements reached on trade and transit. Aided by continued donor financing, gross official reserves, has continued to increase, reaching US\$850 million in mid-January 2000.

4. The Nepalese rupee has steadily depreciated against the dollar since 1990, but the real effective exchange rate has remained stable since the early nineties. Competitiveness appears to be intact as exports, remittances and official reserves have all steadily increased over the period.

5. Monetary policy accommodated an expansion in monetary aggregates in 1999 and higher domestic financing of government operations. Liquidity in the banking system increased, partly reflecting a buildup in net foreign assets. Interest rates generally declined, with both lending and deposit rates falling by $1-2$ percentage points.

6. Although the fiscal deficit remains sustainable, financed primarily by foreign aid, budget performance has reflected the prevailing weaknesses in overall fiscal policy implementation. The budget outtum in 1998/99 continued to reflect low revenue and development spending, resulting in domestic borrowing in excess of budget targets. Problems with the implementation of the VAT continue, including inadequate staffing.

'The fiscal year ends July 15 . 
7. Some progress has been made in the areas of price reform, privatization, and financial sector reform. Petroleum and fertilizer prices were raised in October 1999 and fertilizer subsidies eliminated in December 1999. The government has elaborated a financial sector reform strategy and foreign consultants have begun to evaluate the two large banks. The lending capacity of the two banks remains impaired by a high proportion of nonperforming assets. The three public enterprises that were targeted for sale in 1998/99 are now in the final stages of privatization, several others are preparing privatization programs and some enterprises have initiated restructuring programs. However, weaknesses in the legislative framework, limited skilled labor, and inadequate basic infrastructure, continue to impede private sectoral development.

\section{OUTPUT AND PRICES ${ }^{2}$}

8. Real GDP growth reached $31 / 2$ percent in $1998 / 99$. While this exceeds the population growth rate of $2 \frac{1}{2}$ percent, it is still considerably less than the 6 percent projected under the Ninth Five-Year Plan (1997-2002). As in the previous year, performance was constrained by limited agricultural growth (due to adverse weather and fertilizer supply problems) and by low investment. Domestic savings remained stagnant, limiting resources for investment and requiring continued reliance on foreign aid and remittances from abroad. Fueled by temporary food supply problems, inflation initially accelerated to 19 percent in November 1998 before slowing to 2 percent by December 1999, the lowest rate since 1980 . Limited information suggest that real wages may have declined in most sectors in 1998/99.

\section{A. Sectoral Developments and Outlook}

9. The higher overall growth was led by rising industrial output (manufacturing, electricity and construction), which grew by $4 \frac{1}{2}$ percent compared with the $1 \frac{1}{4}$ percent growth in 1997/98. Adverse weather and an unstable political environment constrained growth, particularly in agriculture, services, and sectors driven by domestic investment and demand considerations. With low productivity growth, agricultural growth has averaged 2 percent in the last decade, while nonagricultural growth averaged 7 percent. Nevertheless, the sectoral shares of manufacturing and services have increased only modestly over the 1990's (Figure 1).The share of manufacturing remains below 10 percent of GDP, and although the share of agriculture declined to 40 percent of GDP, it still accounts for 94 percent of total

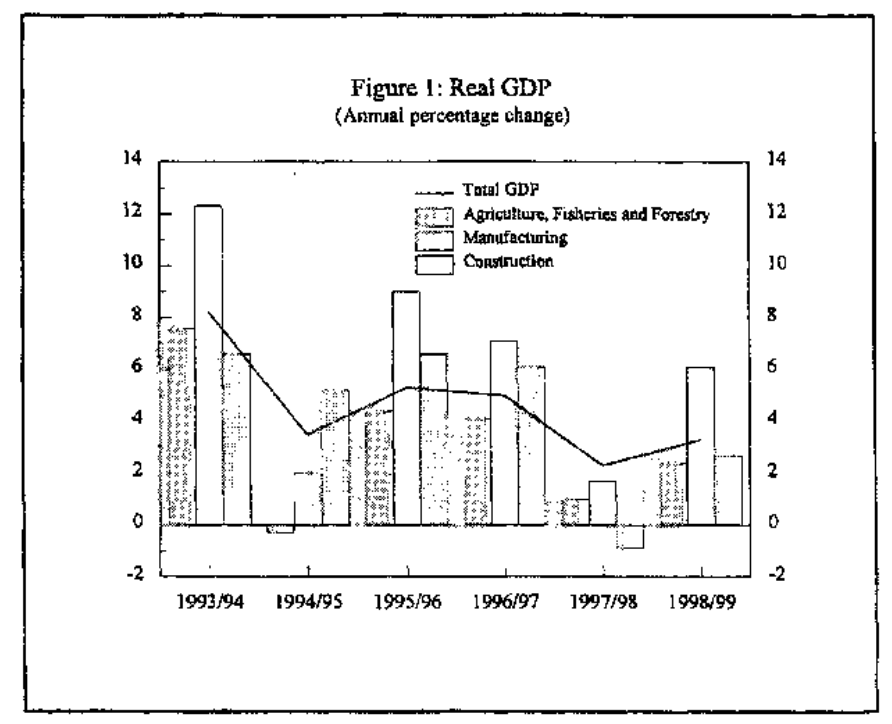

${ }^{2}$ See Appendix Tables 1-10 
employment (Figure 2).

\section{Agriculture}

10. Growth in agriculture was only $2 \frac{1}{2}$ percent in $1998 / 99$, an improvement from the previous year, but barely sufficient to meet the growing rural population and well below potential. Agricultural growth was brought about by a 15 percent expansion in cash crop production (sugarcane, oilseeds and potato) on account of increases in cultivated area and yields (Figure 3). Growth of the principal cereal crops which account for 37 percent of total agricultural GDP remained modest, growing by 2 percent on average. Production of rice, maize and barley was adversely affected by the weather conditions. Livestock production, accounting for one third of agricultural production, grew by $2 \frac{1}{2}$ percent. Vegetable production declined by 11 percent contributing to the sharp price increases.

\section{To promote sustainable rural} growth and reduce poverty, the government initiated the Agricultural Perspective Plan (APP), assisted by the Asian Development Bank (AsDB) under the Second Agricultural Program signed in January 1998. As part of this project, progress has been made to reorganize fertilizer distribution (see Box 1).

\section{Nonagricultural Output}

\section{Manufacturing, and transport and communications, recorded growth rates in} excess of 6 percent. Production of the major exportable items, namely ready-made garments and woolen carpets, picked up markedly in 1998/99. Production of these two items, which account for one third of manufacturing output, increased by 8 and 24 percent respectively, as export markets to Europe expanded (see Section IV below). ${ }^{3}$ Telecommunications services

\footnotetext{
${ }^{3}$ Whereas the value of exports is similar for garments and carpets, the carpet industry's value added is considerably higher, employing over 200,000 (the largest single employer) compared with only 30,000 in the garment sector. Both are eligible for tax benefits and financing facilities as part of the incentives given to priority cottage industries.
} 


\section{Box 1. Liberalization of Fertilizer Trade and its Role in the Agricultural Strategy}

The Government's 20-year Agriculture Perspective Plan (APP) aims to eliminate the structural constraints related to the dominance of state monopolies and to overcome the physical constraints stemming from the rugged infertile terrain, fragmented land ownership, and inadequate road network. The APP focuses on improving the delivery of four inputs: fertilizer, irrigation, road and power, and extension services. Fertilizer use in Nepal (35. kilos per hectare) is considerably lower than in neighbouring countries (88 and 148 kilos per hectare in India and Bangladesh, respectively) and is one of the main reasons for low agricultural productivity.

The strategy pursued to improve fertilizer distribution hinged on removing budgetary subsidies, liberalizing the import of fertilizer trade and leveling the playing field for private sector participation.

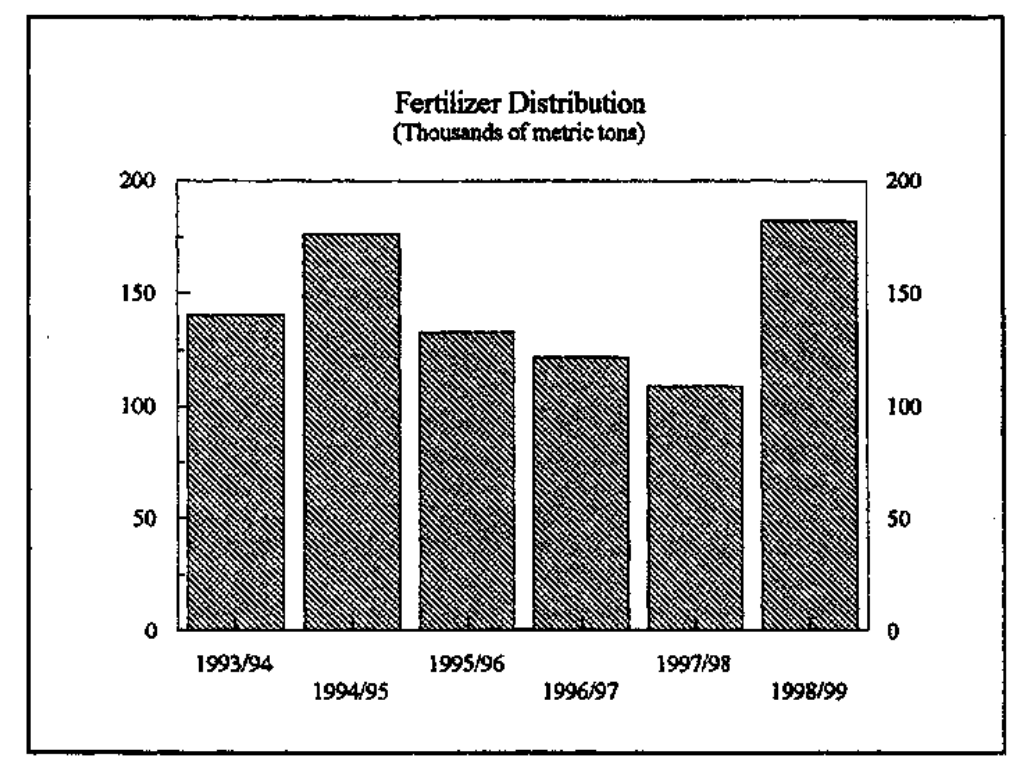

Previously, the state-owned Agricultural Inputs Corporation (AIC) had a monopoly on the import and distribution of chemical fertilizers. Inefficiencies in AIC's operations, however, often led to fertilizer shortages during critical times in the crop cycle. In 1997 , subsidies were removed on all types of fertilizer except urea, importation was liberalized (under an AsDB project), and all traders-both private companies and the AIC-

were allowed to avail themselves of the subsidy on urea. In the last year, significant progress has been made in improving the delivery of fertilizer. However, traders complained that AIC continued to have preferential access to the subsidy due to administrative difficulties. Moreover, AIC's prices failed to cover the cost of procurement and distribution, with the budget covering its losses. In late 1999, the government removed the subsidy on urea. With its monopoly gone, the AIC is undergoing restructuring.

The policy changes have already resulted in increased fertilizer usage, but quality is now a problem. Poor quality and cheaper fertilizer, often adulterated, has been coming in from India where it is heavily subsidized. The Government combated the problem of fraud in the fertilizer trade by adding fertilizer to the Essential Commodities Act, but enforcement continues to be a problem along the open border with India.

Source: Asian Development Bank. 
increased in response to expansion of a program to connect all rural communities to the network and the introduction of cellular services.

13. Construction growth picked up slightly to nearly 3 percent, after negative growth in 1997/98, but this was still less than half the average 6 percent growth over the previous four years. Public investment was low because of delayed development spending. Private sector investment declined in reaction to the overbuilding of hotels and offices in past years and low business confidence.

14. Electricity and water supply - accounting for less than 2 percent of GDP_-picked up from the slump in the previous two years but remains constrained by the availability of financing. In spite of the large hydroelectric potential of Nepal's rivers - estimated at $43,000 \mathrm{MW}$ - the current production capacity is only $300 \mathrm{MW}$ and only 15 percent of the population has access to electricity. The energy supply generated by hydropower has hardly increased since 1995/96. Several projects are being implemented that together would double Nepal's hydropower capacity by $2004 .^{4}$ Nepal's virtually untapped water resources could provide significant irrigation benefits and improve water services. Such services are underdeveloped with only 59 percent of the population having access to safe water, compared with 79 percent in Bangladesh and 81 percent in India.

15. Of the three service sectors, the highest growth rate was recorded in financial and real estate services ( 5 percent), reflecting the expansion of nonbanking institutions. Growth rates in the trade and hotel services and in community and social services slowed considerably relative to the average for the decade. For the latter, this suggests that the 5 percent expansion in civil service employment was partially offset by a contraction in the nongovernment services sector.

16. Tourism arrivals continued to increase but at a slower pace than in previous years, reflecting infrastructure constraints and infrequent air access. Accounting for only 4 percent of GDP, the tourism sector is operating well below its potential though hotel capacity is being increased in Kathmandu. Financial and management problems of Royal Nepal Airlines Corporation (RNAC) have limited the ability to expand major routes and "Visit Nepal 1998" was not as successful as hoped. Recognizing the constraints to tourism expansion, the government dismantled the Department of Tourism and set up the Nepal Tourism Board (NTB), comprising five government and private sector representatives, to

\footnotetext{
${ }^{4}$ Three are public sector projects and four private sector projects. The US $\$ 450$ million Kali Gandaki project, initiated in March 1997, is the largest with a capacity of $150 \mathrm{MW}$ and is less than 50 percent completed due to construction delays. The Mahakali Treaty with India for water-sharing and joint power development in the Mahakali basin was signed in 1996, but the project has been postponed because of initial disagreement on the size of the plant and controversy over rights to use the river. Greater investment in the sector would permit power exports, but India's state electricity boards - the only likely customers-have financial problems and progress has been slow in initiating any major projects.
} 
undertake long-term promotion. Funding is principally provided by earmarking the airport fees charged passengers.

\section{Outlook for $1999 / 2000$}

17. Recent indicators suggest that real GDP growth accelerated in the first half of 1999/2000. The government is projecting 6 percent growth for the year predicated on improved weather conditions and greater political stability. The favorable monsoon, additional irrigation facilities, timely supply of chemical fertilizer, and increased area under paddy cultivation are expected to raise agricultural output by over 4 percent. In the utilities sector, the expected completion of the 14 MW Modhi Khola and 6 MW Puwa Khola hydropower projects, as well as some smaller projects and increased transmission coverage, will raise the output of this sector by 11 percent. Strong growth in the country's major industrial products, driven in part by stable trade relations with India and rising demand for carpets and garments from third countries, is boosting manufacturing output.

\section{B. Savings and Investment}

18. The saving-investment gap halved to under 4 percent of GDP, reflecting a small increase in the savings ratio and a large drop in investment (Figure 4). ${ }^{5}$ The share of gross domestic investment in GDP declined to $163 / 4$ percent of GDP in $1998 / 99$, down from 27 percent in $1995 / 96$ due entirely to a consistent decline in private investment. Gross national savings rebounded somewhat from the sharp decline in $1997 / 98$ as large private transfers offset the declines in public savings (Section VI).

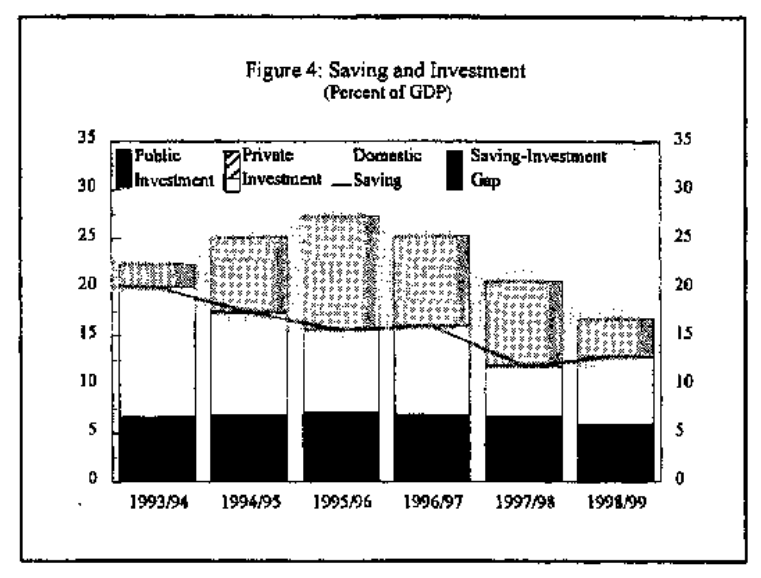

\section{Prices}

19. Inflation, as measured by the consumer price index (CPI), has recently subsided following the earlier acceleration in 1998 brought about by food supply shortages in Nepal and India. Average inflation increased from 4 percent to 12\%/4 percent in 1998/99 driven by higher food prices. End-period inflation peaked at 19 percent in December 1998 as food prices rose due to poor monsoon conditions throughout the region. In India, inflation, as

\footnotetext{
${ }^{5}$ Savings and investment data should be interpreted cautiously as the national accounts data are rudimentary. Private savings are calculated residually and are affected by external account measurement problems (see Section IV). Public sector savings are estimated by adjusting for the recurrent component of development spending, estimated at about 25 percent.
} 
measured by the CPI, followed a similar path. However, from that peak inflation initially declined faster than in Nepal (Figure 5).

20. Prices of food and beverages-with over 60 percent of the total weight in the CPI-were nearly 30 percent higher in December 1998 than one year earlier. While the sharp increase in the prices of vegetables and fruits and subsided in the second half of the year, the price of food grains (especially rice paddy) rose in the summer. Exports of rice also altered the monthly path of prices such that the usual downturn after the main harvest did not materialize. Poor weather condition in the region increased the demand for rice exports to Bangladesh and India in the first quarter, and caused shortages of essential products including edible oils, potatoes, onions and spices,

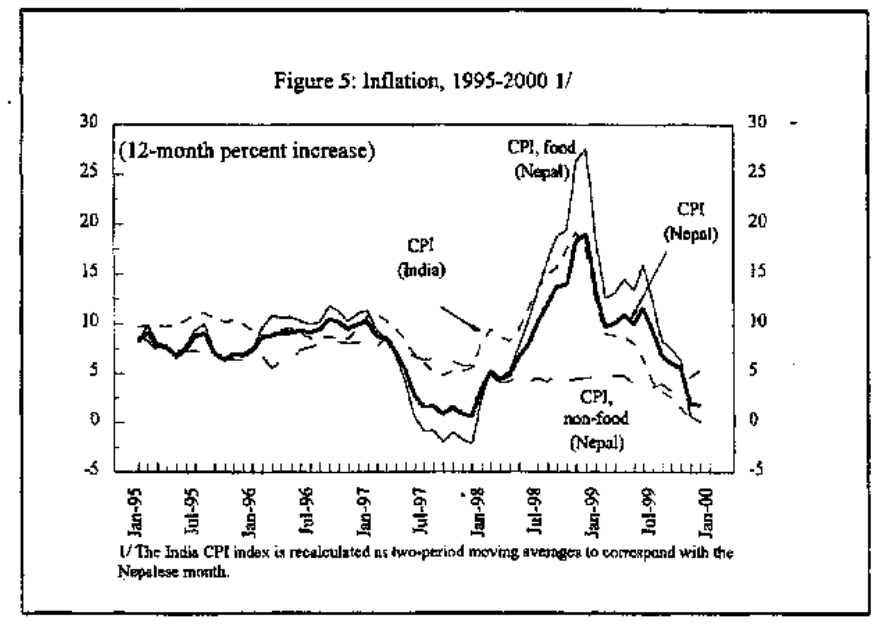
in Nepal and India. Some traders, angered by the newly implemented VAT, used the opportunity to add to the general price hike.

21. In contrast, inflation from nonfood items was moderate. This reflected the fact that key components in the CPI were administratively held constant in the face of increases in the overall price level and international prices. The key administered prices, which were later adjusted, include fertilizer, electricity, kerosene, and diesel.

22. Inflation continued to decelerate in the first half of 1999/2000. In the first five months of the year, inflation fell to 2 percent (12-month period), reflecting a good monsoon which reduced the prices of major crops. Rice prices declined in November/December, and wheat and wheat flour prices are expected to fall in early 2000, reflecting the respective timing of harvest. Meanwhile, the government increased some administered prices to narrow the gap with international prices and help cover costs and losses of the public enterprises. Kerosene and diesel prices were raised by 24 and 48 percent, respectively, in October/November; electricity prices by 30 percent for residential uses in November/December; and fertilizer prices by 10 percent in September. ${ }^{6}$ Fertilizer and kerosene prices are now much higher than in neighboring India where they are heavily subsidized (see Table 2). These price adjustments will feed through to the CPI to counter the expected impact of lower food prices in the early months of 2000 .

${ }^{6}$ The price increases met with substantial resistance and extended parliamentary debate. 
Table 2. Comparison of Fertilizer, Electricity and Petroleum Product Prices

\begin{tabular}{|c|c|c|c|c|}
\hline & \multirow[t]{2}{*}{ International } & \multicolumn{2}{|c|}{ Nepal } & \multirow{2}{*}{$\frac{\text { India }}{\text { As of Oct } / 991 /}$} \\
\hline & & As of July/98 & As of Oct $/ 99$ & \\
\hline \multicolumn{5}{|l|}{ Fertilizers $(\$ / M T)$} \\
\hline Urea & $1492 /$ & 109 & 127 & 98 \\
\hline DAP & 215 & 274 & 308 & 155 \\
\hline \multicolumn{5}{|l|}{ Electricity } \\
\hline Average tariff $(\$ / M w h)$ & $\ldots$ & 73 & $93 \quad 3 /$ & 40 \\
\hline Breakeven price $(\$ / M w h)$ & $\ldots$ & 89 & $\ldots$ & $\ldots$ \\
\hline \multicolumn{5}{|l|}{ Petroleum products ( $\$ /$ liter) } \\
\hline Petrol & $1.40 \mathrm{4} /$ & 0.59 & 0.58 & 0.61 \\
\hline Diesel & $0.85 \quad 4 /$ & 0.24 & 0.34 & 0.34 \\
\hline Kerosene & $0.225 /$ & 0.15 & 0.19 & 0.07 \\
\hline
\end{tabular}

Sources: AIC, NOC, Bloomberg Commodities Service, and Fund staff estimates.

1/ Prices of diesel were increased in October 1999.

2/ Import cost of fertilizer purchased by AIC, November 1999.

3/ As of December 1999.

4/ Estimates of average retail price in European OECD countries.

5/ Wholesale cost of kerosene purchased by the NOC from vessels on the open seas, November 1999.

\section{Wages}

23. Despite the large increase in the CPI in 1998/99, wage developments remained fairly steady overall with some variation across sectors, regions, and skill levels. Wages in agriculture and industry remained unchanged in the last two years, with the exception of a small increase in the Biratnagar region. ${ }^{7}$ Industrial wages may, however, adjust upward next year as inflation is generally reflected in industrial wage increases with a 1-2 year lag. Construction wages increased in the southern regions (in the range of 16-23 percent) but remained stable in the Kathmandu valley. To reduce the decline in real wages in the public sector, the government increased allowances to all civil servants by Nrs 300 per month in August 1999. After the increase, the average take home pay (including allowances) of a public sector employee is about US\$47 per month. The public sector pay scale is very compressed. ${ }^{8}$

24. Accordingly, real wages and wages expressed in U.S. dollar terms have been on the decline since 1995/96. In the Kathmandu region, agriculture and construction wages are about 15 percent lower in real terms than three years earlier. Real wages in the industrial

${ }^{7}$ Industry wage data are based on information provided on minimum wage developments as actual average wage data are not available.

${ }^{8}$ Senior officials reportedly receive a lower salary than junior associates in private commercial banks. 
sector declined in 1998/99, reversing the increases of the previous year, and are now slightly below their level of three years earlier.

25. The government recently approved a minimum wage of Nrs 70 (US\$1) per day for the agricultural sector in Kathmandu. It is expected that this will become a benchmark for minimum wages in other sectors and regions. Actual wages in the private sector would be negotiated based on such minimum wages. However, the lack of strong enforcement of minimum wages, even in the public sector, casts doubts on the implementation of such requirements in the private sector, especially in small enterprises and among unorganized workers.

\section{POVERTY AND ENVIRONMENTAL IsSUES}

\section{A. Poverty and Social Issues}

26. Overcoming widespread and deep-rooted poverty is Nepal's greatest challenge. Growth has averaged less than 4 percent while population growth has exceeded 2 percent over the past 25 years and employment has grown at a slower pace than the labor force. Recent estimates suggest that the proportion of the population living below the nutritionbased poverty line (defined at somewhat less than US\$1 per day in purchasing power parity terms) is 42 percent, and that 70 percent have incomes less than US\$1 $1 / 2$ per day. Although there have been significant improvements, virtually all of Nepal's social indicators are lower than other low-income countries (see Appendix Table 11). For example, the adult literacy rate is half that of India, and access to safe water and to electricity are three quarters and one quarter the level in India, respectively.

27. Poverty is more acute and pervasive in rural areas. Around 80 percent of the poor farm small and dispersed plots of low-quality land. Many must seek scarce low-wage agricultural employment to supplement their income. Limited work opportunities have maintained underemployment at around 50 percent. Many poor work as bonded laborers to pay off debts and the caste system constrains prospects for labor mobility. Health services are less accessible and more costly in rural areas.

28. Public spending on social and poverty alleviation programs is constrained by the low level of public revenues and its composition is determined by donor assistance programs. Nepal cannot afford to significantly expand the social safety net through domestic resources. Although social expenditure has increased from $3 \frac{1}{2}$ percent of GDP in the mid1980 s to nearly 6 percent of GDP, the allocation remains inadequate, particularly with respect to funding of priority areas.

\section{The Ninth Plan focussed on promoting rural working opportunities and}

improved services. The Plan targeted reducing the number living in poverty to 32 percent by 2002. A number of programs have been initiated, and a Poverty Alleviation Fund has been established to direct and coordinate donor efforts. However, the poverty target will probably not be achieved due to the slow rate of economic growth relative to the growth of the population. To improve the effectiveness of poverty related policies, a new strategy is being developed. Several poverty assessments were recently carried out by local and international 
NGOs (e.g., Action Aid Nepal, Plan International Nepal, and New Era), based on the 1995/96 Nepal Living Standard Survey (NLSS). A National Workshop on Poverty was hosted by the National Planning Commission (NPC) in January 1998. Government initiatives on poverty reduction are widely discussed in committees and public debate.

\section{Efforts to improve project effectiveness include initiatives to promote} decentralization and increased community participation. Projects with successful community participation include community forestry, farmer managed irrigation and the Food for Work program in the Churia region, as well as a number of UNDP and GTZ sponsored projects. However, it is doubtful that community mobilization efforts can be effectively replicated in more remote areas. Also decentralization and revenue sharing arrangements could weaken overall resource mobilization and budgetary control.

31. The International Labour Organization estimates child labor at 10 percent of the total labor force of 12 million, or 42 percent of all 5-14 year old children. Children work mainly in the agricultural sector, and in the carpet and garment factories. The carpet and garment manufacturers have been cooperating with international organizations to eliminate this practice and the incidence of child labor appears to be on the decline.

\section{B. Environmental Issues}

\section{There is a close link between poverty and environmental degradation.}

Environmental degradation in the form of soil erosion and landslides stems from the encroachment onto ever-steeper slopes and into forests in search of firewood and fodder. This in turn has left the poor more vulnerable to recurring natural disasters such as floods and droughts. Air and water pollution are on the rise. In urban areas, sewage and garbage disposal are immediate concerns, with particularly severe implications for the poor in the Kathmandu Valley. To address rising air pollution in Kathmandu, the government recently abolished the use of diesel operated three-wheelers and provided tax incentives to encourage the use of electric-operated microbuses.

\section{EXTERNAL DEVELopments ${ }^{9}$}

\section{Based on available data, the external position remained strong in 1998/99 and} early 1999/2000. However, despite some improvements in coverage made during the last year, the analysis of external sector developments remains hampered by weak data. In particular, the capital account includes large unrecorded capital outflows (captured in large negative errors and omissions), suggesting that imports are under-recorded, perhaps by a significant amount. Bearing these caveats in mind, buoyed by robust growth in exports of goods, services and private transfers, and a decline in imports, the current account (excluding grants) recorded a surplus in $1998 / 99$ of US $\$ 130$ million (about $2 \frac{1}{2}$ percent of GDP). However, contrary to the previous two years, the current account balance with India reverted

\footnotetext{
${ }^{9}$ See Appendix Tables 12-19.
} 
back to a (small) deficit, following a sharp decline in the gold trade. The overall balance remained strong, with both India and third countries, and gross official international reserves were stable at just under $4 \frac{3}{4}$ months of import coverage. Total external debt declined slightly, and the debt service burden remained manageable.

\section{A. Exports}

\section{Merchandise exports continued to perform well in $1998 / 99$, buoyed by greater} diversification and continued growth in exports of ready-made garments and carpets. Exports, f.o.b., including re-exports of oil but excluding re-exports of gold, were up 13 percent in U.S. dollar terms in $1998 / 99 .^{10}$ Exports of carpets and ready-made garments continued to account for the largest share, comprising just under 55 percent of total merchandise exports (Figure 6). Exports of carpets (mostly to Germany and increasingly to the USA) rose by over 5 percent, despite declining U.S. dollar prices, reflecting a rise in export volume to $2 \frac{1}{2}$ million square meters. Exports of ready-made garments jumped by 26 percent, filling the available quotas on exports of men's shirts, shorts and trousers, and women's blouses. Exporters of ready-made garments were the beneficiaries of restrictions placed on Indian exports of garments following the Indian nuclear tests, as many of the Indian exporters were able to quickly switch production to Nepal, and the addition of big buyers from the U.S. ${ }^{11}$ Other exports which performed well in 1998/99 included handicrafts, tea, silverware and jewelry, leather goods, and paper products. With regard to the direction of trade, merchandise exports to India, excluding oil, rose by 36 percent, with strong growth in exports of vegetable ghee, jute goods, pulses, thread, and other products included in the Trade and Transit Agreements with India (see below).

\section{In the first quarter of 1999/2000, total merchandise exports surged by over} 40 percent, spurred by strong growth of exports of ready-made garments and carpets. In contrast, exports of vegetable ghee to India dropped off sharply as the Indian authorities tightened hygiene standards in response to pressure from local producers.

\footnotetext{
${ }^{10}$ In response to STA technical assistance, the authorities have revised their compilation of the balance of payments, from 1996/97 onward (see IMF Staff Country Report No. 99/18; March 1999; p. 14-20). However, the re-exports of gold (to India) are not explicitly included, although a counter-entry to the imported value of gold imports is included in the financial account under "other assets." Some of the counter-entry to the importation of gold also appears in workers' remittances under private current transfers. In the staff's presentation of the balance of payments, re-exports of gold are included in total exports.

${ }^{11}$ Carpet exporters already benefit from the Generalized System of Preferences (GSP) of the European Union, and are not subject to any local value-added requirements. Exporters of ready-made garments are to enjoy similar benefits effective January 1, 2000.
} 
Figure 6: External Trade Developments, 1994/95-1998/99

(In millions of U.S. dollars; unless otherwise noted)
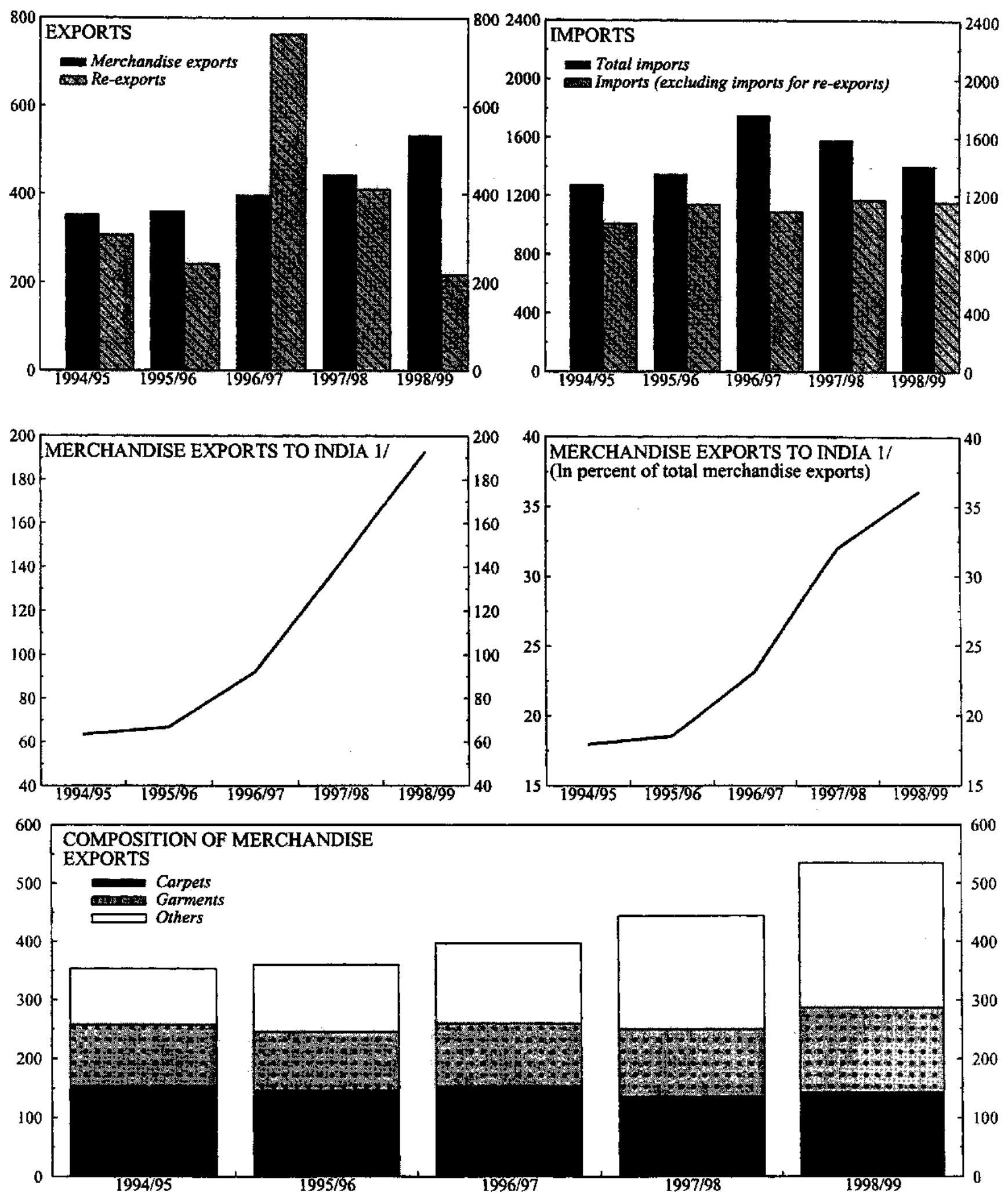

Source: Data provided by the Nepalese authorities.

1/ Excluding re-exports. 


\section{B. Imports}

36. Import growth was negative in 1998/99. Imports, including oil, declined 11 percent in U.S. dollar terms to US\$1,405 million. ${ }^{12}$ The composition of imports remained unchanged from previous years, with the bulk of imports consisting of manufactured goods and capital equipment. Imports of food and medical supplies originate mostly from India, while minerals and raw materials come predominantly from third countries. An increase in imports from India (to US\$600 million), mostly on account of higher imports of food (especially rice) and live animals, cotton fabrics, medicines, and some capital equipment, was more than offset by lower imports from third countries, which fell by 19 percent to US $\$ 800$ million. The largest decline was in imports of gold (around 50 percent), following the reduction in the tariff on gold in India and the related decline in transit gold trade through Nepal to India. In addition, consistent with lower development expenditures, declines were also recorded in imports of crude materials (raw wool from New Zealand and Tibet), petroleum products, and capital equipment (transport goods).

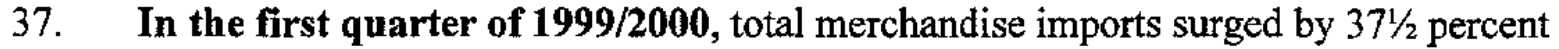
on an annual basis resulting from a significant increase in imports of gold. Imports of thread and cotton, for the garment industry, and fertilizer and cement, also rose sharply.

\section{Services, Income, and Transfers}

\section{Total gross service and income receipts increased by 26 percent to}

US\$546 million in 1998/99. Receipts from tourism, which represents the largest share of service receipts, rose by 12 percent to US\$179 million due to an increase in average expenditure-per-tourist (to over US\$470); the total number of tourists visiting Nepal increased only marginally, to just under 465,000 . Service receipts from India increased by 30 percent following the first time inclusion of expenditures by the Indian embassy (about US $\$ 45$ million), and higher expenditures by resident diplomatic missions and aid agencies. Total service payments remained constant at US\$232 million.

\footnotetext{
${ }^{12}$ Oil products are bought by the Nepal Oil Corporation (NOC) in U.S. dollars from oil exporting countries and shipped to India for storage at various ports. Since there is a change in ownership (from oil exporters to the NOC), the transaction is recorded as an import in the balance of payments, although the oil does not physically cross the border into Nepal. Nepal "re-exports" oil to India (to the Indian Oil Corporation (IOC)) for storage purposes and the IOC pays for the oil in Indian rupees. Reflecting the further change of ownership of the oil, the transaction is recorded as a "re-export" in the balance of payments. Finally, oil products (petrol, diesel, kerosene, and aviation fuel) are imported back into Nepal as and when required. This final change in ownership is again recorded as an import in the balance of payments. Because payments by NOC to IOC for the oil (in Indian rupees) include all associated transport and storage fees, and duties, the import bill is higher by a margin of between 20-25 percent than the receipt from the "re-export."
} 
39. Recorded private current transfers rose $241 \% 2$ percent to US\$172 million.

Remittances of pension payments, from retired Nepalese soldiers in the Indian and Ghurka armies, increased by 44 percent to US $\$ 80$ million, following increases in pensions for retired army personnel from both armies. ${ }^{13}$ Non-recorded private remittances from Nepalese workers working abroad (mostly in the Middle and Far East, and India) are estimated to have risen by 29 percent to US $\$ 315$ million. ${ }^{14}$ Official grants declined by 10 percent to US\$107 million. Official cash grants from bilateral donors, other than India, rose 16 percent to US $\$ 43$ million, while grants from India fell to US $\$ 19$ million and grants-in-kind declined by more than half to only US $\$ 7 \frac{1}{2}$ million. Other grants declined by US $\$ 6$ million to US $\$ 381 / 2$ million.

\section{Capital and Financial Account}

\section{Though it remained strong, the overall balance surplus declined by} US\$33 million to US\$144 million. Private and official capital transfers declined significantly to under US\$30 million, and US\$110 million, respectively, in line with the decline in capital expenditures. Direct investment, which remains very limited consisting of only equity investment, fell marginally to US\$9 million. Disbursements declined by US\$35 million to US\$195 million, about half the rate of decline in development expenditures, while amortization payments remained constant. Trade credits (net) declined to close to zero in $1998 / 99$, from a level of about US\$70 million, in line with the decline in the prepayments of outstanding letters of credit and export bill purchases.

\section{E. International Reserves and External Debt}

41. Reflecting the strong balance of payments, gross foreign assets of the banking system continued to increase in 1998/99, to US\$1.1 billion. Gross foreign assets of the Nepal Rastra Bank (NRB) rose to US\$800 million, including US\$780 million in foreign exchange reserves, equivalent to $4 \frac{1}{2}$ months of import coverage. During the year, the share of Indian rupees in total foreign exchange reserves of the NRB declined sharply from 24 percent to 9 percent, reflecting the combination of lower re-exports of gold to India and the NRB's policy of gradually reducing its holdings of Indian currency (Figure 7). Reserve accumulation by the NRB continued in 1999/2000, reaching US $\$ 857$ million by mid-January 2000.

\section{Total external debt rose slightly to US\$2.7 billion by the end of $1998 / 99$ but} declined in terms of GDP, to just under 54 percent. The share of multilateral debt remained stable at 80 percent, while that of short-term non-concessional debt, consisting

\footnotetext{
${ }^{13}$ As reported in the exchange record of commercial banks.

${ }^{14} \mathrm{~A}$ recent in-depth study, sponsored by the U.K. Department for International Development (DFID) suggested that unrecorded workers' remittances were significantly larger than currently estimated. If true, this would indicate some under-recording of outflows elsewhere in the balance of payments.
} 
Figure 7: Current Account, Financing, and International Reserves, 1994/95-1998/99 (In millions of U.S. dollars)
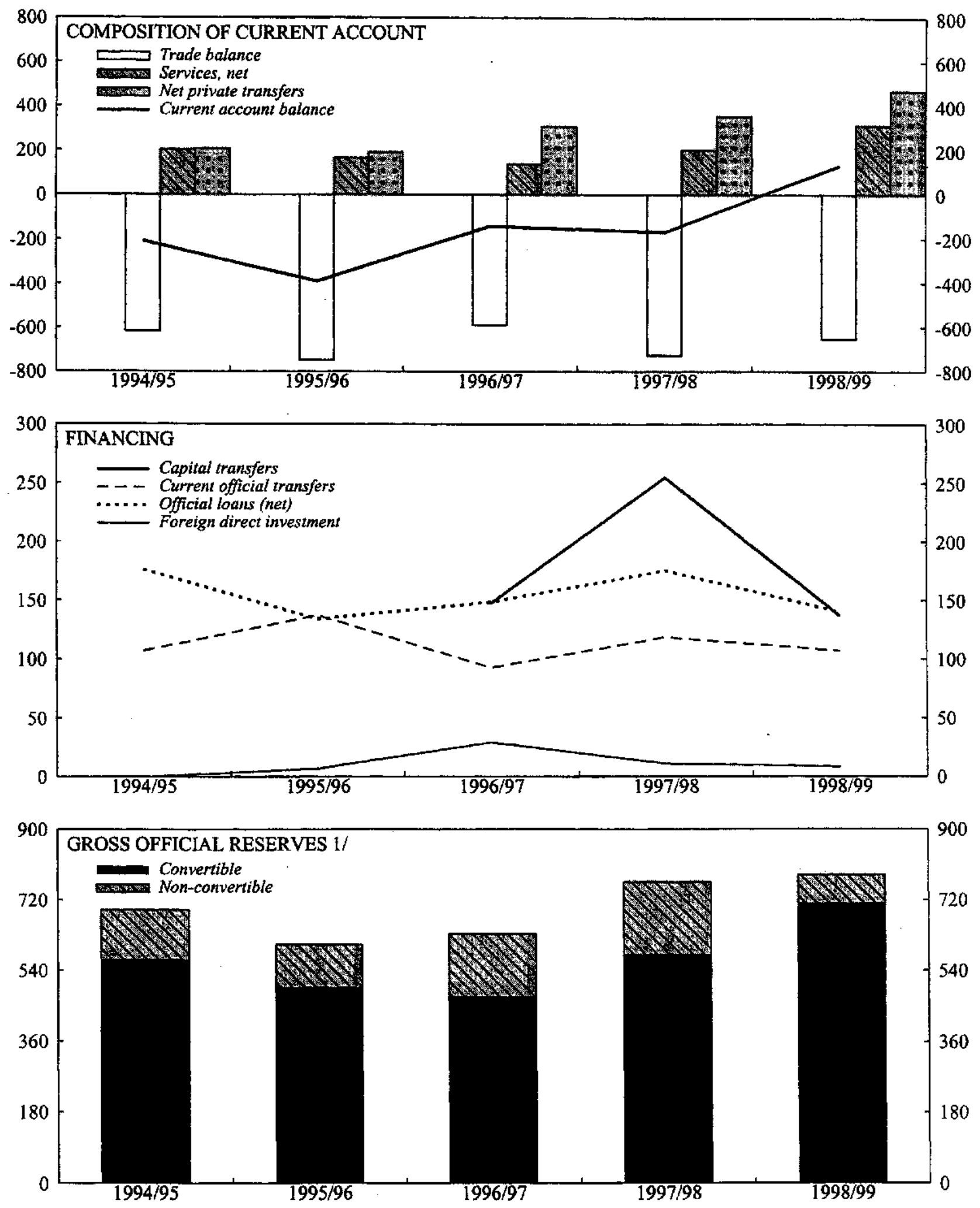

Source: Data provided by the Nepalese authorities.

1/ Including gold, SDR holdings; and the reserve tranche position. 
mostly of trade credits, remained small (under 8 percent). The debt service ratio declined to just over 5 percent.

\section{F. Exchange and Trade System}

43. The exchange rate of the Nepalese rupee remains pegged to the Indian currency at the rate of Nrs 1.6 per Indian rupee. The Nepalese rupee broadly maintained its nominal exchange rate against the U.S. dollar, appreciating in real effective terms by about 7 percent in the year to mid-July 1999. This appreciation reflected the increase in CPI inflation and the widening inflation differential with India. However, this appreciation was reversed in the first half of 1999/2000, in line with the improvement in inflation performance, and there is no evidence to suggest that this resulted in any loss in competitiveness (see Box 2).

44. Though Nepal maintains an exchange system that is free of restrictions, some minor controls were imposed in $1998 / 99$ and $1999 / 2000 .{ }^{15}$ In late 1998 , temporary quantitative restrictions were imposed on the import of poppy seed and the export of rice (for the latter, in response to a shortage in domestic production). In early 1999 , cotton yarn, raw materials used for manufacturing toothpaste, and detergent were added to the list of items imported from India which have to be paid in foreign exchange, to discourage exporters from hoarding foreign exchange. In addition, to protect local producers, the import duty on sugar imports was raised to 40 percent in January 2000. Concomitant with the adoption of a transaction-based customs valuation system (see Section VI), the tariff rates of 20 and 30 percent were eliminated, and the tariff structure now includes five standard rates $(5,10,15,25$, and 40 percent), plus two special rates of 80 and 130 percent, applicable to arms and ammunitions, and certain motor vehicles, respectively. Notwithstanding the changes, the average effective tariff rate remains at around 8 percent. ${ }^{16}$

\footnotetext{
${ }^{15}$ See Annual Report on Exchange Arrangement and Exchange Restrictions, 1999.

${ }^{16}$ Average customs duty rates by main categories of goods and the overall simple average custom duty rate are shown in Appendix Table 18.
} 


\section{Box 2. Nepal: Indicators of Competitiveness}

In Nepal, it is not possible to derive a unique yet comprehensive measure of competitiveness. In theory, assessment of a country's international competitiveness is based on measuring the costs of domestically producing tradable goods and services, or equivalently, relative prices or the real exchange rate (RER). The higher the domestic cost of producing tradable goods and services (i.e., the more appreciated the RER), the lower the country's degree of competitiveness. One common method of assessing competitiveness is to evaluate how far the current RER is from its equilibrium value,

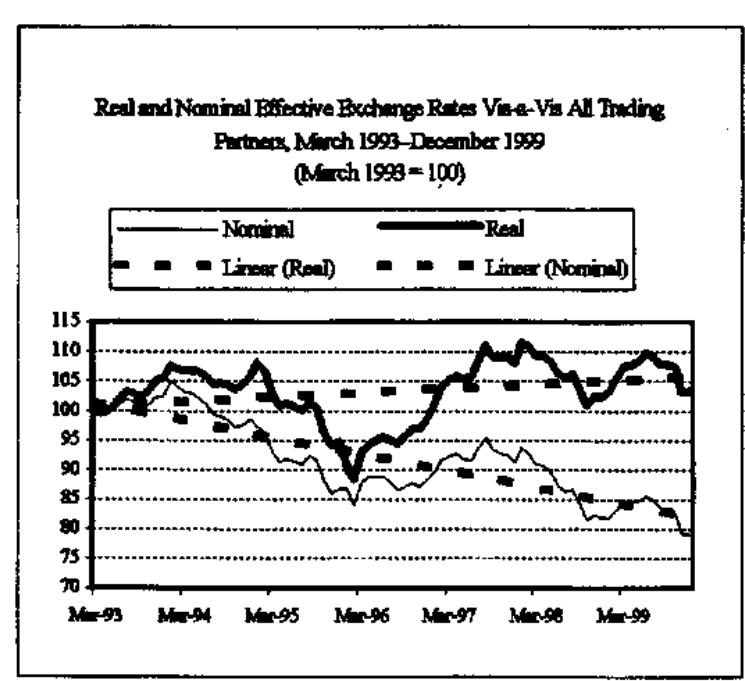
defined as the relative price of tradables to nontradables at which income and expenditure, and the supply and demand of tradables and nontradables, respectively, are equal. In Nepal, as in many developing countries, the application of such an analytical framework is difficult, partly because of the lack of necessary data, but more importantly, because the equilibrium exchange rate is constantly changing in response to the structural shifts in the economy.

Therefore, as an alternative, the staff looked at three available indicators to assess competitiveness. First, Nepal's real effective exchange rate (REER), defined as trade-weighted nominal exchange rates deflated by relative CPIs, has remained broadly stable since being pegged to the Indian rupee in early 1993, except for a brief period centered around 1996. This indicates that domestic casts do not appear to have eroded competitiveness. Second, in support of this assessment, since the beginning of 1998/99, average wages have not increased in either of the main export sectors (carpets and readymade garments). In fact, though reliable data on wages are not readily available for all export sectors, real average wages in the export sector may have fallen over the period. Finally, total merchandise exports, including to India, and gross official international reserves have all increased over the period. Thus, persistent increases in foreign exchange inflows do not indicate a widespread loss of competitiveness.

Available indicators do not suggest that

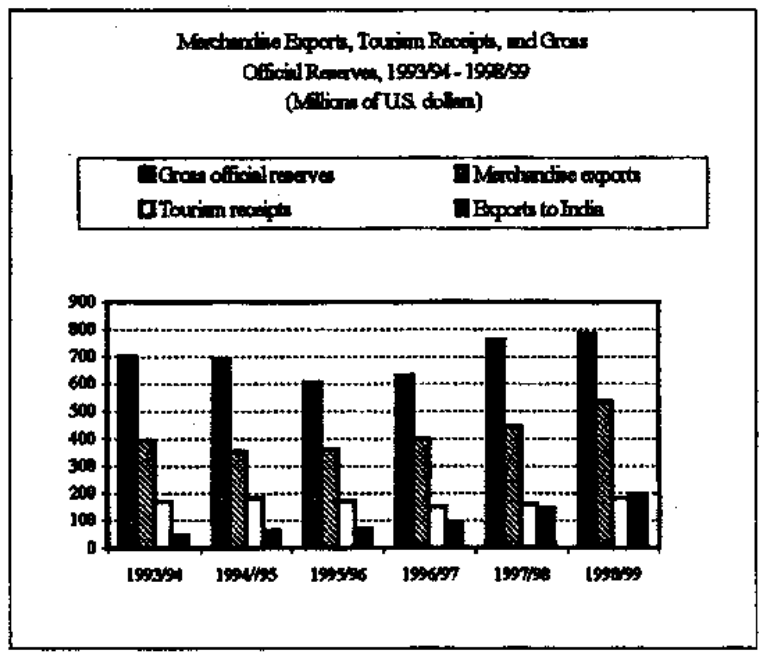
Nepal's competitiveness has been eroded in recent years. However, there is a clear need to develop better indicators to enable not only a more accurate assessment of competitiveness, but also closer monitoring. In particular, the recent increase in energy costs and the prospect of higher water rates (an important input for producing carpets) could lead to a decline in competitiveness, especially in the non-garment export sectors where the absence of quotas renders competition more intense. In addition, some readily available indicators, such as advanced export orders and hotel reservations, should be monitored as these can serve as early-warning signals of potential problems. 
45. Nepal had submitted its application to the World Trade Organization (WTO) along with the initiating memorandum on its foreign trade regime. With the assistance of the UNDP, work has begun on drafting the "initial offers" document, and assessing the revenue impact of potential tariff reductions. The "initial offers" will include proposals to open up the service sector, including banking, insurance, and telecommunications. The First Working Party meeting is to be held in the first quarter of 2000 .

46. The Nepal-India Trade Agreement signed in December 1996, is anticipated to be automatically renewed in December 2001, as the agreement has proved beneficial to both sides. Under the trade agreement, Nepal can export all manufacturing goods to India duty free on the basis of a certificate of origin. The only exceptions are alcoholic beverages, tobacco and cigarettes, and perfume and cosmetics, which are subject to Indian customs duties. As explained above, since the signing of the agreement, trade has shown an increasing trend. The Nepal-India Transit Agreement, which has simplified procedures to expedite the transportation of cargo to Nepal from Indian ports, was renewed in January 1999 for seven years, and now includes an automatic renewal provision.

47. The authorities are currently reviewing a draft of the South Asia Free Trade Agreement (SAFTA) which is scheduled to take effect in 2001, although the SAFTA is not expected to have a significant effect on Nepalese trade or revenue if the preferential trade agreement with India is maintained. However, SAFTA could have large revenue implications in the event the trade agreement with India is not renewed as trade would be diverted to the free trade area.

\section{Monetary and FinanCial, System Developments ${ }^{17}$}

\section{A. Monetary Policies}

48. Since mid-1998, the NRB has aimed to simultaneously allow credit expansion to support output growth at the same time as reducing the potential for monetary expansion to fuel inflation. The NRB conducts its policy via cash reserve ratio (CRR), the refinancing rate, and open market operations using treasury bills and repurchase agreements. The NRB currently does not have a discount window system. With such instruments, the NRB's leverage is still limited in practice, due to the lack of a developed market for government securities and a limited range of debt instruments. ${ }^{18}$ To address such constraints, longer-term government securities were introduced in 1997 and efforts made to reduce the NRB's finance to the public sector. Interest rate policy has been conducted primarily through moral suasion to bring lending rates down while discouraging significant upward movement in yields on treasury bills.

\footnotetext{
${ }^{17}$ See Appendix Tables 20-27.
}

${ }^{18}$ Longer-term NRB bonds have not been issued since September 1996 and the last redemptions were made in April 1997. 
49. For 1998/99, the NRB projected annual broad money growth of 15 percent, consistent with average inflation of 7 percent and a modest decline in velocity, while accommodating private sector activities. ${ }^{19}$ To encourage the desired reduction in lending rates, the NRB issued a requirement that all commercial banks keep their spread between deposit and lending rates to 5 percentage points. ${ }^{20}$ To help meet this objective, the bank refinancing rate and CRR were kept unchanged. ${ }^{21}$ Though the NRB's conduct of monetary policy was hampered by legal and operational restrictions, it made no attempt to sterilize the increase in net foreign assets (NFA) and accommodated the higher credit to government. ${ }_{-}^{22}$

\section{B. Monetary Developments}

50. In the context of the NRB's passive monetary stance, broad money grew by 21 percent in 1998/99, similar to the growth in 1997/98. This expansion was higher than in India (14 percent during the corresponding period), reflecting the general trend difference in velocity (Figure 8). Narrow money growth slowed to 13 percent from more than 17 percent in the previous year, including a substantial deceleration in the growth of domestic demand deposits. However, there was a significant increase in time deposits, reflecting the lack of other attractive investment avenues and investors' relative confidence in commercial banks. NFA grew significantly, though at a decelerated pace, due to compression of imports, higher exports, and increased foreign capital inflows from donors.

51. In the first months of 1999/2000, annual broad money growth has remained at about 20 percent. ${ }^{23}$ Growth of net domestic assets exceeded that of NFA growth (both after adjustments for valuation changes), spurred by acceleration in credit to the government.

\footnotetext{
${ }^{19}$ Percentage changes are on 12-month basis unless indicated otherwise.

${ }^{20}$ Lack of a clearly defined method for calculating interest rate spreads made it difficult to evaluate individual banks' interest rate settings and thus added to doubts on the effectiveness and appropriateness of the directive.
}

${ }^{21}$ The bank refinance rate was reduced from 11 to 9 percent in December 1997 and further lowered to 7 percent in July 1998 against loans provided for exports. The CRR was slashed from 12 percent to 10 percent on average (discriminatory by type of deposits) in April 1998.

${ }^{22}$ There are restrictions on selling the bills acquired from converting the overdraft in the primary market and limits on the level of gross sales of treasury bills. These, together with the regulation linking the rate in the secondary market to the average of the preceding three months' primary market rates, limited the NRB's capacity to conduct its open market operations.

${ }^{23}$ As the most recent figures in the monetary survey are based on estimates from a sample of operating branches, they are subject to revisions after 4 months, which usually push up M2 growth figures by 1-2 percentage points. The figures referred to here are adjusted for this bias. 
Figure 8: Selected Financial Indicators, 1995-99 1/
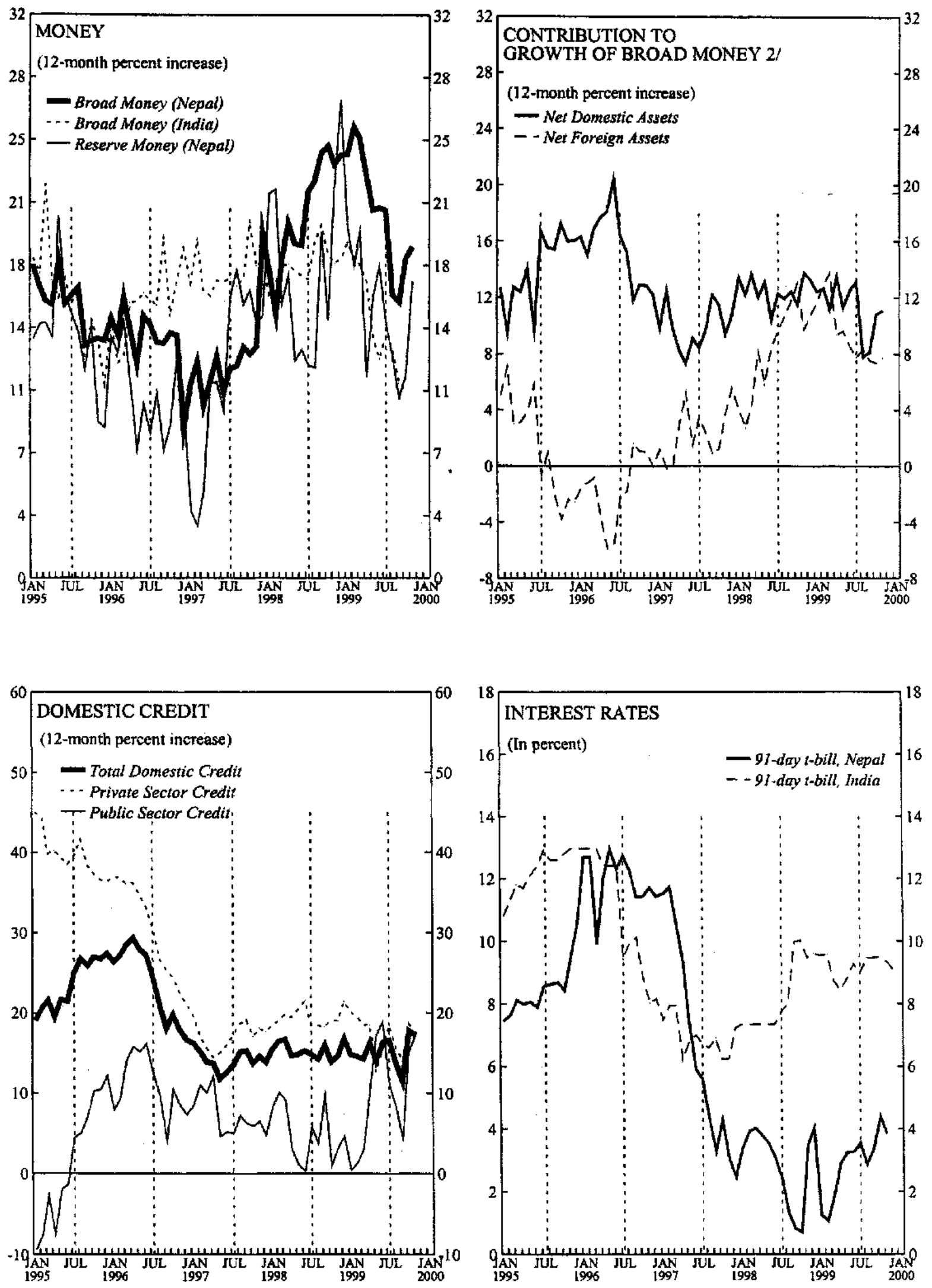

Sources: Data provided by the Nepalese authorities; and staff estimates.

1/ Beginning of fiscal year is indicated by a dotted line.

2/ Adjusted for valuation effects of exchange rate changes; in percent of broad money at beginning of period. 
Narrow money increased owing to a rise in currency. The extra demand for cash reflected the preparations for the religious festivities that took place in November.

\section{The pace of credit to the private sector increased only marginally to around} $181 / 2$ percent in 1998/99. Loan recovery operations led by the 2 largest banks, Rastriya Banijya Bank (RBB) and Nepal Bank Limited (NBL), and the slowdown of the economy continued to limit the expansion of credit to the private sector. In addition to the lack of viable projects in general, the decline in imports reduced the demand for import credits. Insurgencies in the rural areas also prevented commercial banks from seeking new opportunities in the hills. Credit expansion to the private sector accelerated in early $1999 / 2000$ to $191 / 4$ percent.

53. There was a substantial acceleration of growth in eredit to the public sector in 1998/99, continuing in early 1999/2000. In an effort to reduce the government's reliance on central bank financing, the NRB converted Nrs $6 \frac{1 / 4}{4}$ billion of central government overdraft into treasury bills in March 1999, of which Nrs 31/2 billion had been sold in the market by mid-December. However, in the first half of 1999/2000 the government's overdraft from the NRB was generally well above the legal ceiling of Nrs 1 billion set in the Public Debt Realization Act.24 The authorities anticipate that the outstanding converted treasury bills will be rolled over when they mature in March 2000.

54. Nominal commercial bank interest rates generally continued to fall in $1998 / 99$, leading to sharply negative real rates. The limited demand for bank credits in the private sector, and NRB's policies, continued to have the effect of bringing down commercial bank interest rates. Though at a slower pace than lending rates, deposit rates followed the declining trend, gradually widening the difference with the corresponding rates in India, raising concerns of capital flight. Consequently, the spread between commercial banks' deposit and lending rates fell during the year. ${ }^{25}$ However, the private banks were able to maintain healthy profit margins, because of the high spread required by the two troubled large banks.

55. Interest rates on treasury bills rebounded to around 4 percent in early 2000 after plunging to $1 / 2$ percent in October 1998 (91-day bills). Nevertheless, the difference between rates in India and Nepal continued to be considerable. The increasing excess liquidity and the reluctance on the part of the government to allow a substantial rise in the treasury bill rate, for fear of increasing its debt burden, kept downward pressure on the rates. However, in December 1999, the NRB sold some of its remaining overdraft-converted treasury bills, raising the yields on treasury bills.

\footnotetext{
${ }^{24}$ The limit is only binding at the end of each fiscal year.

${ }^{25} \mathrm{~A}$ simple calculation using unweighted mid-rates shows the average spread declining from 8 percent to $6 \frac{1}{2}$ percent in the course of $1998 / 99$.
} 


\section{Financial System Developments}

56. During the 1990's Nepal made significant progress in developing its financial sector. From a situation with only two state-owned commercial banks at the beginning of the decade, at end-1999 there were 13 commercial banks, two development banks, five regional development banks, one postal savings bank, 45 finance companies, 29 nongovernment cooperative societies involved in limited banking activity, and 30 nongovernment macrocredit institutions.

57. Although the number of institutions increased dramatically, the financial sector continues to be highly segmented. This phenomenon is, in part, a consequence of the state of financial sector legislation that has been geared toward fragmentation rather than integration. By legally allowing a large number of different categories of financial institutions, but not allowing mergers and acquisitions between categories, the dynamic elements of increasing competition and corporate restructuring have not materialized. This explains, in part, why the two major banks continue to dominate the commercial banking sector despite the sharp increase in the number of institutions. In mid-1999, RBB and NBL reported a combined share of 86 percent of commercial bank branches; 61 percent of total lending; and 52 percent of total deposits in the banking system.

58. Most of the remaining 11 commercial banks are majority foreign-owned and subject to somewhat more restrictive regulation. Nine are joint-venture banks with 50 percent foreign shareholding, and two institutions are privately-owned domestic banks. The local shareholding in joint-venture banks typically consists of local financial institutions, including development banks and the Employers' Provident Fund. The joint-venture banks have generally specialized in trade finance but have also, since the mid-1990s, expanded their activities into the industrial sector, tourism, and transport sectors. These institutions tend to perform well.

59. The government retains considerable influence over financial sector activities, including through its ownership of key financial institutions such as RBB, Agricultural Development Bank of Nepal (ADBN), and Nepal Industrial Development Corporation (NIDC), and-until recently-NBL. Special regulations affecting joint-venture banks also provide the NRB and the Ministry of Finance with unusual leeway in influencing banking institutions. Current rules require that the foreign bank enter a so-called "technical service agreement" with the banking supervisors, including imposing a limit on the number of expatriate managerial staff allowed to operate in Nepal.

\section{Key Issues in the Financial Sector}

60. The financial sector remains weak and unable to provide adequate financial intermediation, and its development is held back by the deep-rooted financial difficulties of RBB and NBL. In mid-1999, RBB accounted for more than 30 percent of 
total bank assets, and nonperforming loans amounted to at least 25 percent. ${ }^{26}$ In absolute terms, this represented the largest stock of nonperforming assets in Nepal. In some cases, loans have not been serviced for the last 15 years.

61. Nonperforming loans appear to be on the rise for a number of reasons despite attempts in recent years to improve debt recovery and more cautious lending practices. One reason is the lack of debt servicing that occurred during the election period early in 1999. Another contributing reason was the fall in property values that has taken place since mid-1999. This has left RBB and NBL as the two largest owners of real estate in Nepal, partially as a result of reclaiming collateral on defaulted loans. Moreover, NPLs increased as a result of more rigorous classification of loan portfolios.

62. Financial sector weaknesses also stem from deficiencies in the functions of the NRB as supervisor for licensed deposit-taking financial institutions. Among these, six main areas have been identified as of particular importance: (i) absence of operational independence, (ii) fragmentation of supervisory responsibilities, (iii) internal line-of-authority problems, (iv) difficulties in enforcement of corrective actions, (v) lack of legal immunity for inspectors/supervisors, (vi) incomplete supervision of "fit-and-proper" domestic bank managers.

\section{Financial Sector Reform Strategy}

63. While there has been progress in expanding and developing the financial sector during the 1990s, much remains to be done towards the establishment of an effective financial services sector. The main objective of the financial sector reform program is to provide a foundation for a sound, market-oriented, competitive system which would underpin macroeconomic stability and private sector-led growth. Discussions on an appropriate strategy for financial sector reform have taken place with the Fund, World Bank, the AsDB, and various other donors and private organizations. The NRB recently drafted a sectoral reform strategy aiming to:

- Implement restructuring plans for the financially-troubled major banks. The reform changes to RBB, NBL, ADBN and NIDC could entail replacing management, introducing improved credit control mechanisms, and the closure of unprofitable branches. Both RBB and NBL are making attempts to improve loan recovery. ${ }^{27}$

\footnotetext{
${ }^{26}$ Based on official reporting. Studies by outside agencies suggest the position is much worse. Of note, the main Kathmandu branch has been identified as the major source of problems of bad loans and poor accounting.

${ }^{27} \mathrm{RBB}$ plans to call on government guarantees for defaulted loans, although necessary funds have not yet been allocated in the budget. NBL has already called on some government guarantees.
} 
- Enhance the legal and regulatory framework covering the financial sector. Legislation is to be modernized and regulations regarding deposit-taking institutions improved. A general review is to be carried out with a timetable of amendments of current legislation with a view to reducing segmentation and fragmentation.

- Strengthen NRB and its supervisory function, and limit its role to central banking In this connection, an on-going analysis of the supervisory and regulatory functions of the NRB by an external consultant financed by the World Bank, aims to lay the foundation for a sounder monitoring of the banking system. ${ }^{28}$ Box 3 summarizes the staff's assessment of the key issues.

- Improve regulation of nonbank deposit-taking institutions in a manner similar to that of banks. Market-based competition would be increased through deregulation. A new banking law based on international best practices is being planned in addition to a new NRB Act, enhancing autonomy and accountability. In addition, a Financial Institutions Insolvency Act will be prepared.

- Strengthen the legislative and institutional framework for loan recovery. This includes improving accounting and auditing practices of financial institutions, and completing audits for banks' financial accounts by internationally recognized firms.

\section{Fiscal DeVelopments ${ }^{29}$}

\section{In recent years, fiscal} performance has been characterized by low and declining revenue to GDP ratios, increasing regular expenditure, and sizeable underspending of development expenditure. The overall deficit before grants has been maintained within the range of 6-7 percent of GDP and public savings have been negligible, imposing a constraint on capital spending (Figure 9). Foreign grants have financed the deficit by about 2 percent of GDP in recent years, but

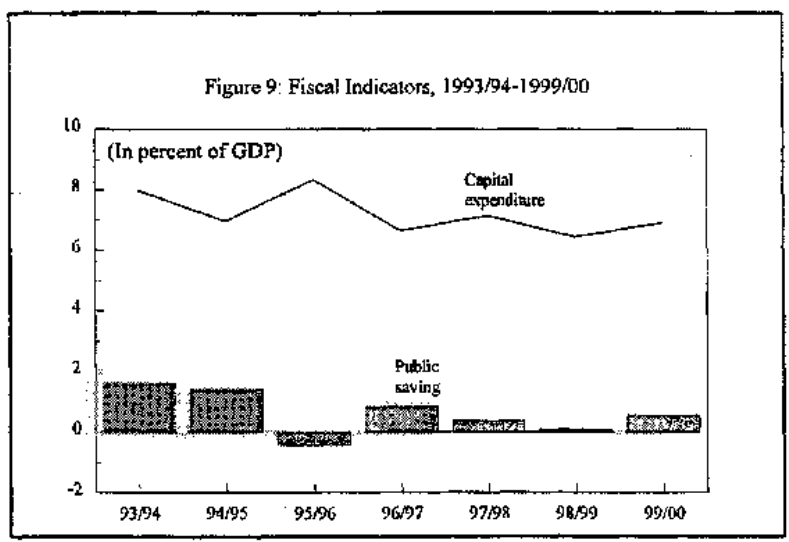
domestic bank financing has been on the rise. A small, but growing share of government operations is excluded from the budget as specific charges are earmarked to special funds. Local government budgets are not subject to parliamentary scrutiny during the annual budget exercise, except for direct transfers from the central government.

\footnotetext{
${ }^{28}$ The on-site examinations will provide a more accurate picture of the health of commercial banks and other important deposit taking institutions.
}

${ }^{29}$ See Appendix Tables 28-32. 


\section{Box 3. Banking Supervision: Areas to Be Strengthened at NRB}

\section{Weaknesses}

Absence of operational independence. NRB's autonomy remains limited, subject to the influence of the Ministry of Finance. This affects the central bank operations in general and particularly with respect to its supervisory operations vis-à-vis state-owned commercial and development banks.

Fragmentation of supervisory responsibilities. The traditional functions of a financial supervisory authority-preparation of relevant financial legislation and prudential regulations, licensing and delicensing of institutions, on-site inspections and off-site examinations-are typically managed together. However, these functions are divided between four different departments of the NRB. Such a structure does not promote the high degree of integration necessary for effective supervision.

Internal line-of-authority problems. The existing hierarchical structure, whereby control is concentrated at the level of deputy governors, gives limited authority to inspectors and supervisors. Completed examination reports are often not acted upon at the higher level.

Difficulties in enforcement of corrective actions. If the report is acted upon, further contacts are typically handled at the higher levels with little communication reaching the inspectors/supervisors. This may prevent supervisors from following-up on recommended corrective actions.

Lack of legal immunity for inspectors/supervisors. The threat exists that an examiner can be personally sued in a court of law (and risk personal bankruptcy) by a supervised financial institution. Although no such cases have been reported recently, there have been cases earlier, making examiners cautious.

Incomplete supervision of "fit-and-proper" domestic bank managers. Prospective managers are only vetted, based on normal "fit-and-proper" criteria, when a Nepalese-owned institution is considered for a banking license. Once the license has been awarded, the examiners have no such authority.

Reform measures. Strengthening of NRB's supervisory capacities would entail:

- reorganization to provide for operational autonomy for the supervision function, unified under one deputy governor responsible to the NRB Board;

- an institutional development plan for supervision functions to develop its capabilities for staffing, training, on-site and off-site activities, enforcement action, data processing and disclosure and prudential regulations;

- functional collaboration between the four regulatory/supervisory departments;

- enhancement of its regulatory functions, including prudential regulations, accounting, and auditing practices;

- legal powers to implement the Core Principles;

- improvement in on-site and off-site supervision through staffing and training; and

- expansion of supervision of nonbank financial institutions, especially development banks. 


\section{A. Central Government Operations in 1998/99}

\section{The overall deficit before grants declined by $1 / 2$ percent of GDP in 1998/99}

partially offsetting the increase in the previous year. The deficit continued to be financed primarily by foreign aid. Public savings remained close to zero and the decline in the overall deficit mainly reflected a larger than usual shortfall in spending on development projects, as approval of the project portfolio was delayed in the beginning of the year (Figure 10).

\section{Revenue Developments}

66. Although revenue collection has significantly increased since the early 1990's, it remains low even when compared to other Asian countries (Table 3 ). Total revenue remains below 11 percent of GDP. Tax collection, which had remained at less than 9 percent of GDP, consistently below budget targets of $9 \frac{1}{2}-10$ percent of GDP, fell further, to $83 / 4$ percent of GDP. Non-tax revenue remained at the same level as in the previous year and fell far short of the budgeted 25 percent increase.

\begin{tabular}{|c|c|c|c|c|c|c|}
\hline \multicolumn{7}{|c|}{ Table 3. Nepal: Revenue Comparisons } \\
\hline & \multicolumn{4}{|c|}{ Nepal } & \multicolumn{2}{|c|}{$\begin{array}{l}\text { SAF/ESAF Countries } \\
\text { Latest year available }\end{array}$} \\
\hline & $\begin{array}{c}\text { Average } \\
90 / 91-92 / 93\end{array}$ & $\begin{array}{c}\text { Actual } \\
1997 / 98\end{array}$ & $\begin{array}{l}\text { Estimate } \\
1998 / 99\end{array}$ & $\begin{array}{c}\text { Budget } \\
1999 / 2000\end{array}$ & $\begin{array}{c}\text { Asian } \\
\text { Countries }\end{array}$ & $\begin{array}{c}\text { Median } \\
\text { 1/ Revenue }\end{array}$ \\
\hline & \multicolumn{6}{|c|}{ (In percent of GDP) } \\
\hline Total revenue & 8.6 & 10.7 & 10.1 & 11.1 & 15.4 & 16.9 \\
\hline Tax revenue & 6.7 & 8.7 & 8.2 & 9.1 & 12.9 & 14.2 \\
\hline \multicolumn{7}{|l|}{ Of which: On income, profits, } \\
\hline On domestic goods and services & 3.2 & 3.9 & 3.4 & 3.8 & 6.5 & 5.0 \\
\hline On international trade & 2.4 & 2.9 & 2.7 & 3.0 & 3.4 & 5.1 \\
\hline \multirow[t]{2}{*}{ Nontax revenue } & 1.3 & 1.9 & 1.9 & 2.0 & 2.5 & 2.7 \\
\hline & \multicolumn{6}{|c|}{ (In percent of total revenue) } \\
\hline Tax revenue & 78.3 & 81.9 & 81.3 & 82.1 & 83.8 & 84.0 \\
\hline $\begin{array}{l}\text { Of which: On income, profits, } \\
\text { and capital gains }\end{array}$ & 13.2 & 15.5 & 17.7 & 17.5 & 19.5 & 21.3 \\
\hline On domestic goods and services & 37.8 & 36.0 & 33.5 & 34.4 & 42.2 & 29.6 \\
\hline On international trade & 27.3 & 26.8 & 26.9 & 27.2 & 22.1 & 30.2 \\
\hline Nontax revenue & 15.7 & 18.1 & 18.7 & 17.9 & 16.2 & 16.0 \\
\hline
\end{tabular}


$-31-$

Figure 10: Fiscal Developments: Comparison of Budget Outturn, 1994/95-1998/99

(In percent of GDP)
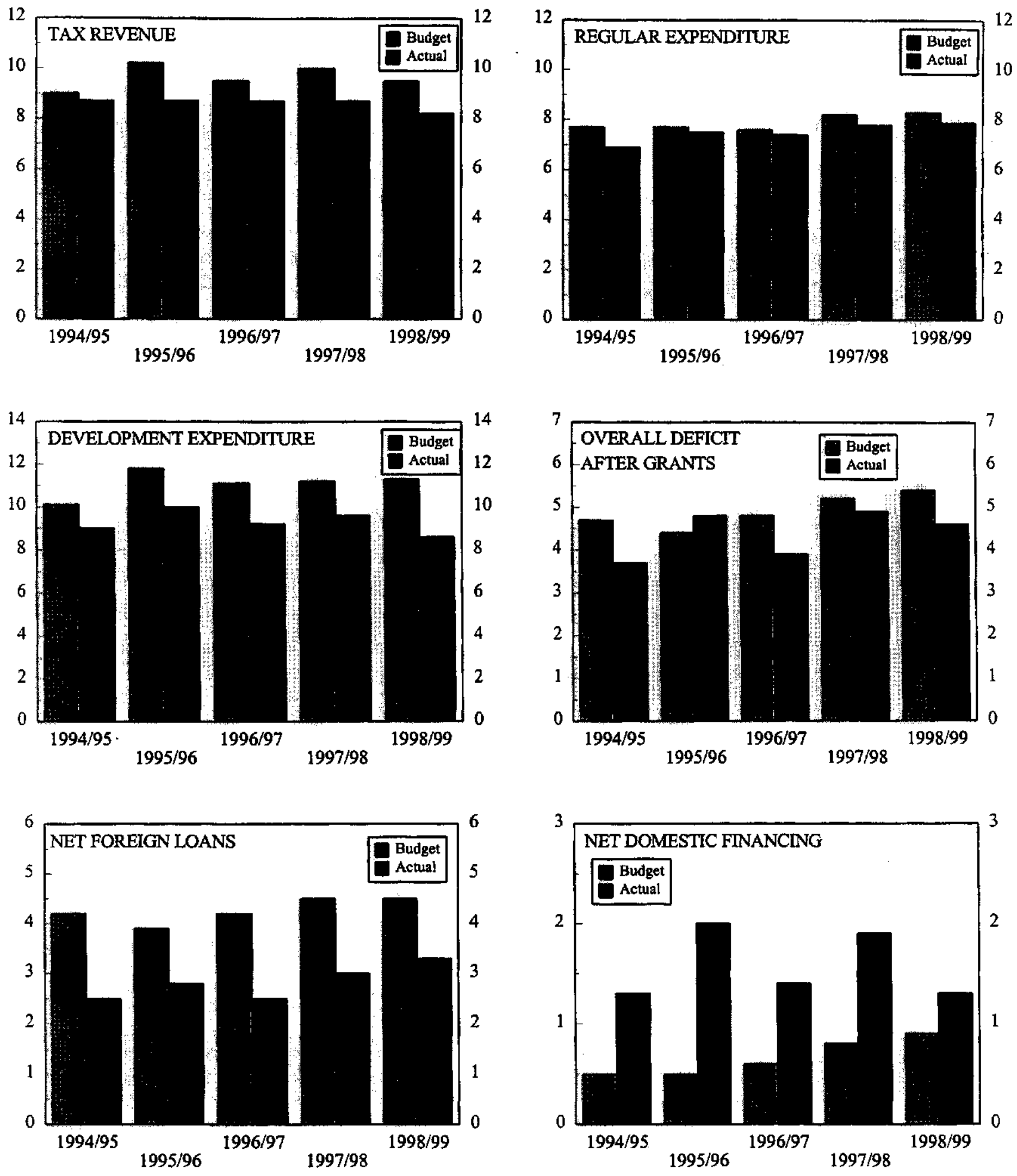

Source: Data provided by the Nepalese authorities. 
67. The shortfall in tax revenue was widespread, including VAT, excises, and property taxes. VAT compliance has remained very low and registration was slow to pick up. The threshold failed to capture many wholesalers and retailers. Continued slackness in real estate activity and weak enforcement of the house and land tax kept property taxes at low levels.

68. Revenue from trade taxes increased substantially, but remained below budgeted amounts. Export taxes increased by 74 percent as export grew by 32 percent. Import revenues also increased. Although imports declined in 1998/99, this was partially offset by the introduction of a new import duty rate of 40 percent on a substantial share of imports. The shortfall in import taxes in 1998/99 compared to the budget is explained by lower than projected imports and the undervaluation of dutiable imports.

69. Taxes on income and profits, however, well-exceeded the budgeted amounts, and reached $1 \frac{3 / 4}{4}$ percent of GDP, partly offsetting the sizeable shortfalls in other categories of taxes. This improvement reflects the impact of a number of policy measures designed to broaden the tax base and control leakage, including raising the tax exemption limit, adjusting the rate for the middle income group; and introducing tax surcharges for non-residents and higher income earners. Higher collections also reflect the strengthening of tax administration under on-going donor-supported projects as outlined in Box 4.

\section{Expenditure Developments}

\section{Total expenditure declined to $16^{1 / 2}$ percent of GDP in $1998 / 99$ reflecting lower} development spending compared with 1997/98. Total spending was below budget projections by 3 percent of GDP due to shortfalls in development spending. The share of regular spending in total expenditure increased reflecting an expanding wage bill, which accounted for over one third of total expenditure in 1998/99, and a number of extraordinary expenditures (Figure 11). The civil service labor force increased by 5 percent in 1998/99 due to employment of a large number in health-related projects. Nevertheless, wage payments were about 5 percent below target due to unfilled positions. Extraordinary expenditures included security - and election-related spending and the cost of South Asian Athletic Federation (SAAF) games. These higher spending items in 1998/99 were partially offset by lower subsidies on fertilizers.

71. Development expenditure fell short of budget targets in $1998 / 99$ by $13 / 4$ percent of GDP reflecting weak project implementation and start-up delays related to late budget formulation. Development spending was 1 percent of GDP lower than in the previous year. The shortfall was the greatest in social sectors; total spending on education and health has 


\section{Box 4. Recent Tax Reforms and Key Measures to Strengthen Administration}

Revenue collections are adversely affected by weaknesses in the tax system and in tax administration. There are frequent changes in the tax system and a large number of exemptions (Apprendix Table 32 provides a tax summary). Administrative problems include insufficient staffing and training, low pay and poor incentives, as well as inadequate transportation and communication infrastructure. Several tax reform and administration measures have been introduced, with substantial donor assistance. Nevertheless, further assistance is needed together with greater government commitment to enforce tax measures.

\section{General}

The Ministry of Finance is developing an integrated and computerized system of taxpayer registration, audit, and research that is intended to improve the operations of the VAT and income tax administration. The Kathmandu Taxpayer Service Center was established for common registration and to begin a program of joint audit and research. The center will be issuing Permanent Identification Numbers (PINs) that will be jointly used for VAT and income taxation. This is to be expanded to other regions. There is a plan to merge the VAT and Tax Department in the future. Computerization of tax offices has progressed slowly due to financing and implementation problems. When complete, it will facilitate issuance of PINs and establishment of the profiles of tax payers in the 10 offices to be initially computerized.

\section{Customs administration}

An invoice valuation system replaced the book-value system in order to improve collections, but there has been little improvement due mainly to the absence of invoices for a large proportion of transactions as well as poor governance, and inadequate enforcement. The growing barter trade with Tibet poses an additional problem in terms of valuation. Enforcement is also complicated by the difficulty of monitoring the long borders with India and Tibet. Post-clearance audits are intended to improve the effectiveness of the valuation system but these have not yet been initiated.

\section{VAT administration}

The VAT was first introduced in November 1997, but resistance from the business community caused delays in its implementation until August 1998. Initially, the major problem was non-registration of large wholesalers, high threshold and the valuation system in customs. The 1999/2000 budget introduced a number of changes to address these problems:

- the threshold has been reduced to Nrs 2 million from Nrs 4.5 million.

- the number of registrants has been rising as registration became a requirement for participation in government contracts and to be eligible for exports-related refunds. However, most new registrants are exempt from VAT payment and the surge has strained VAT resources.

At this time staffing and enforcement are the main problems. Because of staffing problems, there has been a growing backlog of unprocessed tax returns. Moreover, staffing shortages have delayed field visits and audits needed to enforce compliance.

\section{Income tax administration}

A number of measures were recently introduced to broaden the tax base and improve income tax collections, including: (i) assessing taxes on current year's income; (ii) presumptive taxation for taxpayers below the limit of Nrs 10 million; (iii) monitoring and review of the tax self assessment scheme.

Other administrative measures comprise:

- Tax related appeals cases are to be resolved within one year.

- Publication of a comprehensive tax manual.

- Conducting a survey intended to bring another 25,000 taxpayers into the tax net. 
Figure 11: Composition of Revenue and Expenditure, 1998/99

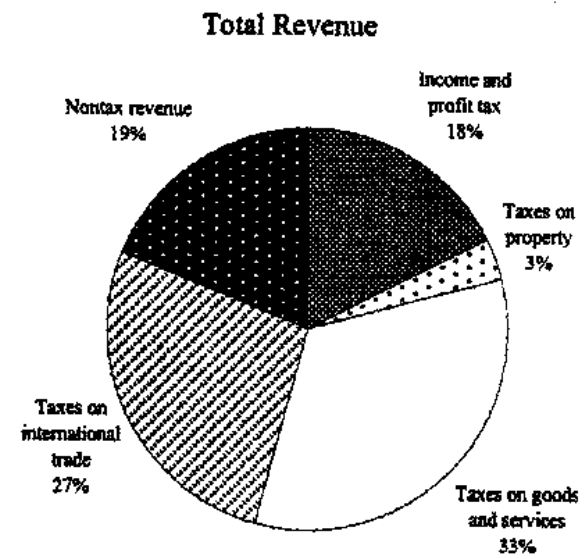

Expenditure by Economic Classification

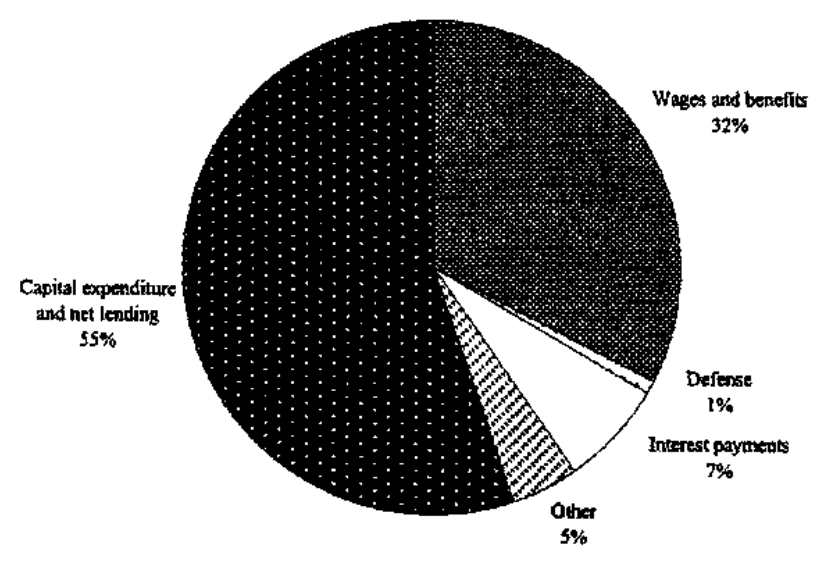

Expenditure by Functional Classification

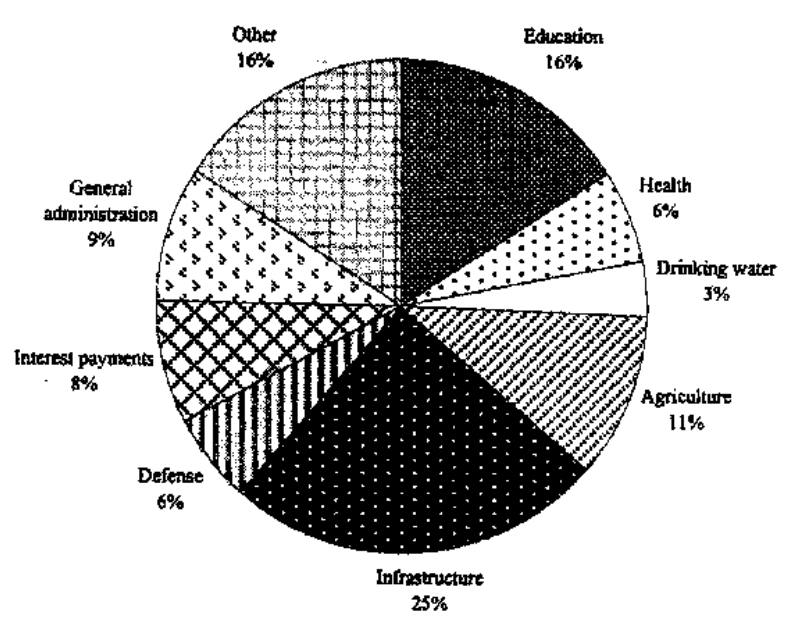

Source: Data provided by the Nepalese authorities. 
averaged less than 4 percent of GDP since 1990, similar to levels in other Asian countries but well below what is needed to improve social indicators (Table 4).

\begin{tabular}{|c|c|c|c|c|c|c|}
\hline & \multicolumn{4}{|c|}{ Nepal } & \multicolumn{2}{|c|}{$\begin{array}{l}\text { SAF/ESAF Countries } \\
\text { Latest year available }\end{array}$} \\
\hline & $\begin{array}{c}\text { Average } \\
90 / 91-92 / 93\end{array}$ & $\begin{array}{l}\text { Actual } \\
1997 / 98\end{array}$ & $\begin{array}{l}\text { Estimate } \\
1998 / 99\end{array}$ & $\begin{array}{c}\text { Budget } \\
1999 / 2000\end{array}$ & $\begin{array}{l}\text { Asian } \\
\text { Countries } 1 /\end{array}$ & $\begin{array}{l}\text { Median } \\
\text { Revenuē }\end{array}$ \\
\hline & \multicolumn{6}{|c|}{ (In percent of GDP) } \\
\hline General Government expenditures $2 /$ & 15.3 & 17.4 & 16.5 & 18.1 & 21.6 & 23.9 \\
\hline Current expenditure & 5.7 & 7.8 & 7.9 & 7.7 & 14.0 & 15.9 \\
\hline Capital expenditure & 9.6 & 9.6 & 8.6 & 10.4 & 7.6 & 7.9 \\
\hline \multicolumn{7}{|l|}{ By functional classification } \\
\hline Defense & 1.0 & 0.9 & 0.9 & 0.9 & 3.7 & 2.3 \\
\hline Education & 2.4 & 2.7 & 2.4 & 2.7 & 2.2 & 4.3 \\
\hline Health & 0.6 & 1.3 & 1.2 & 1.2 & 1.1 & 1.9 \\
\hline \multirow[t]{2}{*}{ Other } & 11.3 & 12.5 & 12.0 & 13.3 & 14.6 & 15.3 \\
\hline & \multicolumn{6}{|c|}{ (In percent of total expenditure) } \\
\hline \multicolumn{7}{|l|}{ General Government expenditures 2/ } \\
\hline Current expenditure & 37.3 & 44.6 & 47.8 & 42.7 & 64.8 & 66.5 \\
\hline Capital expenditure & 62.7 & 55.4 & 52.2 & 57.3 & 35.2 & 33.1 \\
\hline \multicolumn{7}{|l|}{ By functional classification } \\
\hline Defense & 6.5 & 5.1 & 5.0 & 5.1 & 17.1 & 9.6 \\
\hline Education & 15.7 & 15.4 & 14.0 & 14.8 & 10.2 & 18.1 \\
\hline Health & 3.9 & 7.3 & 5.5 & 6.4 & 4.9 & 8.1 \\
\hline Other & 73.9 & 72.2 & 75.5 & 73.7 & 67.8 & 64.2 \\
\hline
\end{tabular}

\section{Financing}

72. Nepal relies heavily on foreign loans obtained on highly concessional terms to finance infrastructure and social development projects. Concessional foreign loans have been underutilized because of delays in project implementation. Net domestic financing has been consistently higher than budgeted; amounting to $1 \frac{1}{2}$ percent of GDP in 1998/991 percent of GDP higher than budgeted. The overdraft facility from the central bank has been increasingly used in lieu of issuance of treasury bills to finance budgetary operations. The absence of a borrowing strategy and limits imposed on the gross amount of treasury bills that can be issued within the year have constrained the ability of the Ministry of Finance to issue debt. Total domestic debt is relatively low at Nrs 48 billion, amounting to 14 percent of GDP at end 1998/99. Total external public debt is also relatively low, amounting to about 50 percent of GDP. The debt service is in the range of 5-6 percent of GDP and there has been 
no formal debt write-off. Japan, the main bilateral creditor, is providing debt relief by refunding the amount of debt service paid.

\section{B. Central Government Budget for 1999/2000}

73. The 1999/2000 budget announced on July 11, 1999 aimed to increase public savings by $1 / 2$ percent of GDP and increase tax revenues by nearly 1 percent of GDP relative to the 1998/99 outcome. The overall deficit (before grants) was to be budgeted to increase by $1 / 2$ percent of GDP to 7 percent of GDP. Higher taxes were to be achieved mainly through improved VAT implementation and higher import duty collection. The number of VAT registrants was to increase and field visits and audits were expected to improve collections.

74. The budget also envisaged containment of regular spending to less than the 1999/2000 levels in GDP terms and a substantial increase in development spending. The increase in development spending, by nearly 2 percent of GDP, was to be financed through a substantial increase in foreign grant receipts-significantly higher than in recent years.

75. As the fiscal position strengthened, net domestic borrowing was to be reduced to 1 percent of GDP in 1999/2000. External financing from foreign grants and loans was expected to increase, based on pipeline aid commitments and ongoing discussions with donors.

\section{Latest Developments}

76. Preliminary data for the first five months of 1998/99 show that the fiscal deficit was substantially more than in the same period of $1997 / 98$, due to higher development spending. Moreover, with slower disbursement of foreign loans and grants, there has been a much greater dependence on domestic financing, mainly through the overdraft facility with the central bank.

77. Tax collections were higher than amounts collected for the same period last year. Income tax collections were running higher than targeted in the budget, while VAT and import taxes collections appeared on target. However, emerging administrative problems in both these areas pose a threat to the continuation of tax collections at the same pace.

Although customs revenues are on target, they have not risen in proportion to the increases in import values. Moreover, the post clearance audits have not yet begun and little is being collected from the reportedly growing trade volumes at the Tibet border, ostensibly due to lack of invoice documentation of barter trade. Also, although total VAT collections are only slightly below targets, this is partly due to one-off factors, including a discounted up front payment of VAT on stocks that will result in lower collections in later months. Moreover, collections of VAT at customs posts is higher than expected, possibly due to higher oil prices and higher than anticipated imports, while domestic VAT collection is lagging well below targets. Although registrations have increased substantially, most are non-VAT payers and reported transactions have not increased as expected. Staff vacancies are the main problem 
constraining administration and enforcement efforts. The Ministry of Finance recognizes the need to fill these positions, but appointments have been delayed.

78. Current expenditures are well above targets and running much higher than the same period last year. Unbudgeted spending overruns stem from police expenses, protocol expenses, higher utility costs, and the impact of the civil service allowance. These overruns are now estimated at well above the contingency amount of Nrs 350 million.

79. Development spending is also running much higher than the same period lasit year although it is still well below target. In the first five months of 1999/2000, development spending (based on data on the cash-financed component of spending) was higher than in the past year due to a change in regulations that allows disbursement of the local component of project funds prior to disbursement of the foreign grant component. However, the overrun in current spending could lead to some delay in development projects later in the year.

\section{Local Government and Off-Budgetary Accounts}

80. The central government accounts do not fully represent the totality of fiscal operations as they do not include the self-financed activities of the local government offices and a small but growing number of earmarked taxes and fees. Estimates of offbudget activity discussed below are illustrative, and are intended to give a flavor of the overall fiscal picture; and as such, they should be treated with caution.

81. There are three levels of local government with varying degrees of revenueraising abilities. Information on local government finance is not currently compiled and will be facilitated by the establishment of regional offices for the Ministry of Finance and computerization of the regional treasury offices, which is currently at an early stage. There are 75 district development committees (DDCs), 58 municipalities and 3,913 village development committees (VDCs).

\section{Local Government}

82. There have been a number of recent changes in legislation governing local government finance, but the main changes are still under consideration. In particular, a revenue sharing arrangement of some central government taxes is under consideration which would allow local governments greater independence in their operations. ${ }^{30}$ Greater independence is expected to enhance community participation, thereby improving the management and governance of rural human resource and infrastructure projects and contributing to the improvement of social indicators and future income generation.

\footnotetext{
${ }^{30}$ The Ministry of Local Development has been preparing a strategy for local finance and a GTZ-funded project is supporting this effort by documenting the operations of municipalities. No efforts are being made to document the operations of VDCs and DDCs.
} 
83. Total transfers from the central to local government are estimated at around Nrs 23/4 billion for 1998/99 with the bulk going to the DDCs, as shown in Box 5. Transfers $1999 / 2000$ are expected to rise in 1998/99 by an additional Nrs 100-200 million to cover the expected decline in local government revenue, following the abolition of the octroi tax in 1998/99. ${ }^{31}$ In 1996, VDCs were authorized to collect a land tax and retain about 75 percent, while transferring 25 percent to their respective DDCs. While no figures are available on the revenue from the land tax, it is believed to be relatively small, accounting for a small fraction of local government income. In contrast, municipalities raise the bulk of their income from local revenues, which in 1999/2000 amounted to Nrs 1.6 billion.

\section{Off-Budget Accounts}

84. Under the Finance Act, Parliament has recently authorized the collection of a number of taxes, fees and charges that are not deposited into the account of the Treasury nor included in the overall annual budget presented for parliamentary approval. Information is not available on the size of these accounts, but efforts are being made to improve monitoring of such funds and to compile more comprehensive accounts. Some of these funds were taken out of the budget, thereby contributing to the reduction in tax revenues in 1998/99 and in the current fiscal year. For example, although the hotel tax was replaced by the VAT, a new Tourism Development Fee was introduced to collect income for the Tourism Development Board. The Air Flight Tax was replaced by an Air Flight Service Charge in July 1999, with receipts collected and retained by the Civil Aviation Authority. Other funds have been created for special temporary purposes. For example, the SAAF Games that took place in 1999 were to be primarily funded from a surcharge (on imports at the ports of entry). ${ }^{32}$

\section{ViI. Public Sector Enterprises and Privatization ${ }^{33}$}

85. The net income position of non-financial enterprises deteriorated in 1998/99. If the profits of the Nepal Telecommunications Corporation (NTC) are excluded, the overall position of non-financial enterprises recorded losses, as in the previous two years (Table 35). Fourteen out of the 34 reporting enterprises recorded losses. To cover these losses and provide for capital requirements, budgetary transfers of over Nrs 2 billion (equivalent to 6 percent of government revenue) have been required in the last three years. These large losses reflect deep-seated administrative problems, including the lack of financial and operational autonomy, and increased private sector competition. The three largest loss makers in 1998/99 were the Nepal Food Company (NFC), the AIC and the Udayapur

\footnotetext{
${ }^{31}$ The octroi was levied by municipalities on the transit passage of goods and vehicles.

${ }^{32}$ Because costs have not yet been covered, this surcharge was still being collected in December 1999.

${ }^{33}$ See Appendix Table 33-35.
} 


\section{Box 5. Constructing Comprehensive Government Accounts}

Analysis of the fiscal stance, and of the tax burden and composition of expenditures, is hampered by the timeliness and presentation of fiscal statistics. Currently, the presentation of fiscal accounts does not conform to GFS guidelines in a number of important areas. The government does not produce periodic data on the economic classification of expenditure, and when these are provided, they involve several misclassifications (e.g., teacher salaries are included under subsidies and transfers). Moreover, the accounts are not comprehensive, limited to the central government budget. This is more important as there has been a shift

\begin{tabular}{|c|c|c|c|}
\hline \multicolumn{4}{|c|}{$\begin{array}{l}\text { Estimate of General Government Accounts } 1 / \\
\text { (In billions of Nepalese rupees) }\end{array}$} \\
\hline & $1997 / 98$ & $1998 / 99$ & $\begin{array}{c}1999 / 2000 \\
\text { Budget }\end{array}$ \\
\hline $\begin{array}{l}\text { 1. Central government } \\
\text { Overall balance after grants } \\
\text { Total revenue and grants } \\
\text { Total revenue } \\
\text { Grants } \\
\text { Total expenditure } \\
\text { Current expenditure } \\
\text { Wages } 2 / \\
\text { Capital expenditure } \\
\text { Lending minus repayments }\end{array}$ & $\begin{array}{r}-14.5 \\
37.1 \\
31.7 \\
5.4 \\
51.6 \\
24.3 \\
19.2 \\
27.3 \\
-1.1\end{array}$ & $\begin{array}{r}-16.0 \\
40.8 \\
34.9 \\
5.9 \\
56.7 \\
28.4 \\
20.6 \\
28.3 \\
-2.1\end{array}$ & $\begin{array}{r}-18.1 \\
50.9 \\
42.2 \\
8.7 \\
68.9 \\
31.0 \\
22.5 \\
37.9 \\
-2.3\end{array}$ \\
\hline $\begin{array}{l}\text { 2. Local government balance } 3 / \\
\text { Total revenue } \\
\text { Local government tax receipts } \\
\text { Octroi } 4 / \\
\text { Local development tax } 4 / \\
\text { Local cigarette tax } \\
\text { Urban house and land revenue } \\
\text { Other tax receipts } 5 / \\
\text { Transfers from central goverument } \\
\text { Transfers to DDCs } \\
\text { Transfers to municipalities } \\
\text { Transfers to VDCs } \\
\text { Transfer to cover shortfall in tax receipts } \\
\text { Direct grants or loans } \\
\text { Total expenditure }\end{array}$ & $\begin{array}{l}0.4 \\
5.2 \\
2.5 \\
2.0 \\
0.0 \\
0.3 \\
0.1 \\
0.1 \\
2.7 \\
1.9 \\
0.1 \\
0.6 \\
0.0 \\
0.0 \\
4.8\end{array}$ & $\begin{array}{l}0.1 \\
5.0 \\
2.3 \\
2.0 \\
0.0 \\
0.1 \\
0.1 \\
0.1 \\
2.8 \\
2.0 \\
0.1 \\
0.7 \\
0.0 \\
0.0 \\
4.9\end{array}$ & $\begin{array}{r}-0.4 \\
4.2 \\
1.2 \\
0.4 \\
0.3 \\
0.1 \\
0.1 \\
0.3 \\
3.0 \\
2.0 \\
0.2 \\
0.7 \\
0.2 \\
0.0 \\
4.6\end{array}$ \\
\hline $\begin{array}{l}\text { 3. Extra budgetary funds } 3 / 6 / \\
\text { Estimated balance } \\
\text { Total revenue } \\
\text { Of which: Earmarked taxes/fees } \\
\quad \text { Transfers from central government } \\
\text { Total expenditure }\end{array}$ & $\begin{array}{r}-0.1 \\
0.0 \\
0.0 \\
0.0 \\
0.1\end{array}$ & $\begin{array}{l}0.0 \\
0.4 \\
0.3 \\
0.1 \\
0.5\end{array}$ & $\begin{array}{l}0.3 \\
1.0 \\
0.7 \\
0.1 \\
0.7\end{array}$ \\
\hline $\begin{array}{l}\text { Total revenue adjusted for transfers } \\
\text { Of which: Off-budget revenue } \\
\text { Total expenditure adjusted for transfers } \\
\text { Of which: Off-budget expenditure } \\
\text { Adjusted total balance after grants } \\
\text { (As percent of GDP) }\end{array}$ & $\begin{array}{r}34.1 \\
2.5 \\
53.7 \\
2.1 \\
-14.2 \\
-4.8\end{array}$ & $\begin{array}{r}37.5 \\
2.6 \\
59.3 \\
2.6 \\
-15.9 \\
-4.6\end{array}$ & $\begin{array}{r}44.3 \\
2.1 \\
71.2 \\
2.3 \\
-18.2 \\
-4.7\end{array}$ \\
\hline
\end{tabular}

1/ Only central government data was provided, other estimates (shown in italics) are for illustrative purposes.

2/ From regular and development expenditure and including allowances.

3/ Local government and off-budget funds cannot borrow domestically or externally. Small working balances can be carried over.

4/ Local development tax is 1.5 percent of non-aid imports from 1999/2000. Collections are expected to be lower than octroi receipts. Although the octroi was officially abolished in 1999, some transit fees are reportedly still being collected.

5/ Some taxes formerly collected by central government will be shared/transferred as of 1999/2000.

6/ Includes Fund for Airflight Service Charge, Tourism Development Fees, SAAF Games Fees, and Insurance Board Fees.

toward increased local autonomy for tax collection and expenditure allocation, and a number of special earmarked funds have recently emerged. The authorities could not provide data on the magnitude of these two items and their impact on the overall general government outcome. However, the Ministry of Finance considered the above plausible guesstimates and welcomed technical assistance from the Fund that would improve the coverage of fiscal accounts. 
Cement Factory, which together accounted for Nrs $12 \frac{1}{2}$ billion in losses (or $1 / 2$ percent of GDP), despite receiving substantial budget transfers.

\section{A. Public Enterprise Reform}

\section{Several large enterprises are preparing restructuring plans and/or privatization} strategies to cope with the increased competition and to alleviate the burden on the budget. Restructuring plans have begun for the AIC(fertilizer and seed transport to rural areas) and NFC (distribution of rice and other commodities in short supply). AIC is being split into a fertilizer and seed company. With the removal of fertilizer subsidies (see section $\mathrm{I}$ ) and increased private sector participation, the AIC and NFC are reducing their size and concentrating on delivery only to a few remote districts. The oil company (NOC), which had financial difficulties at higher international prices, registered a sizeable profit last year on account of the drop in oil prices relative to domestically set prices. Similar performance is expected in 1999/2000 and there are some discussions on establishing an oil price stabilization fund.

87. However, progress is slower in a number of other enterprises. RNAC is in need of new capital and new management, but its restructuring is on hold awaiting the completion of a study evaluating its privatization options. NTC has been a profit maker on account of its monopoly position but the opening of the sector to private sector competition will require it to adopt an aggressive strategic business plan. Company and government officials are discussing the findings of a recent study that evaluated its business activities and market value.

\section{B. Privatization Progress}

88. Having privatized 16 companies to date, the government has identified approximately one half of the $\mathbf{4 7}$ public enterprises to be prepared for privatization (listed in Table 35). These include three out of the eight financial enterprises and 22 out of the 34 nonfinancial public enterprises, mostly in manufacturing and services. The privatization proceeds will, for the most part, be used to cover the enterprises' outstanding liabilities. The remaining 22 enterprises that are not on the privatization list, include the 6 trading companies, the electricity and water utilities and 5 financial institutions.

89. There was virtually no progress in privatization in $1998 / 99$, although some steps have been taken in recent months. One of the previously leased companies, the Bhaktapur Brick Factory, was repossessed by the government as the lessee did not satisfactorily perform his management duties and ran the company into financial difficulties. The privatization program for 1998/99 was to focus on the privatization of five companies: Himal Cement, Nepal Tea Development Corporation, Butwal Power Company (BPC), NTC and RNAC. As noted above, privatization strategies are still under discussion for the last two. Offers and terms of bids for the Himal Cement Company were deemed unsatisfactory and the Ministries of Finance and Industry are considering an alternative privatization proposal. Similar problems were encountered with the bids received for the Tea Corporation and for the $\mathrm{BPC}$. The first preferred bid for the Tea Corporation could not meet the financial obligations due to exchange restrictions imposed in India. Negotiations were shifted to the second bidder, and discussions are now focusing on severance pay for administrative staff to be made redundant. All estate workers are to be retained. As for the Butwal Power Company, there has been pressure to repeat the bidding process. 
Table 1. Nepal: Nominal Gross Domestic Product by Sector, 1994/95-1998/99

\begin{tabular}{|c|c|c|c|c|c|}
\hline & $1994 / 95$ & $1995 / 96$ & $1996 / 97$ & $1997 / 98$ & $\begin{array}{r}\text { Est. } \\
1998 / 99\end{array}$ \\
\hline & \multicolumn{5}{|c|}{ (In billions of Nepalese nupees, at current prices) } \\
\hline Agriculture, fisheries, and forestry & 85.6 & 96.9 & 108.8 & 112.5 & 129.6 \\
\hline Manufacturing & 19.6 & 22.5 & 24.8 & 26.6 & 31.8 \\
\hline Construction & 23.1 & 26.1 & 29.3 & 29.0 & 33.5 \\
\hline Electricity and water & 2.9 & 3.6 & 4.5 & 4.5 & 5.3 \\
\hline Mining and quarrying & 1.1 & 1.3 & 1.5 & 1.5 & 1.8 \\
\hline Financial and real estate & 20.5 & 23.5 & 27.2 & 29.7 & 35.1 \\
\hline Community and social services & 18.9 & 21.3 & 23.7 & 25.9 & 29.9 \\
\hline Trade, restaurants, and hotels & 24.3 & 28.3 & 30.6 & 33.6 & 38.7 \\
\hline Transport and communications & 14.0 & 15.9 & 19.3 & 22.4 & 26.8 \\
\hline GDP at facter cost & 210.0 & 239.4 & 269.6 & 285.7 & 332.4 \\
\hline Agricultural GDP & 85.6 & 96.9 & 108.8 & 112.5 & 129.6 \\
\hline Non-agricultural GDP & 124.4 & 142.5 & 160.8 & 173.2 & 202.8 \\
\hline Value of imputed banking services & 5.1 & 5.9 & 7.0 & 7.9 & 9.5 \\
\hline Net indirect taxes & 14.3 & 15.5 & 18.0 & 18.7 & 22.0 \\
\hline \multirow[t]{2}{*}{ GDP at market prices } & 219.2 & 248.9 & 280.5 & 296.5 & 344.9 \\
\hline & \multicolumn{5}{|c|}{ (Percentage share in nominal GDP) } \\
\hline Agriculture, fisheries, and forestry & 40.8 & 40.5 & 40.4 & 39.4 & 39.0 \\
\hline Manufacturing & 9.3 & 9.4 & 9.2 & 9.3 & 9.6 \\
\hline Construction & 11.0 & 10.9 & 10.9 & 10.2 & 10.1 \\
\hline Electricity and water & 1.4 & 1.5 & 1.7 & 1.6 & 1.6 \\
\hline Mining and quarrying & 0.5 & 0.6 & 0.6 & 0.5 & 0.5 \\
\hline Financial and real estate & 9.8 & 9.8 & 10.1 & 10.4 & 10.6 \\
\hline Community and social services & 9.0 & 8.9 & 8.8 & 9.1 & 9.0 \\
\hline Trade, restaurants, and hotels & 11.6 & 11.8 & 11.3 & 11.8 & 11.6 \\
\hline Transport and communications & 6.7 & 6.6 & 7.2 & 7.8 & 8.1 \\
\hline Agricultural GDP at factor cost & 40.8 & 40.5 & 40.4 & 39.4 & 39.0 \\
\hline \multirow[t]{2}{*}{ Non-agricultural GDP at factor cost } & 59.2 & 59.5 & 59.6 & 60.6 & 61.0 \\
\hline & \multicolumn{5}{|c|}{ (Annual percentage change) } \\
\hline \multicolumn{6}{|l|}{ Memorandum items: } \\
\hline Deflator for GDP at market prices & 6.3 & 7.8 & 7.3 & 3.3 & 12.5 \\
\hline Agriculture-sector deflator & 6.5 & 8.4 & 7.8 & 2.3 & 12.5 \\
\hline Nonagriculture-sectors deflator & 6.4 & 7.4 & 7.3 & 3.7 & 12.5 \\
\hline
\end{tabular}

Sources: The Central Bureau of Statistics in Nepal and Nepal Rastra Bank. 
Table 2. Nepal: Real Gross Domestic Product by Sector, 1994/95-1998/99

\begin{tabular}{|c|c|c|c|c|c|}
\hline & $1994 / 95$ & $1995 / 96$ & $1996 / 97$ & $1997 / 98$ & $\begin{array}{r}\text { Est. } \\
1998 / 99\end{array}$ \\
\hline & \multicolumn{4}{|c|}{ (In billions of Nepalese rupees, at $1984 / 85$ prices) } & - \\
\hline Agriculture, fisheries, and forestry & 29.9 & 31.2 & 32.5 & 32.9 & 33.6 \\
\hline Manufacturing & 6.0 & 6.6 & 7.0 & 7.2 & 7.6 \\
\hline Construction & 7.0 & 7.5 & 7.9 & 7.9 & 8.1 \\
\hline Electricity and water & 0.5 & 0.6 & 0.6 & 0.6 & 0.7 \\
\hline Mining and quarrying & 0.3 & 0.4 & 0.4 & 0.4 & 0.4 \\
\hline Financial and real estate & 7.0 & 7.5 & 7.9 & 8.3 & 8.7 \\
\hline Community and social services & 7.3 & 7.7 & 8.0 & 8.4 & 8.6 \\
\hline Trade, restaurants, and hotels & 8.1 & 8.4 & 8.8 & 9.2 & 9.5 \\
\hline Transport and communications & 5.5 & 5.8 & 6.3 & 6.6 & 7.1 \\
\hline GDP at factor cost & 71.7 & 75.8 & 79.4 & 81.6 & 84.3 \\
\hline Agricultural GDP & 29.9 & 31.2 & 32.5 & 32.9 & 33.6 \\
\hline Non-agricultural GDP & 41.8 & 44.5 & 46.9 & 48.7 & 50.7 \\
\hline Value of imputed banking services & 1.8 & 2.0 & 2.1 & 2.2 & 2.4 \\
\hline Net indirect taxes & 5.1 & 5.2 & 5.6 & 5.6 & 5.8 \\
\hline \multirow[t]{2}{*}{ GDP at market prices } & 75.0 & 79.0 & 83.0 & 84.9 & 87.8 \\
\hline & \multicolumn{4}{|c|}{ (Annual percentage change) } & \\
\hline Agriculture, fisheries, and forestry & -0.3 & 4.4 & 4.1 & 1.0 & 2.4 \\
\hline Manufacturing & 2.0 & 9.0 & 7.1 & 1.7 & 6.2 \\
\hline Construction & 5.2 & 6.6 & 6.1 & -0.9 & 2.7 \\
\hline Electricity and water & 12.0 & 19.4 & 1.7 & -2.2 & 5.7 \\
\hline Mining and quarrying & 3.5 & 13.1 & 6.7 & 1.3 & 3.7 \\
\hline Financial and real estate & 4.3 & 7.6 & 4.7 & 5.8 & 5.0 \\
\hline Community and social services & 4.8 & 6.0 & 3.3 & 5.9 & 2.5 \\
\hline Trade, restaurants, and hotels & 5.5 & 4.2 & 3.7 & 5.6 & 2.3 \\
\hline Transport and communications & 10.6 & 5.5 & 7.7 & 5.9 & 6.2 \\
\hline GDP at factor cost & 2.9 & 5.7 & 4.8 & 2.7 & 3.4 \\
\hline Agricultural GDP & -0.3 & 4.4 & 4.1 & 1.0 & 2.4 \\
\hline Non-agricultural GDP & 5.3 & 6.6 & 5.2 & 3.9 & 4.1 \\
\hline Value of imputed banking services & 12.0 & 11.0 & 1.5 & 8.1 & 6.7 \\
\hline Net indirect taxes & 16.1 & 2.1 & 7.7 & -0.9 & 4.2 \\
\hline GDP at market prices & 3.5 & 5.3 & 5.0 & 2.3 & 3.4 \\
\hline
\end{tabular}

Sources: The Central Bureau of Statistics in Nepal, and Nepal Rastra Bank. 
Table 3. Nepal: Gross Domestic Product by Expenditure Components, 1994/95-1998/99

\begin{tabular}{|c|c|c|c|c|c|}
\hline & $1994 / 95$ & $1995 / 96$ & $1996 / 97$ & $1997 / 98$ & $\begin{array}{r}\text { Est. } \\
1998 / 99\end{array}$ \\
\hline & \multicolumn{4}{|c|}{ (In billions of Nepalese rupees, at current prices) } & - \\
\hline GDP at market prices & 219.2 & 248.9 & 280.5 & 296.5 & 344.9 \\
\hline Consumption & 186.7 & 214.5 & 241.4 & 268.3 & 308.5 \\
\hline Public & 20.3 & 23.0 & 25.0 & 27.5 & 33.6 \\
\hline Private & 166.4 & 191.5 & 216.4 & 240.8 & 274.9 \\
\hline Gross domestic investment & 55.2 & 68.0 & 71.1 & 61.4 & 58.0 \\
\hline Gross fixed investment & 48.4 & 56.1 & 60.8 & 62.8 & 67.3 \\
\hline Public & 15.1 & 17.6 & 19.4 & 20.0 & 20.5 \\
\hline Private & 33.3 & 38.5 & 41.4 & 42.8 & 46.8 \\
\hline Change in stocks & 6.9 & 11.9 & 10.3 & -1.4 & -9.3 \\
\hline Net exports $1 /$ & -22.5 & -33.7 & -31.7 & -32.5 & -21.0 \\
\hline Exports & 55.2 & 57.1 & 75.8 & 71.0 & 82.3 \\
\hline \multirow[t]{2}{*}{ Imports } & -77.7 & -90.8 & -107.5 & -103.5 & -103.3 \\
\hline & \multicolumn{5}{|c|}{ (Percentage share in nominal GDP) } \\
\hline Consumption & 85.2 & 86.2 & 86.0 & 90.5 & 89.4 \\
\hline Public & 9.2 & 9.2 & 8.9 & 9.3 & 9.7 \\
\hline Private & 75.9 & 76.9 & 77.1 & 81.2 & 79.7 \\
\hline Gross domestic investment & 25.2 & 27.3 & 25.3 & 20.7 & 16.8 \\
\hline Gross fixed investment & 22.1 & 22.5 & 21.7 & 21.2 & 19.5 \\
\hline Public & 6.9 & 7.1 & 6.9 & 6.7 & 5.9 \\
\hline Private & 15.2 & 15.4 & 14.8 & 14.4 & 13.6 \\
\hline Change in stocks & 3.1 & 4.8 & 3.7 & -0.5 & -2.7 \\
\hline Net exports & -10.3 & -13.5 & -11.3 & -11.0 & -6.1 \\
\hline Exports & 25.2 & 22.9 & 27.0 & 23.9 & 23.9 \\
\hline Imports & -35.5 & -36.5 & -38.3 & -34.9 & -30.0 \\
\hline
\end{tabular}

Sources: The Central Bureau of Statistics in Nepal and Nepal Rastra Bank.

1/ Exports and imports of goods and services reflect the revised coverage of the balance of payments. 
Table 4. Nepal: Saving and Investment, 1994/95-1998/99

\begin{tabular}{|c|c|c|c|c|c|}
\hline & $1994 / 95$ & $1995 / 96$ & $1996 / 97$ & $1997 / 98$ & $\begin{array}{r}\text { Est. } \\
1998 / 99\end{array}$ \\
\hline & \multicolumn{5}{|c|}{ (In billions of Nepalese rupees, at current prices) } \\
\hline Gross national savings & 38.1 & 38.9 & 44.8 & 35.4 & 44.3 \\
\hline Public sector $1 /$ & 3.1 & -1.1 & 2.4 & 1.1 & 0.3 \\
\hline Private sector & 35.0 & 40.0 & 42.4 & 34.3 & 44.0 \\
\hline Gross domestic investment & 55.2 & 68.0 & 71.1 & 61.4 & 58.0 \\
\hline Gross fixed investment & 48.4 & 56.1 & 60.8 & 62.8 & 67.3 \\
\hline Public sector & 15.1 & 17.6 & 19.4 & 20.0 & 20.5 \\
\hline Private sector & 33.3 & 38.5 & 41.4 & 42.8 & 46.8 \\
\hline Change in stocks & 6.9 & 11.9 & 10.3 & -1.4 & -9.3 \\
\hline Saving-investment gap & -17.1 & -29.1 & -26.3 & -26.0 & -13.6 \\
\hline Public sector & -12.0 & -18.7 & -17.0 & -18.9 & -20.2 \\
\hline \multirow[t]{2}{*}{ Private sector } & -5.2 & -10.4 & -9.3 & -7.1 & 6.6 \\
\hline & \multicolumn{5}{|c|}{ (In percent of nominal GDP) } \\
\hline Gross national savings & 17.4 & 15.6 & 16.0 & 11.9 & 12.9 \\
\hline Public sector $1 /$ & 1.4 & -0.4 & 0.8 & 0.4 & 0.1 \\
\hline Private sector & 16.0 & 16.0 & 15.2 & 11.5 & 12.8 \\
\hline Gross domestic investment & 25.2 & 27.3 & 25.3 & 20.7 & 16.8 \\
\hline Gross fixed investment & 22.1 & 22.5 & 21.7 & 21.2 & 19.5 \\
\hline Public sector & 6.9 & 7.1 & 6.9 & 6.7 & 5.9 \\
\hline Private sector & 15.2 & 15.4 & 14.8 & 14.4 & 13.6 \\
\hline Change in stocks & 3.1 & 4.8 & 3.7 & -0.5 & -2.7 \\
\hline Saving-investment gap & -7.8 & -11.7 & -9.3 & -8.8 & -3.9 \\
\hline Public sector & -5.5 & -7.5 & -6.1 & -6.3 & -5.8 \\
\hline Private sector & -2.3 & -4.2 & -3.2 & -2.5 & 1.9 \\
\hline
\end{tabular}

Sources: The Central Bureau of Statistics in Nepal and Nepal Rastra Bank.

1/ Defined as revenue less regular expenditure and estimated recurrent costs of development expenditure. 
Table 5. Nepal: Agricultural Production and Yields, 1994/95-1998/99

\begin{tabular}{|c|c|c|c|c|c|c|c|c|c|}
\hline & $1994 / 95$ & $1995 / 96$ & $1996 / 97$ & $1997 / 98$ & $1998 / 99$ & $1995 / 96$ & $1996 / 97$ & $1997 / 98$ & $1998 / 99$ \\
\hline & \multicolumn{5}{|c|}{ (In thousands of metric tons) } & \multicolumn{4}{|c|}{ (Percentage change) } \\
\hline Production by major crops & & & & & & & & & \\
\hline Foodgrains & 5,412 & 6,247 & 6,395 & 6,331 & 6,465 & 15.4 & 2.4 & -1.0 & 2.1 \\
\hline Paddy & 2,928 & 3,579 & 3,699 & 3,641 & 3,710 & 22.2 & 3.4 & -1.6 & 1.9 \\
\hline Wheat & 914 & 1,013 & 1,056 & 1,001 & 1,087 & 10.9 & 4.2 & --5.2 & -8.6 \\
\hline Maize & 1,273 & 1,331 & 1,312 & 1,367 & 1,346 & 4.5 & -1.4 & 4.2 & -1.6 \\
\hline Millet & 268 & 282 & 289 & 285 & 291 & 5.6 & 2.3 & -1.3 & 2.2 \\
\hline Barley & 30 & 41 & 39 & 37 & 32 & 40.0 & 6.3 & -4.4 & -14.1 \\
\hline Cash crops & 2,461 & 2,604 & 2,721 & 2,782 & 3,202 & 5.8 & 4.5 & 2.2 & 15.1 \\
\hline Sugarcane & 1,501 & 1,569 & 1,622 & 1,718 & 1,972 & 4.5 & 3.4 & 5.9 & 14.8 \\
\hline Jute & 11 & 15 & 14 & 15 & 16 & 31.6 & -6.7 & 10.0 & 1.9 \\
\hline Oilseeds & 102 & 116 & 119 & 109 & 120 & 13.6 & 2.7 & -8.2 & 9.5 \\
\hline Potato & 840 & 898 & 962 & 935 & 1,091 & 6.9 & 7.0 & -2.8 & 16.7 \\
\hline Tobacco & 7 & 6 & 5 & 5 & 4 & -17.9 & -7.3 & -9.8 & -15.2 \\
\hline Distribution of fertilizer I/ & 176 & 133 & 122 & 109 & 182 & -24.4 & -8.3 & -10.7 & 67.0 \\
\hline & \multicolumn{5}{|c|}{ (In thousands of hectares) } & \multicolumn{4}{|c|}{ (Percentage change) } \\
\hline Area under culltivation $2 /$ & & & & & & & & & \\
\hline Foodgrains & 3,107 & 3,242 & 3,267 & 3,243 & 3,253 & 4.3 & 0.8 & -0.7 & 0.3 \\
\hline Paddy & 1,421 & 1,497 & 1,511 & 1,506 & 1,514 & 5.3 & 0.9 & -0.3 & 0.5 \\
\hline Wheat & 634 & 654 & 667 & 640 & 641 & 3.2 & 2.0 & -4.0 & 0.2 \\
\hline Maize & 771 & 792 & 794 & 799 & 802 & 2.7 & 0.3 & 0.6 & 0.4 \\
\hline Millet & 250 & 260 & 260 & 262 & 264 & 4.0 & 0.0 & 0.8 & 0.8 \\
\hline Barley & $\cdot 31$ & 39 & 35 & 36 & 32 & 25.8 & -10.3 & 2.9 & -11.1 \\
\hline Cash crops & 325 & 353 & 356 & 361 & 379 & 8.6 & 0.8 & 1.4 & 5.0 \\
\hline Sugarcane & 42 & 45 & 46 & 49 & 54 & 7.1 & 2.2 & 6.5 & 10.2 \\
\hline Jute & 9 & 11 & 11 & 12 & 12 & 22.2 & 0.0 & 9.1 & 0.0 \\
\hline Oilseeds & 170 & 185 & 182 & 179 & 190 & 8.8 & -1.6 & -1.6 & 6.1 \\
\hline Potato & 97 & 106 & 111 & 116 & 118 & 9.3 & 4.7 & 4.5 & 1.7 \\
\hline \multirow[t]{2}{*}{ Tobseco } & 7 & 6 & 6 & 5 & 5 & -14.3 & 0.0 & -16.7 & 0.0 \\
\hline & \multicolumn{5}{|c|}{ (In metric tons/hectares) } & \multicolumn{4}{|c|}{ (Percentage change) } \\
\hline Yields & & & & & & & & & \\
\hline Foodgrains & 1.7 & 1.9 & 2.0 & 2.0 & 2.0 & 10.6 & 1.6 & -0.3 & 1.8 \\
\hline Paddy & 2.1 & 2.4 & 2.4 & 2.4 & 2.5 & 16.0 & 2.4 & -12 & 1.4 \\
\hline Wheat & 1.4 & 1.5 & 1.6 & 1.6 & 1.7 & 7.5 & 2.2 & -12 & 8.4 \\
\hline Maize & 1.7 & 1.7 & 1.7 & 1.7 & 1.7 & 1.8 & -1.7 & 3.5 & -1.9 \\
\hline Millet & 1.1 & 1.1 & 1.1 & 1.1 & 1.1 & 1.5 & 2.3 & -2.1 & 1.4 \\
\hline Barley & 1.0 & 1.1 & 1.1 & 1.0 & 1.0 & 11.3 & 4.4 & -7.0 & -3.3 \\
\hline Cash crops & 7.6 & 7.4 & 7.6 & 7.7 & 8.4 & -2.6 & 3.6 & 0.8 & 9.6 \\
\hline Sugarcane & 35.7 & 34.9 & 35.3 & 35.1 & 36.5 & -2.4 & 1.1 & -0.6 & 4.2 \\
\hline Jute & 1.3 & 1.4 & 1.3 & 1.3 & 1.3 & 7.7 & -6.7 & 0.8 & 1.9 \\
\hline Oilseed & 0.6 & 0.6 & 0.7 & 0.6 & 0.6 & 4.4 & 4.4 & -6.7 & 3.2 \\
\hline Potato & 8.7 & 8.5 & 8.7 & 8.1 & 9.2 & -2.1 & 2.2 & -7.0 & 14.7 \\
\hline Tobacco & 1.0 & 0.9 & 0.9 & 0.9 & 0.8 & -4.2 & -7.3 & 8.2 & -15.2 \\
\hline
\end{tabular}

Source: The Central Bureau of Statistics in Nepal.

1/ Private sector has participated in fertilizer trading activity since November 1997.

2/ Areas cultivated with more than one crop are included under each crop. 
Table 6. Nepal: Manufacturing Production Indices, 1995/96-1998/99

Weights $1 /$ 1995/96 1996/97 1997/98 1998/99

$1995 / 96 \quad 1996 / 97 \quad 1997 / 98 \quad 1998 / 99$

\begin{tabular}{|c|c|c|c|c|c|c|c|c|c|}
\hline \multirow[b]{2}{*}{ Overall production } & \multicolumn{5}{|c|}{ (Indices $1991 / 92=100$ ) } & \multicolumn{4}{|c|}{ (Percentage change) } \\
\hline & 100.0 & 144 & 155 & 158 & 169 & 9.0 & 7.1 & 2.4 & 6.5 \\
\hline Food & 16.1 & 219 & 238 & 276 & 295 & 6.0 & 8.8 & 15.7 & 7.0 \\
\hline Of which: Sugar & 1.9 & 262 & 302 & 320 & 338 & 29.1 & 15.0 & 6.1 & 5.6 \\
\hline Vegetable ghee & 1.7 & 127 & 112 & 129 & 149 & -5.3 & -12.0 & 15.6 & 15.4 \\
\hline Rice & 3.4 & 396 & 413 & 514 & 543 & 4.2 & 4.4 & 24.5 & 5.6 \\
\hline Soybeen oil & 2.3 & 135 & 214 & 246 & 281 & 17.7 & 58.0 & 15.1 & 14.1 \\
\hline Processed milk & 2.4 & 163 & 169 & 183 & 189 & 1.4 & 3.3 & 8.4 & 3.1 \\
\hline Beverage & 3.9 & 172 & 193 & 213 & 236 & 19.6 & 12.2 & 10.3 & 10.9 \\
\hline Tobacco & 4.8 & 116 & 119 & 95 & 108 & 7.8 & 2.8 & -20.4 & 14.2 \\
\hline Textile & 35.8 & 109 & 108 & 101 & 116 & 6.8 & -1.0 & -6.3 & 15.1 \\
\hline Of which: Synthetic cloth & 3.2 & 242 & 291 & 308 & 272 & 24.0 & 20.0 & 5.7 & -11.7 \\
\hline Woolen carpet & 25.1 & 82 & 84 & 75 & 94 & 0.3 & 2.1 & -10.0 & 24.3 \\
\hline Woolen thread & 4.7 & 128 & 94 & 70 & $\ldots$ & 0.9 & -26.7 & -25.4 & $\ldots$ \\
\hline Readymade garments & 10.5 & 159 & 154 & 148 & 159 & 10.3 & -3.3 & -3.9 & 7.7 \\
\hline Processed leather & 0.9 & 66 & 47 & 51 & 52 & -42.0 & -29.0 & 8.8 & 2.0 \\
\hline Footwear manufacturing & 0.3 & 67 & 36 & 40 & $\ldots$ & -12.3 & -46.7 & 13.1 & $\ldots$ \\
\hline Wood products & 2.0 & 120 & 182 & 180 & 188 & 10.5 & 51.1 & -1.0 & 4.4 \\
\hline Paper & 0.8 & 338 & 359 & 362 & 369 & 2.9 & 6.3 & 0.8 & 1.7 \\
\hline Other chemical products & 3.9 & 141 & 215 & 203 & 225 & 10.9 & 52.2 & -5.4 & 10.7 \\
\hline Rubber products & 0.3 & 138 & 132 & 131 & $\ldots$ & 36.8 & -4.9 & -0.6 & $\ldots$ \\
\hline Plastic products & 1.3 & 119 & 130 & 118 & 140 & 3.5 & 9.5 & -9.3 & 18.4 \\
\hline Nonmetallic mineral products & 13.3 & 140 & 151 & 166 & 170 & 11.5 & 7.8 & 9.8 & 2.4 \\
\hline Of which: Bricks & 7.7 & 127 & 146 & 121 & 134 & 23.0 & 14.9 & -16.9 & 10.1 \\
\hline Cement & 5.6 & 158 & 158 & 227 & 220 & 1.0 & 0.0 & 43.8 & -3.3 \\
\hline Iron and steel basic industries & 2.2 & 131 & 149 & 136 & 158 & 8.9 & 14.3 & -9.1 & 16.3 \\
\hline Cutlery and handtools & 2.6 & 172 & 218 & 219 & 239 & 38.3 & 26.8 & 0.2 & 9.2 \\
\hline Electrical industrial machinery & & & & & & & & & \\
\hline apparatus, appliances, etc. & 1.1 & 153 & 138 & 149 & 152 & 47.6 & -9.4 & 7.5 & 2.2 \\
\hline
\end{tabular}

Source: The Central Bureau of Statistics in Nepal.

1/ Weights are based on the Census of Manufacturing Establishments (1991/92). 
Table 7. Nepal: Energy Consumption, 1994/95-1998/99

\begin{tabular}{|c|c|c|c|c|c|}
\hline & $1994 / 95$ & $1995 / 96$ & $1996 / 97$ & $1997 / 98$ & 1998/99 \\
\hline & \multicolumn{4}{|c|}{ (In thousands of tons of coal equivalent) } & - \\
\hline Traditional & 8,804 & 8,995 & 9,191 & 9,392 & 9,596 \\
\hline Of which: Fuelwood & 7,864 & 8,035 & 8,210 & 8,389 & 8,572 \\
\hline Commercial & 799 & 986 & 1,151 & 1,298 & 1,399 \\
\hline Petroleum & 606 & 777 & 806 & 924 & 995 \\
\hline Coal & 97 & 105 & 233 & 253 & 275 \\
\hline Hydropower & 97 & 104 & 112 & 121 & 129 \\
\hline \multirow[t]{2}{*}{ Total } & 9,603 & 9,982 & 10,342 & 10,689 & 10,995 \\
\hline & \multicolumn{5}{|c|}{ (Percentage change) } \\
\hline Traditional & 2.2 & 2.2 & 2.2 & 2.2 & 2.2 \\
\hline Of which : Fuelwood & 2.2 & 2.2 & 2.2 & 2.2 & 2.2 \\
\hline Commercial & 7.7 & 23.4 & 16.7 & 12.8 & 7.8 \\
\hline Petroleum & 6.8 & 28.3 & 3.8 & 14.6 & 7.7 \\
\hline Coal & 8.9 & 8.6 & 121.0 & 8.7 & 8.7 \\
\hline Hydropower & 12.4 & 8.0 & 7.1 & 8.1 & 7.0 \\
\hline Total & 2.6 & 3.9 & 3.6 & 3.4 & 2.9 \\
\hline
\end{tabular}

Source: Data provided by the Nepalese authorities. 
Table 8. Nepal: Tourism Indicators, 1994-99

\begin{tabular}{|c|c|c|c|c|c|c|c|}
\hline & \multirow[b]{2}{*}{1994} & \multirow[b]{2}{*}{1995} & \multirow[b]{2}{*}{1996} & \multirow[b]{2}{*}{1997} & \multirow[b]{2}{*}{1998} & \multicolumn{2}{|c|}{ January-October } \\
\hline & & & & & & 1998 & 1999 \\
\hline Tourist arrivals (in thousands) & 326.5 & 363.4 & 393.6 & 421.8 & 463.6 & 319.0 & 345.6 \\
\hline (Percentage change) & 11.2 & 11.3 & 8.3 & 7.2 & 9.9 & $\ldots$ & 8.3 \\
\hline Of which: Europe & 135.2 & 137.7 & 138.8 & 143.4 & 157.8 & $\ldots$ & $\ldots$ \\
\hline India $\mathbf{1}$ & 102.5 & 117.3 & 122.5 & 133.4 & 143.2 & $\cdots$ & $\ldots$ \\
\hline Japan & 19.6 & 25.4 & 28.9 & 35.0 & 37.3 & $\ldots$ & ... \\
\hline \multicolumn{8}{|l|}{ United States } \\
\hline and Canada & 26.1 & 29.7 & 30.6 & 36.3 & 43.0 & $\cdots$ & ... \\
\hline Average days of stay & 10.0 & 11.3 & 13.5 & 10.5 & 10.8 & $\ldots$ & $\ldots$ \\
\hline \multicolumn{8}{|l|}{ Per capita erpenditure } \\
\hline (In Nrs) $2 /$ & 14,400 & 24,617 & 24,344 & 23,226 & 31,282 & $\cdots$ & ... \\
\hline (In U.S. dollars) $2 /$ & 394 & 474 & 430 & 402 & 476 & $\ldots$ & $\ldots$ \\
\hline (Percentage change) & 16.9 & 20.5 & -9.3 & -6.6 & 18.4 & $\cdots$ & $\ldots$ \\
\hline Hotel-bed capacity & 17,730 & 21,807 & 25,638 & 27,612 & 28,878 & $\ldots$ & $\ldots$ \\
\hline (Percentage change) & 41.3 & 23.0 & 17.6 & 7.7 & 4.6 & $\ldots$ & $\ldots$ \\
\hline
\end{tabular}

Source: Data provided by the Nepalese authorities.

1/ By air only.

2/ Excluding Indian tourists. 
Table 9. Nepal: Changes in the Consumer Price Index, 1994/95-1998/99

(Annual percentage change)

\begin{tabular}{|c|c|c|c|c|c|}
\hline & $1994 / 95$ & $1995 / 96$ & $1996 / 97$ & $1997 / 98$ & 1998/99 \\
\hline & & & & & - \\
\hline Overall national index & 7.6 & 8.1 & 7.8 & 4.0 & 12.7 \\
\hline \multicolumn{6}{|l|}{ By commodity } \\
\hline Food and beverages & 7.3 & 8.9 & 7.8 & 3.3 & 17.3 \\
\hline Foodgrains & 7.9 & 8.5 & 10.3 & -0.4 & 19.7 \\
\hline Milk and milk products & 1.3 & 10.8 & 10.7 & 6.0 & 8.5 \\
\hline Oil and fats & 11.1 & 13.2 & -0.2 & 6.8 & 30.2 \\
\hline Beverages & 3.9 & 6.9 & 0.4 & 16.2 & 6.7 \\
\hline Vegetables and fruits & 5.0 & 3.7 & 0.0 & 9.0 & 22.8 \\
\hline Other goods and services & 8.1 & 6.7 & 7.7 & 5.2 & 4.3 \\
\hline Cloth, clothing, and sewing services & 10.1 & 7.2 & 5.8 & 4.7 & 4.2 \\
\hline Fuel, light, and water & 3.2 & 3.8 & 10.2 & 2.6 & 1.6 \\
\hline \multicolumn{6}{|l|}{ Regional indices } \\
\hline Terai & 7.4 & 9.5 & 8.5 & 3.5 & 15.2 \\
\hline Hills & 7.8 & 9.5 & 8.6 & 3.8 & 12.5 \\
\hline Kathmandu & 8.0 & 6.0 & 6.6 & 4.7 & 9.6 \\
\hline Domestic goods & 8.7 & 5.9 & 6.6 & 4.3 & 10.3 \\
\hline Imported goods & 4.3 & 5.8 & 6.7 & 7.1 & 5.9 \\
\hline
\end{tabular}

Source: The Central Bureau of Statistics in Nepal. 
Table 10. Nepal: Monthly Wages in Major Sectors, 1994/95-1998/99

\begin{tabular}{|c|c|c|c|c|c|}
\hline & $1994 / 95$ & $1995 / 96$ & $1996 / 97$ & $1997 / 98$ & $1998 / 99$ \\
\hline & \multicolumn{5}{|c|}{ (In Nepalese rupees) } \\
\hline \multicolumn{6}{|l|}{ Agriculture } \\
\hline Kathmandu & 2,550 & 2,800 & 3,000 & 3,000 & 3,000 \\
\hline Birgunj & 1,350 & 1,500 & 1,500 & 1,500 & 1,500 \\
\hline Biratnagar & 1,350 & 1,350 & 1,350 & 1,350 & 1,487 \\
\hline \multicolumn{6}{|l|}{ Industry $\mathbf{y}$} \\
\hline Skilled & 1,610 & 1,610 & 1,610 & 1,960 & 1,960 \\
\hline Unskilled & 1,450 & 1,450 & 1,450 & 1,800 & 1,800 \\
\hline \multicolumn{6}{|l|}{ Conatruction $2 J$} \\
\hline \multicolumn{6}{|l|}{ Skilled } \\
\hline Kathmandu & 5,100 & 5,350 & $5,550^{\circ}$ & 5,700 & 5,700 \\
\hline Birgunj & 2,820 & 3,300 & 3,300 & 3,375 & 3,913 \\
\hline Biratnagar & 3,600 & 3,600 & 3,600 & 3,850 & 4,475 \\
\hline \multicolumn{6}{|l|}{ Semi-skilled } \\
\hline Kathmandu & 4,500 & 4,625 & 4,675 & 4,950 & 4,950 \\
\hline Biratnagar & 3,000 & 3,000 & 3,000 & 3,250 & 3,875 \\
\hline \multicolumn{6}{|l|}{ Unskilled } \\
\hline Kathmandu & 2,700 & 2,950 & 3,000 & 3,000 & 3,000 \\
\hline \multirow[t]{2}{*}{ Biratnagar } & 1,800 & 1,800 & 1,800 & 1,925 & 2,375 \\
\hline & \multicolumn{5}{|c|}{ (In U.S. dollars) } \\
\hline \multicolumn{6}{|l|}{ Agriculture } \\
\hline Kathmandu & 51.2 & 50.7 & 52.6 & 48.5 & 43.8 \\
\hline Birgunj & 27.1 & 27.2 & 26.3 & 24.3 & 21.9 \\
\hline Biratnagar & 27.1 & 24.4 & 23.7 & 21.8 & 21.7 \\
\hline \multicolumn{6}{|l|}{ Industry $1 /$} \\
\hline Skilled & 32.3 & 29.2 & 28.2 & 31.7 & 28.6 \\
\hline Unskilled & 29.1 & 26.3 & 25.4 & 29.1 & 26.3 \\
\hline \multicolumn{6}{|l|}{ Construction $2 /$} \\
\hline \multicolumn{6}{|l|}{ Skilled } \\
\hline Kathmandu & 102.4 & 96.9 & 97.3 & 92.2 & 83.2 \\
\hline Birgunj & 56.6 & 59.8 & 57.9 & 54.6 & 57.1 \\
\hline Biratnagar & 72.3 & 65.2 & 63.1 & 62.3 & 65.3 \\
\hline \multicolumn{6}{|l|}{ Semi-skilled } \\
\hline Kathmandu & 90.4 & 83.8 & 82.0 & 80.1 & 72.2 \\
\hline Biratnagar & 60.2 & 54.3 & 52.6 & 52.6 & 56.5 \\
\hline \multicolumn{6}{|l|}{ Unskilled } \\
\hline Kathmandu & 54.2 & 53.4 & 52.6 & 48.5 & 43.8 \\
\hline Biratnagar & 36.1 & 32.6 & 31.6 & 31.1 & 34.7 \\
\hline
\end{tabular}

Source: Data provided by the Nepalese authorities.

1/ Minimum monthly wage, including allowances, which are the same in Kathmandu, Birgunj and Biratnagar. 2/ Carpenters and masons. 
Table 11. Nepal: Social Indicators

\begin{tabular}{|c|c|c|c|c|c|c|}
\hline & & tost singles & & Same re & ion/incoms & roup \\
\hline & $1970-75$ & $1980-85$ & $1992-97$ & India & $\begin{array}{l}\text { South } \\
\text { Asia }\end{array}$ & $\begin{array}{l}\text { Low } \\
\text { income }\end{array}$ \\
\hline $\begin{array}{l}\text { Total population, mid-year (millions) } \\
\text { Growth rate (percent annual average) } \\
\text { Urban population (percent of population) } \\
\text { Total fertility fnte (births per woman) } \\
\text { Total labor force (millions) } \\
\text { Females in labor force (percent) } \\
\text { Labor force participation rate }\end{array}$ & $\begin{array}{r}12.8 \\
2.4 \\
5.0 \\
6.3 \\
\ldots \\
\ldots \\
\ldots\end{array}$ & $\begin{array}{r}16.5 \\
2.6 \\
7.8 \\
6.1 \\
8 \\
39 \\
48\end{array}$ & $\begin{array}{r}22.3 \\
2.0 \\
10.9 \\
4.4 \\
12 \\
40 \\
48\end{array}$ & $\begin{array}{r}945.0 \\
1.7 \\
27.0 \\
2.6 \\
400 \\
32 \\
43\end{array}$ & $\begin{array}{r}1,281.3 \\
1.5 \\
27.0 \\
3.5 \\
546 \\
33 \\
43\end{array}$ & $\begin{array}{r}2,035.6 \\
1.7 \\
28.4 \\
4.0 \\
\ldots . \\
-\begin{aligned} 41 \\
50\end{aligned}\end{array}$ \\
\hline $\begin{array}{l}\text { Poverty } \\
\text { National headcount index } \\
\text { Urban heodcount index } \\
\text { Rural headcount index }\end{array}$ & $\begin{array}{l}\cdots \\
\cdots \\
\cdots\end{array}$ & $\begin{array}{l}\cdots \\
\cdots \\
\cdots\end{array}$ & $\begin{array}{l}42 \\
23 \\
44\end{array}$ & $\begin{array}{l}35 \\
31 \\
37\end{array}$ & $\begin{array}{l}\cdots \\
\cdots \\
\cdots\end{array}$ & $\begin{array}{l}\cdots \\
\cdots \\
\cdots\end{array}$ \\
\hline $\begin{array}{l}\text { Income } \\
\text { GNP per capita (U.S. dollars) } \\
\text { Consumer price index }(1995=100) \\
\text { Food price index }(1995=100)\end{array}$ & $\begin{array}{r}120 \\
17 \\
\ldots\end{array}$ & $\begin{array}{r}170 \\
35 \\
33\end{array}$ & $\begin{array}{l}220 \\
114 \\
111\end{array}$ & $\begin{array}{r}340 \\
117 \\
\ldots\end{array}$ & $\begin{array}{r}380 \\
117 \\
\ldots\end{array}$ & $\begin{array}{r}350 \\
122 \\
\ldots\end{array}$ \\
\hline $\begin{array}{l}\text { Income/consumption distribution } \\
\text { Gini index } \\
\text { Lowest quintile (percent of income or consumption) } \\
\text { Highest quintile (percent of income or consumption) }\end{array}$ & $\begin{array}{l}\cdots \\
\cdots \\
\cdots\end{array}$ & $\begin{array}{l}\cdots \\
\cdots \\
\cdots\end{array}$ & $\begin{array}{r}36.7 \\
7.6 \\
44.8\end{array}$ & $\begin{array}{r}29.7 \\
9 \\
39\end{array}$ & $\begin{array}{l}\cdots \\
\cdots \\
\cdots\end{array}$ & $\begin{array}{l}\cdots \\
\cdots \\
\cdots\end{array}$ \\
\hline $\begin{array}{l}\text { Public expenditure } \\
\text { Health (percent of GDP) } \\
\text { Education (percent of GNP) } \\
\text { Social security and wolfare (percent of GDP) }\end{array}$ & $\begin{array}{l}1.5 \\
0.1\end{array}$ & $\begin{array}{l}2.6 \\
0.1\end{array}$ & $\begin{array}{r}1.2 \\
2.8 \\
\ldots .\end{array}$ & $\begin{array}{c}0.7 \\
3.5 \\
\ldots\end{array}$ & $\begin{array}{r}0.8 \\
3.0 \\
\ldots\end{array}$ & $\begin{array}{r}1.0 \\
5.5 \\
\ldots . .\end{array}$ \\
\hline $\begin{array}{l}\text { Net primary school enrollment rate (percent of age grou } \\
\text { Total } \\
\text { Male } \\
\text { Female } \\
\text { Gross secondary school enrollment } \\
\text { Total } \\
\text { Male } \\
\text { Female }\end{array}$ & $\begin{array}{r}12 \\
19 \\
4\end{array}$ & $\begin{array}{l}27 \\
39 \\
14\end{array}$ & $\begin{array}{l}\ldots \\
\cdots \\
\cdots \\
32 \\
45 \\
18\end{array}$ & $\begin{array}{c}\ldots \\
\ldots \\
\ldots \\
49 \\
59 \\
39\end{array}$ & $\begin{array}{l}99 \\
\ldots \\
\ldots\end{array}$ & $\begin{array}{c}95 \\
\ldots \\
\ldots\end{array}$ \\
\hline $\begin{array}{l}\text { Adult literacy (percent) } \\
\text { Fomalo literacy }\end{array}$ & $\begin{array}{l}\cdots \\
\cdots\end{array}$ & 22 & $\begin{array}{l}27 \\
20\end{array}$ & $\begin{array}{l}51 \\
38\end{array}$ & $\begin{array}{l}51 \\
36\end{array}$ & $\begin{array}{l}54 \\
35\end{array}$ \\
\hline $\begin{array}{l}\text { Access to safo water (percent of population) } \\
\text { Total } \\
\text { Urban } \\
\text { Rural }\end{array}$ & $\begin{array}{r}8 \\
85 \\
5\end{array}$ & $\begin{array}{l}24 \\
78 \\
20\end{array}$ & $\begin{array}{l}59 \\
61 \\
59\end{array}$ & $\begin{array}{l}81 \\
85 \\
79\end{array}$ & $\begin{array}{l}81 \\
84 \\
80\end{array}$ & $\begin{array}{l}69 \\
80 \\
66\end{array}$ \\
\hline Access to electricity (percent) & $\ldots$ & $\ldots$ & 15 & 54 & $\cdots$ & $\ldots$ \\
\hline $\begin{array}{l}\text { Population per physician } \\
\text { Population per hospital bed }\end{array}$ & $\cdots$ & $\begin{array}{r}30,221 \\
5,719\end{array}$ & $\begin{array}{r}13,617 \\
4,308\end{array}$ & $\begin{array}{l}2,459 \\
1,503\end{array}$ & $\begin{array}{l}2,500 \\
1,429\end{array}$ & 1,152 \\
\hline $\begin{array}{l}\text { Immunization rate (percent under } 12 \text { months) } \\
\text { Meesles } \\
\text { DPT } \\
\text { Child malnutrition (percent under } 5 \text { years) }\end{array}$ & 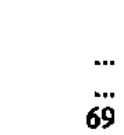 & $\begin{array}{l}34 \\
32 \\
\ldots\end{array}$ & $\begin{array}{l}85 \\
78 \\
47\end{array}$ & $\begin{array}{l}89 \\
92 \\
39\end{array}$ & $\begin{array}{l}81 \\
87 \\
53\end{array}$ & $\begin{array}{c}74 \\
76 \\
\ldots\end{array}$ \\
\hline $\begin{array}{l}\text { Life expectancy at birth (in yoars) } \\
\text { Total } \\
\text { Malc } \\
\text { Female }\end{array}$ & $\begin{array}{l}43 \\
44 \\
43\end{array}$ & $\begin{array}{l}49 \\
50 \\
48\end{array}$ & $\begin{array}{l}57 \\
58 \\
57\end{array}$ & $\begin{array}{l}63 \\
62 \\
63\end{array}$ & $\begin{array}{l}62 \\
62 \\
63\end{array}$ & $\begin{array}{l}59 \\
58 \\
60\end{array}$ \\
\hline $\begin{array}{l}\text { Mortality } \\
\text { Infant (per thousand live birtis) } \\
\text { Under } 5 \text { (per thousand live births) } \\
\text { Adult (15-59) }\end{array}$ & $\begin{array}{l}160 \\
234\end{array}$ & $\begin{array}{l}125 \\
180\end{array}$ & $\begin{array}{r}83 \\
117\end{array}$ & $\begin{array}{l}65 \\
85\end{array}$ & $\begin{array}{r}77 \\
100\end{array}$ & $\begin{array}{r}82 \\
118\end{array}$ \\
\hline $\begin{array}{c}\text { Male (per } 1,000 \text { population) } \\
\text { Female (per } 1,000 \text { population) } \\
\text { Maternal (per } 100,000 \text { live births) }\end{array}$ & $\begin{array}{r}482 \\
476 \\
\ldots\end{array}$ & $\begin{array}{r}376 \\
395 \\
\ldots\end{array}$ & $\begin{array}{r}274 \\
314 \\
1,500\end{array}$ & $\begin{array}{r}21.2 \\
202 \\
437\end{array}$ & $\begin{array}{r}219 \\
212 \\
\ldots\end{array}$ & $\begin{array}{r}274 \\
255 \\
\ldots\end{array}$ \\
\hline
\end{tabular}

Sources: Staff reports, EDSS, World Bank 1999 Wordd Development Indicators CD-ROM. 
Table 12. Nepal: Balance of Payments by Area, 1995/96-1998/99

(In millions of U.S. dollars)

\begin{tabular}{|c|c|c|c|c|c|c|c|c|c|c|c|c|}
\hline & \multicolumn{3}{|c|}{$1995 / 96$} & \multicolumn{3}{|c|}{ 1996/97 } & \multicolumn{3}{|c|}{$1997 / 98$} & \multicolumn{3}{|c|}{ 1998/99 } \\
\hline & \multicolumn{3}{|c|}{ Countries } & India & Countries & Total & India & Countries & Total & India & Countries & Total \\
\hline Trade balance & -136 & -613 & -748 & 308 & -898 & -589 & -35 & -693 & -727 & -191 & -462 & -653 \\
\hline Exports, f.o.b. & 308 & 293 & 602 & 855 & 305 & 1,160 & 553 & 302 & 855 & 410 & 342 & 752 \\
\hline Merchandise exports & 67 & 293 & 360 & 92 & 305 & 397 & 142 & 302 & 444 & 193 & 342 & 535 \\
\hline Re-exports & 242 & 0 & 242 & 763 & 0 & 763 & 411 & $\mathbf{0}$ & 411 & 217 & 0 & 217 \\
\hline Imports, c.i.f. & 444 & 906 & 1,350 & 547 & 1,203 & 1,750 & 588 & 995 & 1,582 & 601 & 804 & 1,405 \\
\hline Services (net) & 68 & 99 & 167 & 33 & 107 & 139 & 18 & 186 & 204 & 38 & 276 & 314 \\
\hline Receipts & 163 & 298 & 461 & 118 & 263 & 381 & 108 & 327 & 435 & 140 & 406 & 546 \\
\hline Payments & 95 & 199 & 294 & 85 & 156 & 241 & 90 & 142 & 232 & 102 & 130 & 232 \\
\hline Private transfers (net) & 59 & 133 & 192 & 69 & 240 & 309 & 89 & 266 & 355 & 108 & 362 & 470 \\
\hline Receipts & 67 & 135 & 202 & 78 & 252 & 330 & 113 & 270 & 384 & 122 & 364 & 486 \\
\hline Recorded private transfers & 36 & 42 & 78 & 32 & 85 & 117 & 49 & 89 & 138 & 66 & 106 & 172 \\
\hline Estimated remittances & 31 & 94 & 125 & 46 & 168 & 213 & 64 & 182 & 245 & 56 & 259 & 315 \\
\hline Payments & 8 & 2 & 10 & 9 & 12 & 21 & 25 & 4 & 29 & 14 & 2 & 17 \\
\hline Current account balance (excluding grants) & -9 & -382 & -390 & 410 & -551 & -142 & 72 & -241 & -168 & -45 & 176 & 131 \\
\hline Official grants & 16 & 121 & 137 & 20 & 73 & 93 & 22 & 96 & 119 & 19 & 88 & 107 \\
\hline Current account balance (including grants) & 7 & -260 & -253 & 429 & -478 & -49 & 94 & -144 & -50 & -26 & 264 & 238 \\
\hline Official capital grants and toans (net) & 0 & 134 & 134 & 0 & 296 & 296 & 1 & 429 & 430 & 2 & 274 & 277 \\
\hline Official capital grants & 0 & 0 & 0 & 0 & 147 & 147 & 1 & 254 & 255 & 2 & 134 & 137 \\
\hline Oficial capital (net) & $\mathbf{0}$ & 134 & 134 & $\mathbf{0}$ & 149 & 149 & 0 & 175 & 175 & o & 140 & 140 \\
\hline Loans & 0 & 186 & 186 & 0 & 197 & 197 & 0 & 230 & 230 & $\mathbf{0}$ & 195 & 195 \\
\hline Arnortization & 0 & 52 & 52 & 0 & 48 & 48 & 0 & 55 & 55 & $\mathbf{0}$ & 55 & 55 \\
\hline Private capital and errors and omissions & -15 & 94 & 79 & -368 & 179 & -188 & -55 & -148 & -203 & 95 & -465 & -370 \\
\hline Overall balance & -8 & -36 & -40 & 62 & 8 & 59 & 40 & 137 & 177 & $\mathbf{7 2}$ & 73 & 144 \\
\hline Memorandum item: & & & & & & & & & & & & \\
\hline Current account balance (percent of GDP) & -0.2 & -8.4 & -8.6 & 8.3 & -11.2 & -2.9 & 1.5 & -5.0 & -3.5 & -0.9 & 3.5 & 2.6 \\
\hline
\end{tabular}

Sources: Data provided by the Nepalese authorities; and Fund staff estimates. 
Table 13. Nepal: Composition of Foreign Trade, 1995/96-1998/99

(In millions of U.S. dollars)

\begin{tabular}{|c|c|c|c|c|c|c|c|c|c|c|c|c|}
\hline \multirow[b]{3}{*}{ Exports, f.o.b. } & \multicolumn{3}{|c|}{$1995 / 96$} & \multicolumn{3}{|c|}{$1996 / 97$} & \multicolumn{3}{|c|}{$1997 / 98$} & \multicolumn{3}{|c|}{$1998 / 99$} \\
\hline & \multirow{2}{*}{$\begin{array}{c}\text { India } \\
\mathbf{3 0 8}\end{array}$} & $\begin{array}{l}\text { Thind } \\
\text { Coumtries }\end{array}$ & \multirow{2}{*}{$\begin{array}{c}\text { Total } \\
602\end{array}$} & \multirow{2}{*}{ India } & \multicolumn{2}{|l|}{$\begin{array}{l}\text { Third } \\
\text { Countries }\end{array}$} & India & $\begin{array}{l}\text { Third } \\
\text { ountries }\end{array}$ & Total & \multicolumn{2}{|c|}{$\begin{array}{c}\text { India } \begin{array}{c}\text { Third } \\
\text { Countries }\end{array}\end{array}$} & \multirow[t]{2}{*}{ Total } \\
\hline & & 293 & & & 305 & 1,160 & $\mathbf{5 5 3}$ & 302 & 855 & 410 & 342 & \\
\hline Merchandise exports & 67 & 293 & 360 & 92 & 305 & 397 & 142 & 302 & 445 & 193 & 342 & 535 \\
\hline Food and live animals & 23 & 12 & 35 & 31 & 16 & 47 & 28 & 23 & 51 & 38 & 26 & 64 \\
\hline Tobacco and beverages & 0 & 0 & 0 & 0 & $\mathbf{0}$ & 0 & 0 & 0 & $\mathbf{0}$ & 1 & 0 & 1 \\
\hline Crude materials and inedibles & 6 & 8 & 14 & 7 & 5 & 12 & 5 & 3 & 8 & 6 & 2 & 8 \\
\hline Animal and vegetable oil and fats & 2 & 2 & 4 & 3 & 3 & 6 & 32 & 3 & 35 & 46 & 3 & 49 \\
\hline Chemicals and drugs & 11 & 0 & 11 & 23 & 0 & 23 & 31 & 0 & 31 & 41 & 1 & 42 \\
\hline Manufactured goods, classified & 22 & 167 & 189 & 27 & 167 & 194 & 41 & 147 & 188 & 51 & 152 & 203 \\
\hline Machinery and transport equipment & 0 & 0 & 0 & 0 & 1 & 1 & 0 & 1 & 1 & 0 & 1 & 1 \\
\hline Miscellaneous manufactured articles & 1 & 104 & 105 & 1 & 113 & 114 & 4 & 126 & 130 & 10 & 158 & 168 \\
\hline Commodities and transactions n.i.e. $1 /$ & 1 & $\mathbf{0}$ & 1 & 0 & 0 & 0 & 1 & 0 & 1 & $\mathbf{0}$ & 0 & $\mathbf{0}$ \\
\hline Re-exports & 242 & 0 & 242 & 763 & 0 & 763 & 411 & 0 & 411 & 217 & 0 & 217 \\
\hline Imports, cil.f. & 444 & 906 & 1,350 & 547 & 1,203 & 1,750 & 588 & 995 & 1,582 & 601 & 894 & 1,405 \\
\hline Food and live animals & 59 & 28 & 87 & 64 & 31 & 95 & 54 & 25 & 79 & 82 & 30 & 112 \\
\hline Tobacco and beverages & 8 & 1 & 9 & 9 & 1 & 10 & 11 & 2 & 13 & 10 & 3 & 13 \\
\hline Crude materials and inedibles & 16 & 72 & 88 & 12 & 84 & 96 & 16 & 96 & 112 & 20 & $\pi$ & 97 \\
\hline Minerals, fuel and lubricants & 8 & 93 & 101 & 9 & 117 & 126 & 8 & 146 & 154 & 8 & 121 & 129 \\
\hline Animal and vegetable oil and fats & 1 & 50 & 51 & 2 & 39 & 41 & $\mathbf{0}$ & 33 & 33 & 1 & 48 & 49 \\
\hline Chemicals and drugs & 64 & 93 & 157 & 71 & 78 & 149 & 85 & 94 & 179 & 82 & 103 & 185 \\
\hline Manufactured goods, classified & 172 & 338 & 510 & 157 & 627 & 784 & 160 & 366 & 526 & 156 & 220 & 376 \\
\hline Machinery and transport equipment & 96 & 181 & 277 & 89 & 153 & 242 & 83 & 187 & 270 & 98 & 165 & 263 \\
\hline Miscellaneous manufactured articles & 18 & 51 & 69 & 22 & 48 & 70 & 22 & 42 & 64 & 21 & 37 & 58 \\
\hline Commodities and transactions n.i.e. $1 /$ & 2 & $\mathbf{0}$ & 2 & 112 & 25 & 137 & 149 & 4 & 153 & 123 & 0 & 123 \\
\hline \multicolumn{13}{|l|}{ Memonandum items : } \\
\hline Trade balance (percent of GDP) & -3.0 & -13.6 & -16.6 & 6.3 & -18.3 & -12.0 & -0.7 & -14.5 & -15.2 & -3.8 & -9.1 & -12.9 \\
\hline Exports & 6.8 & 6.5 & 13.3 & 17.4 & 6.2 & 23.6 & 11.5 & 6.3 & 17.9 & 8.1 & 6.7 & 14.8 \\
\hline Imports & 9.8 & 20.0 & 29.9 & 11.1 & 24.5 & 35.6 & 12.3 & 20.8 & 33.1 & 11.8 & 15.8 & 27.7 \\
\hline
\end{tabular}

Sources: Data provided by the Nepalese authorities; and Fund staff estimates.

1/ Includes unclassified exports and imports, and adjustments to reconcile figures with summary balance of payments data. 
Table 14. Nepal: Exports of Major Commodities, 1994/95-1998/99

(In thousands of U.S. dollars)

\begin{tabular}{|c|c|c|c|c|c|}
\hline & $1994 / 95$ & $1995 / 96$ & $1996 / 97$ & $1997 / 98$ & $1998 / 99$ \\
\hline Carpets & 154,545 & 147,843 & 155,708 & 136,970 & $-144,238$ \\
\hline Ready-made garments & 102,903 & 97,334 & 104,419 & 113,243 & 142,643 \\
\hline Hides and skins & 11,534 & 10,741 & 8,071 & 9,921 & 6,065 \\
\hline Jute goods & 4,626 & 8,207 & 9,909 & 11,648 & 12,827 \\
\hline Pulses & 9,151 & 12,014 & 18,218 & 17,064 & 17,531 \\
\hline Handicrafts & 2,903 & 1,481 & 2,492 & 2,179 & 2,397 \\
\hline Cardamon & 2,763 & 3,539 & 3,658 & 3,676 & 2,884 \\
\hline Catechu & 140 & 491 & 971 & 1,125 & 1,722 \\
\hline Ghee and vegetable ghee & 1,001 & 641 & 1,578 & 28,200 & 42,857 \\
\hline Mustard and linseed & 1,302 & 869 & 617 & 153 & 281 \\
\hline Raw jute & 1,722 & 598 & 56 & 81 & 0 \\
\hline Dried ginger & 1,542 & 855 & 815 & 670 & 539 \\
\hline Herbs & 981 & 880 & 1,238 & 1,052 & 378 \\
\hline Other exports & 58,091 & 74,542 & 89,172 & 118,142 & 160,241 \\
\hline Total merchandise exports & 353,204 & 360,035 & 396,922 & 444,124 & 534,603 \\
\hline \multicolumn{6}{|l|}{ Memorandum items: } \\
\hline (thousands of square meters) & 2,896 & 2,618 & 2,891 & 2,447 & 2,575 \\
\hline \multicolumn{6}{|l|}{ Ready-made garments } \\
\hline (thousands of pieces) & 33,505 & 27,970 & 29,954 & 34,951 & $37,747 \quad 1$ \\
\hline Pulses (metric tonnes) & 14,115 & 10,936 & 15443 & 30,567 & 28,509 \\
\hline
\end{tabular}

Sources: Data provided by the Nepalese authorities; and Fund staff estimates.

1/ Provisional. 
Table 15. Nepal: Services and Current Transfers, 1995/96-1998/99

(In millions of U.S. dollars)

\begin{tabular}{|c|c|c|c|c|c|c|c|c|c|c|c|c|}
\hline \multirow[b]{3}{*}{ Services and current transfers (net) } & \multicolumn{3}{|c|}{$1995 / 96$} & \multicolumn{3}{|c|}{$1996 / 97$} & \multicolumn{3}{|c|}{$1997 / 98$} & \multicolumn{3}{|c|}{$1998 / 99$} \\
\hline & \multirow{2}{*}{$\frac{\text { India }}{143}$} & $\begin{array}{c}\text { Third } \\
\text { Countries }\end{array}$ & \multirow{2}{*}{$\begin{array}{r}\text { Total } \\
496\end{array}$} & India & $\begin{array}{l}\text { Third } \\
\text { Countries }\end{array}$ & Total & India & $\begin{array}{l}\text { Thind } \\
\text { Countries }\end{array}$ & Total & India & $\begin{array}{l}\text { Third } \\
\text { Countries }\end{array}$ & Total \\
\hline & & 353 & & 121 & 420 & 541 & 129 & 548 & 677 & 165 & 726 & 891 \\
\hline Services (net) & 68 & 99 & 167 & 33 & 107 & 139 & 18 & 186 & 204 & 38 & 276 & 314 \\
\hline $\begin{array}{l}\text { Receipts } \\
\text { Freight and insurance } \\
\text { Transportation } \\
\text { Travel } \\
\text { Investment income } \\
\text { Government, n.i.e. } \\
\text { Other } \\
\text { Payments } \\
\text { Freight and insurance } \\
\text { Transportation } \\
\text { Travel } \\
\text { Investment income } \\
\text { Government, n.i.e. } \\
\text { Other }\end{array}$ & $\begin{array}{r}163 \\
0 \\
12 \\
98 \\
3 \\
1 \\
49 \\
95 \\
22 \\
3 \\
43 \\
2 \\
0 \\
25\end{array}$ & $\begin{array}{r}298 \\
0 \\
52 \\
74 \\
28 \\
87 \\
57 \\
199 \\
3 \\
31 \\
103 \\
31 \\
7 \\
25\end{array}$ & $\begin{array}{r}461 \\
0 \\
64 \\
172 \\
31 \\
88 \\
106 \\
294 \\
25 \\
34 \\
146 \\
33 \\
7 \\
50\end{array}$ & $\begin{array}{r}118 \\
0 \\
11 \\
62 \\
3 \\
1 \\
42 \\
85 \\
23 \\
3 \\
35 \\
1 \\
0 \\
23\end{array}$ & $\begin{array}{r}263 \\
0 \\
49 \\
88 \\
32 \\
69 \\
25 \\
156 \\
2 \\
24 \\
70 \\
28 \\
8 \\
25\end{array}$ & $\begin{array}{r}381 \\
0 \\
60 \\
149 \\
35 \\
70 \\
67 \\
241 \\
25 \\
27 \\
105 \\
29 \\
8 \\
48\end{array}$ & $\begin{array}{r}108 \\
0 \\
10 \\
56 \\
5 \\
0 \\
38 \\
90 \\
23 \\
2 \\
37 \\
1 \\
0 \\
28\end{array}$ & $\begin{array}{r}327 \\
0 \\
57 \\
104 \\
34 \\
99 \\
34 \\
142 \\
2 \\
33 \\
48 \\
24 \\
8 \\
27\end{array}$ & $\begin{array}{r}435 \\
0 \\
67 \\
160 \\
38 \\
99 \\
72 \\
232 \\
25 \\
34 \\
85 \\
25 \\
8 \\
55\end{array}$ & $\begin{array}{r}140 \\
0 \\
11 \\
53 \\
4 \\
47 \\
25 \\
102 \\
23 \\
5 \\
43 \\
1 \\
0 \\
29\end{array}$ & $\begin{array}{r}406 \\
0 \\
45 \\
126 \\
48 \\
144 \\
43 \\
130 \\
2 \\
34 \\
34 \\
26 \\
9 \\
25\end{array}$ & $\begin{array}{r}546 \\
0 \\
56 \\
179 \\
52 \\
191 \\
68 \\
232 \\
25 \\
40 \\
77 \\
27 \\
9 \\
54\end{array}$ \\
\hline Private current transfers (net) & $\$ 9$ & 133 & 192 & 69 & 240 & 309 & 89 & 266 & 355 & 108 & 362 & 470 \\
\hline $\begin{array}{l}\text { Receipts } \\
\text { Private remittances } \\
\text { Other estimated remittances } \\
\text { Payments }\end{array}$ & $\begin{array}{r}67 \\
36 \\
31 \\
8\end{array}$ & $\begin{array}{r}135 \\
42 \\
94 \\
2\end{array}$ & $\begin{array}{r}202 \\
78 \\
125 \\
10\end{array}$ & $\begin{array}{r}78 \\
32 \\
46 \\
9\end{array}$ & $\begin{array}{r}252 \\
85 \\
168 \\
12\end{array}$ & $\begin{array}{r}330 \\
117 \\
213 \\
21\end{array}$ & $\begin{array}{r}113 \\
49 \\
64 \\
25\end{array}$ & $\begin{array}{r}270 \\
89 \\
182 \\
4\end{array}$ & $\begin{array}{r}384 \\
138 \\
245 \\
29\end{array}$ & $\begin{array}{r}122 \\
66 \\
56 \\
14\end{array}$ & $\begin{array}{r}364 \\
106 \\
259 \\
2\end{array}$ & $\begin{array}{r}486 \\
172 \\
315 \\
17\end{array}$ \\
\hline Oficial current transfers (net) & 16 & 121 & 137 & 20 & 73 & 93 & 22 & 96 & 119 & 19 & 88 & 107 \\
\hline $\begin{array}{l}\text { Receipts } \\
\text { Payments }\end{array}$ & $\begin{array}{r}16 \\
0\end{array}$ & $\begin{array}{r}121 \\
0\end{array}$ & $\begin{array}{r}137 \\
0\end{array}$ & $\begin{array}{r}20 \\
0\end{array}$ & $\begin{array}{r}73 \\
0\end{array}$ & $\begin{array}{r}93 \\
0\end{array}$ & $\begin{array}{r}22 \\
0\end{array}$ & $\begin{array}{r}96 \\
0\end{array}$ & $\begin{array}{r}119 \\
0\end{array}$ & $\begin{array}{r}19 \\
0\end{array}$ & $\begin{array}{r}88 \\
0\end{array}$ & $\begin{array}{r}107 \\
0\end{array}$ \\
\hline
\end{tabular}

Sources: Data provided by the Nepalese authorities; and Fund staff estimates. 
Table 16. Nepal: External Debt and Debt Service, 1994/95-1998/99

\begin{tabular}{|c|c|c|c|c|c|}
\hline & $1994 / 95$ & $1995 / 96$ & $1996 / 97$ & $1997 / 98$ & 1998/99 \\
\hline & \multicolumn{5}{|c|}{ (In millions of U.S. dollars) } \\
\hline Debt outstanding $1 /$ & 2,295 & 2,370 & 2,483 & 2,612 & 2,729 \\
\hline Multilateral & 1,842 & 1,940 & 1,983 & 2,090 & 2,169 \\
\hline $\mathrm{AsDB}$ & 698 & 757 & 802 & 910 & 948 \\
\hline EEC & 10 & 9 & 8 & 8 & 7 \\
\hline IDA & 1,002 & 1,052 & 1,059 & 1,080 & 1,107 \\
\hline IFAD & 58 & 57 & 57 & 44 & 58 \\
\hline IMF 2/ & 55 & 43 & 34 & 25 & 21 \\
\hline NDF & 8 & 11 & 16 & 18 & 20 \\
\hline OPEC & 12 & 10 & 7 & 6 & 9 \\
\hline Bilateral & 453 & 380 & 378 & 325 & 363 \\
\hline Austria & 0 & 6 & 5 & 5 & 4 \\
\hline Belgium & 9 & 8 & 7 & 6 & 6 \\
\hline Finland & $\mathbf{0}$ & 0 & 6 & 6 & 6 \\
\hline France & 51 & 53 & 51 & 52 & 48 \\
\hline Korea & $\mathbf{0}$ & 0 & 0 & 2 & 10 \\
\hline Kuwait & 16 & 15 & 13 & 12 & 11 \\
\hline OECF & 370 & 291 & 286 & 229 & 264 \\
\hline Saudi Fund & 8 & 7 & 10 & 13 & 14 \\
\hline Short-term debt 3 / & $\cdots$ & 50 & 121 & 197 & 197 \\
\hline Total debt service & 82 & 84 & 83 & 87 & 87 \\
\hline Amortization 4/ & 59 & 60 & 55 & 62 & 61 \\
\hline Of which: To IMF 2/ & 7 & 8 & 7 & 7 & 7 \\
\hline Interest 4/ & 23 & 24 & 28 & 24 & 26 \\
\hline \multirow[t]{2}{*}{ Of which: To IMF } & 1 & 1 & 1 & 1 & 1 \\
\hline & \multicolumn{5}{|c|}{ (In percent) } \\
\hline Debt service ratio 5/ & 6.3 & 6.8 & 5.0 & 5.7 & 5.2 \\
\hline Of which: To IMF & 0.6 & 0.7 & 0.5 & 0.5 & 0.4 \\
\hline Outstanding debt/GDP & 52.1 & 52.4 & 50.5 & 54.6 & 53.8 \\
\hline Of which : To MMF & 1.3 & 1.0 & 0.7 & 0.5 & 0.4 \\
\hline
\end{tabular}

Scurces: Data provided by the Nepalese authorities; and Fund staff estimates.

1/ Consists primarily of medium- and long-term public and publicly guaranteed debt, excluding foreign liabilities of the banking system other than liabilities to the IMF.

2/ Excluding IMF Trust Fund.

3/ Outstanding trade credits.

4/ Inchudes principal and interest repayments of public enterprises and some private entities, as well as the central government.

$5 /$ In relation to exports of goods and services and private transfers. 
Table 17. Nepal: Gross International Reserves, 1994/95-1998/99 1/

\begin{tabular}{|c|c|c|c|c|c|}
\hline & $1994 / 95$ & $1995 / 96$ & $1996 / 97$ & $1997 / 98$ & $1998 / 99$ \\
\hline & \multicolumn{5}{|c|}{ (In millions of U.S. dollars, end of period) } \\
\hline \multicolumn{6}{|l|}{ Foreign exchnnge reserves } \\
\hline Nepal Restra Brnk (NRB) & 694 & 605 & 633 & 765 & 783 \\
\hline Convertible & 568 & 497 & 473 & 581 & 711 \\
\hline Nonconvertible & 126 & 108 & 160 & 184 & 72 \\
\hline Commercial banks & 169 & 200 & 218 & 286 & 346 \\
\hline Convertible & 156 & 190 & 202 & 268 & 305 \\
\hline Nonconvertible & 13 & 10 & 16 & 18 & 41 \\
\hline Total & 863 & 805 & 851 & 1,051 & 1,129 \\
\hline Convertible & 724 & 687 & 675 & 849 & 1,016 \\
\hline Nonconvertible & 139 . & 118 & 176 & 202 & 113 \\
\hline \multicolumn{6}{|l|}{ Other gross foreign assets of NRB } \\
\hline SDR holdings & 0.1 & 0.2 & 0.1 & 0.1 & 0.2 \\
\hline Gold 2/ & 6.4 & 6.5 & 6.5 & 6.5 & 6.5 \\
\hline Reserve tranche position & 8.9 & 8.2 & 8.0 & 7.6 & 7.8 \\
\hline \multirow[t]{2}{*}{ Total gross foreign assets of NRB } & 709 & 620 & 647 & 779 & 797 \\
\hline & \multicolumn{5}{|c|}{ (In months of imports of goods and services) } \\
\hline \multicolumn{6}{|l|}{ Nepal Rastra Bank } \\
\hline Gross foreign assets & 5.2 & 3.7 & 4.4 & 5.8 & 4.7 \\
\hline Foreign exchange reserves & 5.1 & 3.6 & 4.3 & 5.7 & 4.6 \\
\hline Of which: Convertible reserves & 4.1 & 3.0 & 3.2 & 4.3 & 4.2 \\
\hline
\end{tabular}

Source: Data provided by the Nepalese authorities.

1/ Totals differ from monetary sector figures owing to valuation effects.

2/ Valued at historical prices. 
Table 18. Nepal: Average Customs Duty by Main Category of Goods, 1999/2000 1/

\begin{tabular}{rlc}
\hline $\begin{array}{c}\text { Chapter } \\
\text { Numbers }\end{array}$ & \multicolumn{1}{c}{ Main Category of Goods } & $\begin{array}{c}\text { Average Customs } \\
\text { Duty 2/ } \\
\text { (n percent) }\end{array}$ \\
\hline $1-10$ & Live animals & 4.0 \\
$11-20$ & Grains, vegetable extracts, sugars & 11.5 \\
$21-30$ & Beverages, tobacco, mineral fuels, pharmaceuticals & 10.7 \\
$31-40$ & Fertilizers, cosmetics, soaps, chemicals, plastics & 14.5 \\
$41-50$ & Raw hides, skins, wood, paper, silk & 9.8 \\
$51-60$ & Wool, cotton, man-made fibres, carpets & 12.8 \\
$61-70$ & Clothing, footwear, ceramics, glassware, stoneware & 18.7 \\
$71-80$ & Iron, steel, copper, nickel, aluminium, lead, zinc, tin & 11.6 \\
$81-90$ & Tools, machinery, vehicles, aircrafts & 14.5 \\
$91-97$ & Clocks, musical instruments, arms, furniture, art & 25.4 \\
& Total number of items: 5,237 & \\
\hline & Sum of duties: 64,149 & 12.25 \\
\hline
\end{tabular}

Source: HMGN, Ministry of Finance and Department of Customs, Kathmandu, Nepal (1999).

1/ Harmonized System classification.

2/ Average of customs duties for all items in each chapter. 
Table 19. Nepal: Composition of Imports and Import Duties, 1994/95-1998/99

(In millions of Nepalese rupees)

\begin{tabular}{|c|c|c|c|c|c|}
\hline & $1994 / 95$ & $1995 / 96$ & $1996 / 97$ & $1997 / 98$ & 1998/99 \\
\hline Imports from India & 19,621 & 24,518 & 29,941 & 34,518 & 42,660 \\
\hline Of which: Dutiable imports & 18,117 & 19,369 & 23,774 & 27,282 & 25,462 \\
\hline Import duties from India & 1,854 & 2,059 & 2,359 & 2,707 & 3,430 \\
\hline As a percent of dutiable imports & 10.2 & 10.6 & 9.9 & 9.9 & 13.5 \\
\hline As a percent of total imports & 9.4 & 8.4 & 7.9 & 7.8 & 8.0 \\
\hline Imports from third countries & 43,874 & 50,029 & 71,516 & 61,812 & 49,156 \\
\hline Ofwhich: Dutiable imports & 19,602 & 34,349 & 50,701 & 52,770 & 31,334 \\
\hline Import duties from third countries & 3,986 & 4,195 & 4,748 & 4,523 & 4,479 \\
\hline As a percent of dutiable imports & 20.3 & 12.2 & 9.4 & 8.6 & 14.3 \\
\hline As a percent of total imports & 9.1 & 8.4 & 6.6 & 7.3 & 9.1 \\
\hline Total imports & 63,495 & 74,547 & 101,456 & 96,330 & 91,816 \\
\hline Of which: Dutiable imports & 37,719 & 53,718 & 74,475 & 80,052 & 56,796 \\
\hline Aid-related imports & 6,285 & 6,096 & 7,825 & 11,720 & 35,021 \\
\hline Total import duties & 5,840 & 6,254 & 7,107 & 7,230 & 7,909 \\
\hline As a percent of dutiable imports & 15.5 & 11.6 & 9.5 & 9.0 & 13.9 \\
\hline As a percent of total imports & 9.2 & 8.4 & 7.0 & 7.5 & 8.6 \\
\hline
\end{tabular}

Source: Department of Customs, Ministry of Finance. 
Table 20. Nepal: Structure of Interest Rates, 1994/95-1998/99

(Annual percentage rates, end of period)

\begin{tabular}{|c|c|c|c|c|c|}
\hline & $1994 / 95$ & $1995 / 96$ & $1996 / 97$ & $1997 / 98$ & $1998 / 99$ \\
\hline \multicolumn{6}{|l|}{ Refinancing facilities of Nepal } \\
\hline Export bills & 11.0 & 11.0 & 11.0 & 9.0 & 9.0 \\
\hline Industrial sector & 11.0 & 11.0 & 11.0 & 9.0 & 9.0 \\
\hline Agricultural sector & 11.0 & 11.0 & 11.0 & 9.0 & 9.0 \\
\hline Service sector & 11.0 & 11.0 & 11.0 & 9.0 & 9.0 \\
\hline \multicolumn{6}{|l|}{ Commercial banks } \\
\hline $\begin{array}{l}\text { Savings deposits } \\
\text { Time deposits }\end{array}$ & $7.0-8.0$ & $7.5-8.0$ & $7.5-8.0$ & $6.5-8.0$ & $5.75-8.0$ \\
\hline 3 months & $5.0-7.5$ & $6.75-8.0$ & $6.75-9.0$ & $5.0-8.0$ & $4.0-7.5$ \\
\hline 6 months & $6.0-8.0$ & $7.25-9.0$ & $7.25-9.0$ & $6.0-8.5$ & $6.0-8.0$ \\
\hline 9 months & $\ldots$ & $\ldots$ & $\ldots$ & $\ldots$ & $\ldots$ \\
\hline 1 year & $8.0-9.25$ & $9.5-11.0$ & $9.5-11.0$ & $9.0-10.5$ & $7.25-9.5$ \\
\hline 2 years & negotiable & negotiable & negotiable & $9.5-12.0$ & $7.25-10.25$ \\
\hline 3 years & negotiable & negotiable & negotiable & - & - \\
\hline 4 years & negotiable & negotiable & negotiable & - & - \\
\hline 5 years & negotiable & negotiable & negotiable & - & - \\
\hline \multicolumn{6}{|l|}{ Loans } \\
\hline Industry & $14.0-18.0$ & $15.0-17.5$ & $15.0-17.5$ & $13.5-17.0$ & $11.5-17.0$ \\
\hline Agriculture & $13.0-15.5$ & $14.5-16.0$ & $14.5-16.0$ & $14.5-15.5$ & $14.0-15.5$ \\
\hline Services & $17.0-18.0$ & 18.0 & 18.0 & 18.0 & 18.0 \\
\hline Export bills & $12.0-16.0$ & $13.0-16.0$ & $14.5-16.5$ & $12.5-16.0$ & $7.5-15.0$ \\
\hline Commercial loans and overdrafts & $12.0-19.0$ & $14.5-20.0$ & $14.5-20.0$ & $13.5-20.0$ & $10.0-19.0$ \\
\hline \multicolumn{6}{|l|}{$\begin{array}{l}\text { Agricultural Development Bank } \\
\text { of Nepal }\end{array}$} \\
\hline To cooperatives & $12.0-15.0$ & $12.0-15.0$ & $12.0-15.0$ & $13.0-16.0$ & $13.0-16.0$ \\
\hline To others & $14.0-17.0$ & $14.0-17.0$ & $14.0-17.0$ & $15.0-18.0$ & $15.0-18.0$ \\
\hline \multicolumn{6}{|l|}{ Nepal Industrial Development } \\
\hline Corporation & $15.0-16.0$ & $15.0-16.0$ & $15.5-18.0$ & $15.5-18.0$ & $15.5-18.0$ \\
\hline \multicolumn{6}{|l|}{ Government securities } \\
\hline National savings certificates & $9.0-15.5$ & $9.0-15.5$ & $9.0-13.25$ & $9.0-13.25$ & $9.0-13.25$ \\
\hline Treasury bills ( 3 month) $1 /$ & 7.4 & 10.9 & 10.2 & 3.5 & 2.3 \\
\hline Treasury bills ( 1 year) & $\ldots$ & $\ldots$ & $9.0-12.0$ & $5.9-7.3$ & $4.7-7.0$ \\
\hline Development bonds & $3.0-10.5$ & $3.0-12.0$ & $3.0-12.0$ & $3.0-12.0$ & $3.0-12.0$ \\
\hline 25-year special bonds & 3.0 & 3.0 & 3.0 & 3.0 & 3.0 \\
\hline 20-year special bonds & 5.0 & 5.0 & 5.0 & 5.0 & 5.0 \\
\hline Special loan & $1.0-14.0$ & $1.0-13.0$ & $1.0-13.0$ & $1,0-13.0$ & $8.0-9.0$ \\
\hline
\end{tabular}

Source: Data provided by the Nepalese authorities.

1/ Annual weighted average. 
Table 21. Nepal: Monetary Survey, 1994/95-1999/2000

\begin{tabular}{|c|c|c|c|c|c|c|}
\hline & $1994 / 95$ & $1995 / 96$ & 1996/97 & $1997 / 98$ & 1998/99 & $\begin{array}{l}\text { November } \\
19991 /\end{array}$ \\
\hline & \multicolumn{6}{|c|}{ (In millions of Nepalese rupees, end of period) } \\
\hline $\begin{array}{l}\text { Net foreign assets } \\
\text { Assets } \\
\text { Liabilities }\end{array}$ & $\begin{array}{r}37,085 \\
43,863 \\
6,778\end{array}$ & $\begin{array}{r}37,703 \\
45,270 \\
7,567\end{array}$ & $\begin{array}{r}40,191 \\
49,367 \\
9,176\end{array}$ & $\begin{array}{l}55,573 \\
66,114 \\
10,542\end{array}$ & $\begin{array}{l}65,027 \\
77,610 \\
12,583\end{array}$ & $\begin{array}{l}66,591 \\
80,242 \\
13,651\end{array}$ \\
\hline $\begin{array}{l}\text { Net domeatic assets } \\
\text { Domestic credit } \\
\text { Public sector } \\
\text { Government (net) } \\
\text { Nonfinancial public enterprises } \\
\text { Private sector } 2 / \\
\text { Other items (net) }\end{array}$ & $\begin{array}{r}43,899 \\
69,598 \\
23,833 \\
22,604 \\
1,229 \\
45,765 \\
-25,699\end{array}$ & $\begin{array}{r}54,953 \\
86,623 \\
26,845 \\
24,887 \\
1,958 \\
59,778 \\
-31,670\end{array}$ & $\begin{array}{r}63,530 \\
98,272 \\
28,182 \\
26,584 \\
1,598 \\
70,090 \\
-34,742\end{array}$ & $\begin{array}{r}70,890 \\
112,820 \\
29,819 \\
28,761 \\
1,059 \\
83,001 \\
41,930\end{array}$ & $\begin{array}{r}87,868 \\
131,509 \\
33,170 \\
31,604 \\
1,567 \\
98,339 \\
-43,641\end{array}$ & $\begin{array}{r}93,072 \\
137,498 \\
34,339 \\
32,846 \\
1,493 \\
103,159 \\
-44,426\end{array}$ \\
\hline $\begin{array}{l}\text { Broad money } \\
\text { Narrow money } \\
\text { Quasi-money }\end{array}$ & $\begin{array}{l}80,984 \\
32,985 \\
47,999\end{array}$ & $\begin{array}{l}92,656 \\
36,498 \\
56,158\end{array}$ & $\begin{array}{r}103,720 \\
38,460 \\
65,260\end{array}$ & $\begin{array}{r}126,463 \\
45,164 \\
81,299\end{array}$ & $\begin{array}{r}152,895 \\
51,157 \\
101,738\end{array}$ & $\begin{array}{r}159,663 \\
54,669 \\
104,994\end{array}$ \\
\hline Quasi-money & \multicolumn{6}{|c|}{ (Annual percentage change) } \\
\hline $\begin{array}{l}\text { Net domestic assets } \\
\text { Domestic credit } \\
\text { Public sector } \\
\text { Private sector 2/ }\end{array}$ & $\begin{array}{r}30.8 \\
25.1 \\
4.5 \\
39.4\end{array}$ & $\begin{array}{l}25.2 \\
24.5 \\
12.6 \\
30.6\end{array}$ & $\begin{array}{r}15.6 \\
13.4 \\
5.0 \\
17.3\end{array}$ & $\begin{array}{r}11.6 \\
14.8 \\
5.8 \\
18.4\end{array}$ & $\begin{array}{l}24.0 \\
16.6 \\
11.2 \\
18.5\end{array}$ & $\begin{array}{l}23.8 \\
18.7 \\
17.3 \\
19.2\end{array}$ \\
\hline $\begin{array}{l}\text { Broad money } \\
\text { Narrow money } \\
\text { Quasi-money }\end{array}$ & $\begin{array}{l}16.1 \\
15.7 \\
16.3\end{array}$ & $\begin{array}{l}14.4 \\
10.6 \\
17.0\end{array}$ & $\begin{array}{r}11.9 \\
5.4 \\
16.2\end{array}$ & $\begin{array}{l}21.9 \\
17.4 \\
24.6\end{array}$ & $\begin{array}{l}20.9 \\
13.3 \\
25.1\end{array}$ & $\begin{array}{l}20.8 \\
23.6 \\
19.4\end{array}$ \\
\hline Quasi-money & \multicolumn{6}{|c|}{ (12 month change in percent of broad money at start of period) } \\
\hline Net foreign assets & 1.2 & 0.8 & 2.7 & 14.8 & 7.5 & 7.3 \\
\hline $\begin{array}{l}\text { Net domestic assets } \\
\text { Domestic credit } \\
\text { Public sector } \\
\text { Private sector } 2 /\end{array}$ & $\begin{array}{r}14.8 \\
20.0 \\
1.5 \\
18.5\end{array}$ & $\begin{array}{r}13.6 \\
21.0 \\
3.7 \\
17.3\end{array}$ & $\begin{array}{r}9.3 \\
12.6 \\
1.4 \\
11.1\end{array}$ & $\begin{array}{r}7.1 \\
14.0 \\
1.6 \\
12.4\end{array}$ & $\begin{array}{r}13.4 \\
14.8 \\
2.6 \\
12.1\end{array}$ & $\begin{array}{r}13.5 \\
16.4 \\
3.8 \\
12.6\end{array}$ \\
\hline $\begin{array}{l}\text { Memorandum items: } \\
\text { Net foreign assets, } \\
\text { excluding exchange valuation } 3 / \\
\text { Net domestic assets, }\end{array}$ & -0.7 & -2.1 & 3.5 & 9.7 & 7.8 & 6.5 \\
\hline $\begin{array}{l}\text { Velocity (GDP/M2) } \\
\text { Money multiplier }\end{array}$ & $\begin{array}{l}2.71 \\
2.48\end{array}$ & $\begin{array}{l}2.69 \\
2.62\end{array}$ & $\begin{array}{l}2.70 \\
2.53\end{array}$ & $\begin{array}{l}2.34 \\
2.75\end{array}$ & $\begin{array}{l}2.26 \\
2.90\end{array}$ & $\begin{array}{l}2.32 \\
2.78\end{array}$ \\
\hline
\end{tabular}

Sources: Data provided by the Nepalese authorities; and Fund staff estimates.

1/ Estimated figures adjusted for bias in estimates.

2/ Includes credit to financial public enterprises.

3/ Adjusted for the impact of exchange rate changes on the value of net foreign assets and other items, net. 
Table 22. Nepal: Assets and Liabilities of Nepal Rastra Bank, 1994/95-1999/2000

\begin{tabular}{|c|c|c|c|c|c|c|}
\hline & $1994 / 95$ & $1995 / 96$ & $1996 / 97$ & $1997 / 98$ & $1998 / 99$ & $\begin{array}{r}\text { November } \\
1999\end{array}$ \\
\hline & \multicolumn{6}{|c|}{ (In millions of Nepalese rupees, end of period) } \\
\hline Net foreign assets & 32,338 & 31,464 & 34,474 & 46,354 & 52,607 & 54,561 \\
\hline Assets & 35,423 & 34,231 & 36,910 & 48,393 & 54,138 & 56,027 \\
\hline Liabilities & 3,085 & 2,767 & 2,436 & 2,040 & 1,531 & 1,467 \\
\hline Net domestic assets & 348 & 3,926 & 6,554 & -358 & 63 & 2,938 \\
\hline Claims on public sector & 14,414 & 17,346 & 18,846 & 18,487 & 18,852 & 21,045 \\
\hline Government (net) & 14,406 & 17,339 & 18,838 & 18,480 & 18,844 & 21,038 \\
\hline Claims $1 /$ & 14,406 & 17,339 & 18,838 & 18,480 & 18,844 & 21,038 \\
\hline Deposits & - & 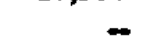 & - & - & - & - \\
\hline Nonfinancial public enterprises & 8 & 8 & 8 & 8 & 8 & 8 \\
\hline Claims on private sector $2 /$ & 1,358 & 2,082 & 2,977 & 2,801 & 3,002 & 2,866 \\
\hline Claims on commercial banks & 15 & 365 & 7 & 6 & 6 & 6 \\
\hline Other items (net) & $-15,439$ & $-15,867$ & $-15,275$ & $-21,651$ & $-21,796$ & $-20,978$ \\
\hline Reserve money & 32,686 & 35,390 & 41,027 & 45,996 & 52,670 & 57,498 \\
\hline Currency outside banks & 22,494 & 25,046 & 27,334 & 30,893 & 34,984 & 37,863 \\
\hline Currency held by banks & 2,038 & 2,446 & 2,837 & 2,890 & 3,310 & 4,015 \\
\hline Bankers' deposits & 7,017 & 6,699 & 9,273 & 10,543 & 12,208 & 12,253 \\
\hline \multirow[t]{2}{*}{ Private sector deposits } & 1,138 & 1,198 & 1,584 & 1,670 & 2,168 & 3,368 \\
\hline & \multicolumn{6}{|c|}{ (12 month change in percent of reserve money at start of period) } \\
\hline Net foreign assets & 0.8 & -2.7 & 8.5 & 29.0 & 13.6 & 13.1 \\
\hline Net domestic assets & 14.2 & 10.9 & 7.4 & -16.8 & 0.9 & 3.8 \\
\hline Reserve money & 15.1 & 8.3 & 15.9 & 12.1 & 14.5 & 16.9 \\
\hline \multicolumn{7}{|l|}{ Memorandum items: } \\
\hline $\begin{array}{l}\text { Net foreign assets, } \\
\text { excluding exchange valuation } 3 \text { / }\end{array}$ & -3.5 & -7.8 & 10.7 & 18.3 & 14.6 & 14.6 \\
\hline $\begin{array}{l}\text { Net domestic assets, } \\
\text { excluding exchange valuation } 3 /\end{array}$ & 18.5 & 16.1 & 5.2 & -6.2 & 0.0 & 2.2 \\
\hline Currency/deposits ratio 4/ & 38.5 & 37.0 & 35.8 & 32.3 & 29.7 & 31.8 \\
\hline Reserves/deposits ratio 4/ & 15.8 & 13.8 & 16.2 & 14.3 & 13.4 & 14.0 \\
\hline
\end{tabular}

Sources: Data provided by the Nepalese authorities; and Fund staff estimates.

1/ Includes Treasury IMF account.

2/ Includes claims on financial public enterprises.

3/ Adjusted for the impact of exchange rate changes on the value of net foreign assets and other items, net.

4/ Based on estimated deposits adjusted for bias in estimates. 
Table 23. Nepal: Assets and Liabilities of Commercial Banks, 1994/95-1999/2000

(In millions of Nepalese rupees, end of period)

\begin{tabular}{|c|c|c|c|c|c|c|}
\hline & $1994 / 95$ & $1995 / 96$ & $1996 / 97$ & $1997 / 98$ & 1998/99 & $\begin{array}{c}\text { November } \\
19991 / \\
\end{array}$ \\
\hline Reserves & 9,502 & 9,175 & 12,110 & 13,433 & 15,518 & 16,268 \\
\hline Foreign assets & 8,440 & 11,039 & 12,457 & 17,721 & 23,473 & 24,215 \\
\hline Claims on Government & 8,198 & 7,548 & 7,746 & 10,281 & 12,759 & 11,809 \\
\hline \multicolumn{7}{|l|}{ Claims on nonfinancial public } \\
\hline enterprises & 1,221 & 1,951 & 1,590 & 1,051 & 1,559 & 1,485 \\
\hline \multicolumn{7}{|l|}{ Claims on financial public } \\
\hline enterprises & 176 & 238 & 305 & 505 & 598 & 256 \\
\hline Claims on business and individual & 44,231 & 57,458 & 66,808 & 79,695 & 94,739 & 98,307 \\
\hline Assets = Liabilitics & 71,768 & 87,409 & 101,016 & 122,686 & 148,646 & 152,339 \\
\hline Demand deposits & 9,353 & 10,253 & 9,543 & 12,601 & 14,005 & 13,433 \\
\hline Savings deposits & 22,226 & 25,099 & 28,857 & 35,470 & 48,114 & 50,525 \\
\hline Fixed deposits & 24,320 & 29,110 & 34,536 & 44,022 & 51,612 & 49,313 \\
\hline Margin deposits & 1,453 & 1,949 & 1,867 & 1,807 & 2,011 & 2,519 \\
\hline Foreign liabilities 2 & 3,693 & 4,800 & 6,740 & 8,502 & 11,052 & 12,185 \\
\hline Borrowing from the central bank & 15 & 365 & 7 & 6 & 6 & 6 \\
\hline Other items (net) & 10,707 & 15,833 & 19,466 & 20,278 & 21,845 & 24,360 \\
\hline \multicolumn{7}{|l|}{ Memorandum item: } \\
\hline \multicolumn{7}{|l|}{ Priority sector lending in } \\
\hline percent of total domestic credit & 8.2 & 8.0 & 8.9 & 9.3 & 9.3 & ... \\
\hline
\end{tabular}

Source: Data provided by the Nepalese authorities.

1/ Based on unadjusted provisional data from NRB. The totals are not comparable with the total commercial bank aggregates shown in Table 21 and the Staff Report.

$2 /$ Includes foreign currency deposits. 
Table 24. Nepal: Assets and Liabilities of Finance Companies, 1996/97-1998/99 (End of Period)

\begin{tabular}{|c|c|c|c|c|c|c|}
\hline & \multicolumn{2}{|c|}{$1996 / 97$} & \multicolumn{2}{|c|}{$1997 / 98$} & \multicolumn{2}{|c|}{$1998 / 99$} \\
\hline & Nrs millions & Percent & Nrs millions & Percent & Nrs millions & Percent \\
\hline Cash & 36 & 0.7 & 39 & 0.5 & 110 & 1.0 \\
\hline Bank balance & 310 & 6.3 & 406 & 4.8 & 1,023 & 9.6 \\
\hline Investment & 698 & 14.3 & 2,065 & 24.6 & 1,262 & 11.9 \\
\hline Of which: Government securities & 374 & 7.6 & 1,750 & 20.8 & 932 & 8.8 \\
\hline Loans and advances & 3,623 & 74.0 & 5,391 & 64.1 & 7,219 & 67.9 \\
\hline Term loans & 1,662 & 33.9 & 2,177 & 25.9 & 3,105 & 29.2 \\
\hline Housing loans & 982 & 20.1 & 1,567 & 18.6 & 2,004 & 18.8 \\
\hline Hire purchases & 677 & 13.8 & 953 & 11.3 & 1,304 & 12.3 \\
\hline Fixed deposit receipt loans & 0 & 0.0 & 225 & 2.7 & 498 & 4.7 \\
\hline Leasing & 187 & 3.8 & 310 & 3.7 & 260 & 2.4 \\
\hline Other & 115 & 2.3 & 159 & 1.9 & 47 & 0.4 \\
\hline Other & 229 & 4.7 & 503 & 6.0 & 1,019 & 9.6 \\
\hline Assets = Liabilities & 4,896 & 100.0 & 8,404 & 100.0 & 10,633 & 100.0 \\
\hline Deposits & 3,649 & 74.5 & 6,275 & 74.7 & 8,033 & 75.5 \\
\hline Paid-up capital & 618 & 12.6 & 727 & 8.7 & 838 & 7.9 \\
\hline Borrowings & 229 & 4.7 & 228 & 2.7 & 83 & 0.8 \\
\hline Reserve & 36 & 0.7 & 59 & 0.7 & 177 & 1.7 \\
\hline Other & 364 & 7.4 & 1,115 & 13.3 & 1,502 & 14.1 \\
\hline \multicolumn{7}{|l|}{ Memorandum items: } \\
\hline Capital adequacy ratio (in percent) & $18: 6$ & & 14.6 & & 13.5 & \\
\hline Loan/deposit ratio (in percent) & 98.1 & & 85.8 & & 81.7 & \\
\hline Number of finance companies & 41 & & 44 & & 45 & \\
\hline
\end{tabular}

Source: Nepal Rastra Bank. 
Table 25. Nepal: Income Statements of Rastriya Banijya Bank and Nepal Bank Limited, 1994/95-1997/98

(In millions of Nepalese rupees)

\begin{tabular}{|c|c|c|c|c|}
\hline & $1994 / 95$ & $1995 / 96$ & $1996 / 97$ & $1997 / 98$ \\
\hline & \multicolumn{4}{|c|}{ Rastriya Banijya Bank 1/ } \\
\hline Interest income $2 /$ & 1,727 & 1,945 & 2,630 & 2,963 \\
\hline Less: interest payments & 1,294 & 1,518 & 1,865 & 2,111 \\
\hline Net interest income & 433 & 427 & 765 & 852 \\
\hline Overhead expenses & 370 & 479 & 645 & 694 \\
\hline Provision & 296 & 1,156 & 89 & 180 \\
\hline Total & 666 & 1,635 & 734 & 874 \\
\hline Operating profit & -233 & $-1,208$ & 31 & -22 \\
\hline Other income 3/ & 258 & 338 & 294 & 406 \\
\hline \multirow[t]{2}{*}{ Net profit } & 25 & -870 & 325 & 384 \\
\hline & \multicolumn{4}{|c|}{ Nepal Bank Limited } \\
\hline Interest income 2/ & 1,887 & 2,013 & 2,426 & 2,195 \\
\hline Less: interest payments & 1,204 & 1,263 & 1,515 & 1,905 \\
\hline Net interest income & 683 & 750 & 911 & 290 \\
\hline Overhead expenses & 654 & 618 & 703 & 723 \\
\hline Provision & 199 & 326 & 339 & 189 \\
\hline Total & 853 & 944 & 1,042 & 912 \\
\hline Operating profit & -170 & -194 & -131 & -622 \\
\hline Other income 3/ & 249 & 313 & 259 & 559 \\
\hline Net profit & 79 & 119 & 128 & -63 \\
\hline
\end{tabular}

Sources: Rastriya Banijya Bank and Nepal Bank Limited.

1/ 1997/98 figures for RBB are provisional.

$2 /$ Includes interest income from loan and investments. 
Table 26. Nepal: Outstanding Bank Credit to Major Public Enterprises, 1994/95-1998/99 (In millions of Nepalese nupees, end of period)

\begin{tabular}{|c|c|c|c|c|c|}
\hline & 1994/95 & $1995 / 96$ & $1996 / 97$ & $1997 / 98$ & 1998/99 \\
\hline Principal & 4,430 & 5,448 & 6,603 & 7,008 & 8,813 \\
\hline Financial institutions & 3,820 & 4,249 & 5,430 & 6,169 & 7,544 \\
\hline Agricultural Development Bank & 2,985 & 2,993 & 3,751 & 4,295 & 5,588 \\
\hline Nepal Industrial Development Corporation & 521 & 895 & 1,184 & 1,263 & 1,197 \\
\hline Rural Development Banks & 270 & 317 & 408 & 521 & 632 \\
\hline Other & 44 & 44 & 87 & 90 & 127 \\
\hline Nonfingacial public enterprises & 610 & 1,199 & 1,173 & 839 & 1,270 \\
\hline Agricultural Input Corporation & 20 & 383 & 320 & 16 & 242 \\
\hline Agricultural Tools Factory & 65 & 97 & 182 & 176 & 150 \\
\hline Janak Educational Material Center & 24 & 45 & 8 & 30 & 58 \\
\hline Cottage Industrial and Handicraft Emporium & 72 & 85 & 17 & 10 & 5 \\
\hline Himal Cement Company & 20 & 17 & 19 & 25 & 27 \\
\hline Janakpur Cigarette Factory & 78 & 134 & 146 & 145 & 121 \\
\hline Nepal Food Corporation & 103 & 195 & 317 & 266 & 427 \\
\hline Raghupati Jute Mill & 39 & 40 & 10 & 0 & 0 \\
\hline Royal Nepal Airline Corporation & 5 & 1 & 8 & 3 & 86 \\
\hline Hetauda Leather Factory & 2 & 29 & 2 & 3 & 3 \\
\hline Tobacco Development Corporation & 52 & 51 & 0 & $\mathbf{0}$ & $\mathbf{0}$ \\
\hline Nepal Coal Limited & 31 & 34 & 5 & 0 & 0 \\
\hline Other & 99 & 88 & 139 & 165 & 152 \\
\hline Overdue interest & 620 & 761 & 426 & 221 & 301 \\
\hline Financial institutions & 1 & 2 & 2 & 2 & 4 \\
\hline Nonfinancial public enterprises & 619 & 759 & 424 & 219 & 297 \\
\hline Total outstanding credit & 5,050 & 6,209 & 7,029 & 7,229 & 9,114 \\
\hline
\end{tabular}

Source: Data provided by the Nepalese authorities. 
Table 27. Nepal: Nonperforming Bank Loans of Public Enterprises, 1996/97-1998/99

(In millions of Nepalese rupees, end of period)

\begin{tabular}{|c|c|c|c|c|c|c|c|c|c|}
\hline & \multicolumn{3}{|c|}{ 1996/97 } & \multicolumn{3}{|c|}{$1997 / 98$} & \multicolumn{3}{|c|}{$1998 / 991 /$} \\
\hline & Principal & Interest & Total & Principal & Interest & Total & Principal & Interest & Total \\
\hline Nepal Food Corporation & 0 & 0 & 0 & 10 & 4 & 14 & 7 & 4 & 11 \\
\hline Tobacco Development Corporation & 0 & $\mathbf{0}$ & 0 & $\mathbf{0}$ & $\mathbf{0}$ & $\mathbf{0}$ & $\mathbf{0}$ & 0 & $\mathbf{0}$ \\
\hline Nepal Transportation Corporation & 19 & 13 & 32 & 19 & 20 & 39 & 20 & 28 & 48 \\
\hline Himal Cement Company & 2 & 0 & 2 & 0 & $\mathbf{0}$ & 0 & 2 & 0 & 2 \\
\hline Agricultural Input Corporation & $\mathbf{0}$ & 0 & $\mathbf{0}$ & 0 & 0 & $\mathbf{0}$ & 0 & 0 & 0 \\
\hline Bhaktapur Tile and Brick Corporation & 3 & 2 & 4 & 3 & 2 & 4 & 3 & 2 & 5 \\
\hline Raghupati Jute Mill & 10 & 137 & 147 & 0 & 0 & 0 & $\mathbf{0}$ & $\mathbf{0}$ & 0 \\
\hline Bansbari Shoe Factory & 0 & 0 & 0 & 0 & 0 & 0 & $\mathbf{0}$ & $\mathbf{0}$ & $\mathbf{0}$ \\
\hline Nepal Coal Limited & 0 & 0 & 0 & 0 & 0 & 0 & $\mathbf{0}$ & $\mathbf{0}$ & $\mathbf{0}$ \\
\hline Rice Exporting Companies & 13 & 100 & 112 & 13 & 90 & 102 & 3 & 32 & 35 \\
\hline \multicolumn{10}{|l|}{ Cottage Industrial and } \\
\hline Handicraft Emporium & 93 & 87 & 179 & 93. & 87 & 179 & 0 & 136 & 136 \\
\hline National Trading Ltd. & 0 & 0 & 0 & 0 & 0 & $\mathbf{0}$ & 0 & 0 & 0 \\
\hline Agricultural Tools Factory & 0 & 31 & 31 & 0 & 0 & 0 & 0 & 0 & 0 \\
\hline Adarsh Press & 0 & 0 & 0 & 0 & 0 & 0 & 0 & 0 & $\mathbf{0}$ \\
\hline Hetadua Leather Factory & 2 & 18 & 19 & 2 & 19 & 20 & 3 & 25 & 28 \\
\hline Total & 140 & 387 & 527 & 138 & 220 & 358 & 38 & 227 & 265 \\
\hline
\end{tabular}

Source: Data provided by the Nepalese authorities.

1/ Provisional. 
Table 28. Nepal: Summary of Central Government Operations, 1994/95-1999/2000 1/

\begin{tabular}{|c|c|c|c|c|c|c|c|c|}
\hline & \multirow[t]{2}{*}{$1994 / 95$} & \multirow[t]{2}{*}{$1995 / 96$} & \multirow[t]{2}{*}{$1996 / 97$} & \multicolumn{2}{|c|}{$1997 / 98$} & \multicolumn{2}{|c|}{ 1998/99 } & \multirow{2}{*}{$\frac{1999 / 2000}{\text { Budget }}$} \\
\hline & & & & Budget & $\overline{\text { Actual }}$ & Budget & $\overline{\text { Estimate }}$ & \\
\hline & \multicolumn{8}{|c|}{ (In billions of Nepalese rupees) } \\
\hline Total revenue and grants & 26.8 & 31.6 & 35.5 & 41.5 & 37.1 & 46.2 & 40.8 & 50.9 \\
\hline Total revenue & 22.9 & 26.8 & 29.5 & 35.5 & 31.7 & 38.4 & .34 .9 & -42.2 \\
\hline Tax revenue & 19.2 & 21.7 & 24.4 & 29.3 & 25.9 & 30.9 & 28.4 & 34.7 \\
\hline Nontax revenue & 3.7 & 5.1 & 5.1 & 6.1 & 5.7 & 7.5 & 6.5 & 7.5 \\
\hline Grants & 3.9 & 4.8 & 6.0 & 6.0 & 5.4 & 7.8 & 5.9 & 8.7 \\
\hline Total expenditure & 35.0 & 43.7 & 46.4 & 56.9 & 51.6 & 63.7 & 56.7 & 68.9 \\
\hline Regular expenditure & 15.2 & 18.7 & 20.7 & 24.2 & 23.0 & 27.1 & 27.1 & 29.4 \\
\hline Development expenditure & 19.8 & 25.0 & 25.7 & 32.7 & 28.6 & 36.6 & 29.6 & 39.5 \\
\hline Overall balance before grants & -12.1 & -16.9 & -16.9 & -21.4 & -20.0 & -25.3 & -21.8 & -26.8 \\
\hline Overall balance after grants & -8.2 & -12.0 & -10.9 & -15.4 & -14.6 & -17.6 & -15.9 & -18.1 \\
\hline Financing & 8.2 & 12.0 & 10.9 & 15.4 & 14.6 & 17.6 & 15.9 & 18.1 \\
\hline Net foreign losas & 5.4 & 7.1 & 6.9 & 13.1 & 9.0 & 14.5 & 11.4 & 14.1 \\
\hline Gross disbursements & 7.3 & 9.5 & 9.0 & 15.5 & 11.1 & 17.7 & 14.6 & 18.6 \\
\hline Amortization & 1.9 & 2.4 & 2.1 & 2.5 & 2.1 & 3.2 & 3.2 & 4.4 \\
\hline Net domestic financing & 2.8 & 5.0 & 4.0 & 2.3 & 5.6 & 3.1 & 4.5 & 3.9 \\
\hline Bank financing & 1.3 & 2.2 & 2.0 & 0.2 & 2.2 & 1.5 & 2.8 & 2.5 \\
\hline \multirow[t]{2}{*}{ Nonbank financing } & 1.5 & 2.8 & 2.0 & 2.1 & 3.4 & 1.6 & 1.7 & 1.4 \\
\hline & \multicolumn{8}{|c|}{ (In percent of GDP) } \\
\hline Total revenue & 10.4 & 10.8 & 10.5 & 12.1 & 10.7 & 11.8 & 10.1 & $\$ 1.1$ \\
\hline Tax revenue & 8.7 & 8.7 & 8.7 & 10.0 & 8.7 & 9.5 & 8.2 & 9.1 \\
\hline Nontax revenue & 1.7 & 2.1 & 1.8 & 2.1 & 1.9 & 2.3 & 1.9 & 2.0 \\
\hline Grants & 1.8 & 1.9 & 2.1 & 2.1 & 1.8 & 2.4 & 1.7 & 2.3 \\
\hline Total expenditure & 16.0 & 17.6 & 16.5 & 19.4 & 17.4 & 19.6 & 16.4 & 18.1 \\
\hline Regular expenditure & 6.9 & 7.5 & 7.4 & 8.2 & 7.8 & 8.3 & 7.9 & 7.7 \\
\hline Development expenditure & 9.0 & 10.0 & 9.2 & 11.2 & 9.6 & 11.3 & 8.6 & 10.4 \\
\hline Overall balance before grants & -5.5 & -6.8 & -6.0 & $-7,3$ & -6.7 & -7.8 & -6.3 & -7.0 \\
\hline Overall balance after grants & -3.7 & -4.8 & -3.9 & -5.2 & -4.9 & -5.4 & -4.6 & -4.7 \\
\hline Financing & 3.7 & 4.8 & 3.9 & 5.2 & 4.9 & 5.4 & 4.6 & 4.7 \\
\hline Net foreign loans & 2.5 & 2.8 & 2.5 & 4.5 & 3.0 & 4.5 & 3.3 & 3.7 \\
\hline Gross disbursements & 3.3 & 3.8 & 3.2 & 5.3 & 3.7 & 5.4 & 4.2 & 4.9 \\
\hline Amortization & 0.9 & 1.0 & 0.7 & 0.8 & 0.7 & 1.0 & 0.9 & 1.2 \\
\hline Net domestic financing & 1.3 & 2.0 & 1.4 & 0.8 & 1.9 & 0.9 & 1,3 & 1.0 \\
\hline Bank financing & 0.6 & 0.9 & 0.7 & 0.1 & 0.7 & 0.4 & 0.8 & 0.7 \\
\hline Nonbank financing & 0.7 & 1.1 & 0.7 & 0.7 & 1.2 & 0.5 & 0.5 & 0.4 \\
\hline \multicolumn{9}{|l|}{ Memorandum ilem: } \\
\hline Nominal GDP (Billions Nrs) & 219.2 & 248.9 & 280.5 & 293.5 & 296.5 & 325.1 & 344.9 & 381.4 \\
\hline
\end{tabular}

Sources: Data provided by the Nepalese authorities; and Fund staff estimates.

1/ Fiscal years start on July 16. 
Table 29. Nepal: Central Government Revenue, 1995/96-1999/2000

\begin{tabular}{|c|c|c|c|c|c|c|c|}
\hline & \multirow[t]{2}{*}{$1995 / 96$} & \multirow[t]{2}{*}{$1996 / 97$} & \multicolumn{2}{|c|}{$1997 / 98$} & \multicolumn{2}{|c|}{$1998 / 99$} & \multirow{2}{*}{$\frac{1999 / 2000}{\text { Budget }}$} \\
\hline & & & Budget & Actual & Budget & Estimate & \\
\hline . & \multicolumn{7}{|c|}{ (In millions of Nepalese rupees) } \\
\hline Total revenue $1 /$ & 26,820 & 29,511 & 35,491 & 31,690 & 38,385 & 34,869 & 42,187 \\
\hline Tar revenue & 21,680 & 24,424 & 29,345 & 25,940 & 30,892 & $28,351^{-}$ & $3 \overline{4}, 655$ \\
\hline Taxes on income and profits & 3,326 & 4,123 & 4,600 & 4,898 & 5,780 & 6,182 & 7,369 \\
\hline Taxes on property & 1,273 & 1,110 & 1,400 & 1,115 & 1,312 & 1,111 & 1,301 \\
\hline Registration and land revenue & 1,080 & 1,015 & 1,150 & 1,004 & 1,207 & 991 & 1,173 \\
\hline House and land rent tax & 106 & 140 & 150 & 0 & 250 & $\ldots$ & $\cdots$ \\
\hline Other property taxes & 87 & 95 & 100 & 111 & 105 & 120 & 127 \\
\hline Taxes on goods and services & 9,754 & 10,881 & 13,645 & 11,425 & 13,780 & 11,688 & 14,500 \\
\hline VAT/Sales tax 2/ & 6,431 & 7,127 & 9,440 & 7,123 & 9,420 & 7,966 & 10,460 \\
\hline Excise taxes & 1,944 & 2,298 & 3,100 & 2,886 & 3,258 & 2,832 & 3,500 \\
\hline Others $3 /$ & 1,379 & 1,457 & 1,105 & 1,416 & 1,103 & 890 & 540 \\
\hline Taxes on international trade & 7,327 & 8,309 & 9,700 & 8,502 & 10,020 & 9,370 & 11,485 \\
\hline Import taxes & 6,254 & 7,107 & 8,390 & 7,174 & 8,528 & 7,779 & 9,652 \\
\hline Indian excise refund & 900 & 1,009 & 1,100 & 1,102 & 1,160 & 1,205 & 1,385 \\
\hline Export taxes & 150 & 168 & 190 & 217 & 320 & 380 & 442 \\
\hline Other & 23 & 25 & 20 & 10 & 12 & 6 & 6 \\
\hline Nontax revenue $1 /$ & 5,140 & 5,086 & 6,146 & 5,750 & 7,492 & 6,518 & 7,532 \\
\hline Charges, fees, fines, etc. & 942 & 1,074 & 1,394 & 1,246 & 1,625 & $\ldots$ & 1,807 \\
\hline Sales of goods and services & 1,017 & 996 & 1,105 & 1,339 & 1,508 & $\cdots$ & 1,315 \\
\hline Dividends & 1,363 & 1,134 & 1,327 & 1,311 & 1,716 & $\cdots$ & 1,840 \\
\hline Royalty and fixed asset sales & 68 & 448 & 440 & 565 & 764 & $\ldots$ & 159 \\
\hline Interest receipts & 1,734 & 1,358 & 1,600 & 1,213 & 1,766 & 1,658 & 2,280 \\
\hline \multirow[t]{2}{*}{ Miscellaneous } & 16 & 76 & 280 & 76 & 114 & $\ldots$ & 130 \\
\hline & \multicolumn{7}{|c|}{ (In percent of GDP) } \\
\hline Total revenue & 10.8 & 10.5 & 12.1 & 10.7 & 11.8 & 10.1 & 11.1 \\
\hline Tax revenue & 8.7 & 8.7 & 10.0 & 8.7 & 9.5 & 8.2 & 9.1 \\
\hline Taxes on income and profits & 1.3 & 1.5 & 1.6 & 1.7 & 1.8 & 1.8 & 1.9 \\
\hline Taxes on property & 0.5 & 0.4 & 0.5 & 0.4 & 0.4 & 0.3 & 0.3 \\
\hline Taxes on goods and services & 3.9 & 3.9 & 4.6 & 3.9 & 4.2 & 3.4 & 3.8 \\
\hline VAT/Sales tax $2 /$ & 2.6 & 2.5 & 3.2 & 2.4 & 2.9 & 2.3 & 2.7 \\
\hline Excise taxes & 0.8 & 0.8 & 1.1 & 1.0 & 1.0 & 0.8 & 0.9 \\
\hline Others 3/ & 0.6 & 0.5 & 0.4 & 0.5 & 0.3 & 0.3 & 0.1 \\
\hline Taxes on international trade & 2.9 & 3.0 & 3.3 & 2.9 & 3.1 & 2.7 & 3.0 \\
\hline Nontax revenue & 2.1 & 1.8 & 2.1 & 1.9 & 2.3 & 1.9 & 2.0 \\
\hline \multicolumn{8}{|l|}{ Memorandum item: } \\
\hline Nominal GDP (Billions of Nrs.) & 248.9 & 280.5 & 293.5 & 296.5 & 325.1 & 344.9 & 381.4 \\
\hline
\end{tabular}

Sources: Data provided by the Nepalese authorities; and Fund staff estimates.

1/ Adjusted by taking out of non-tax revenue the principal repayments from corporations (classified as negative capital spending). 2/ Sales tax prior to $1997 / 98$.

3/ Includes taxes on entertainment, hotel, contracts, and air flight. Air flight revenues are now mostly retained by the Civil Aviation Authority. 
Table 30. Nepal: Central Government Expenditure by Economic Classification, 1995/96-1999/2000

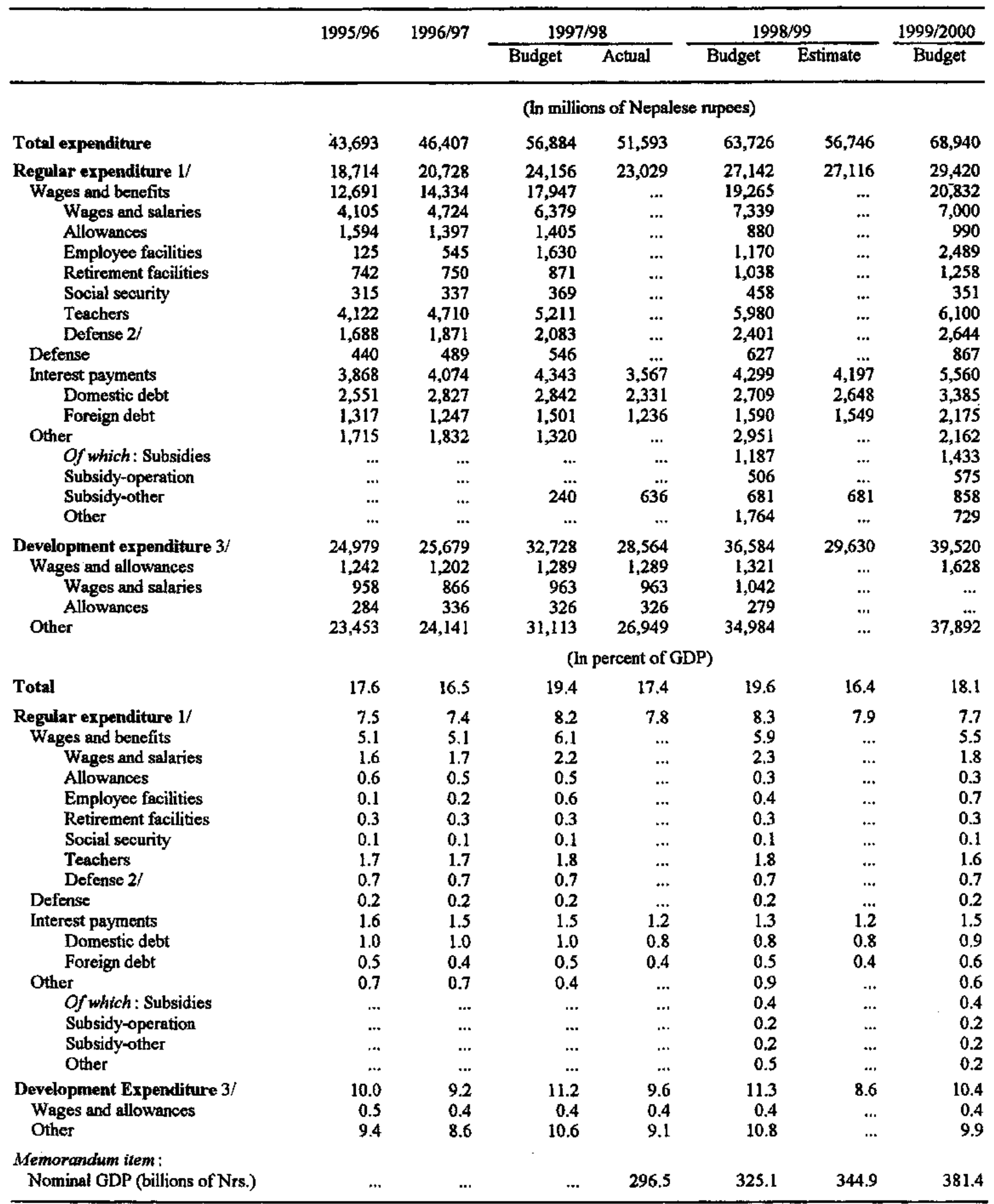

Sources: Data provided by the Nepalese authorities; and Fund staff estimates.

1/ Regular expenditure adjusted by subtracting payment of amortization on domestic and foreign loans.

2/ Wages for defense are estimated from total defense spending and assuming budgeted defense wages.

3/ Development expenditure adjusted by adding net lending (or subtracting the payment of principal from corporations). 
Table 31. Nepal: Central Government Expenditure by Functional Classification, 1995/96-1999/2000

\begin{tabular}{|c|c|c|c|c|c|c|c|}
\hline & \multirow{2}{*}{$1995 / 96$} & \multirow{2}{*}{$1996 / 97$} & \multicolumn{2}{|c|}{$1997 / 98$} & \multicolumn{2}{|c|}{$1998 / 99$} & \multirow{2}{*}{$\frac{1999 / 2000}{\text { Budget }}$} \\
\hline & & & Budget & Actual & Budget & Actual & \\
\hline & \multicolumn{7}{|c|}{ (In millions of Nepalese rupees) } \\
\hline Total expenditure & 43,693 & 46,407 & 56,884 & 51,593 & 63,726 & 56,746 & 68,940 \\
\hline $\begin{array}{l}\text { Regular expenditure } \\
\text { Social services } \\
\text { Education } \\
\text { Health } \\
\text { Other } \\
\text { Economic services } \\
\text { Agriculture related } \\
\text { Forestry } \\
\text { Infrastructure } \\
\text { Other } \\
\text { Defense } \\
\text { Interest payments } \\
\text { General administration } \\
\text { Other }\end{array}$ & $\begin{array}{r}18,714 \\
5,316 \\
4,306 \\
799 \\
211 \\
1,730 \\
365 \\
481 \\
645 \\
239 \\
2,128 \\
3,868 \\
3,141 \\
2,531\end{array}$ & $\begin{array}{r}20,728 \\
5,909 \\
4,813 \\
885 \\
211 \\
1,889 \\
371 \\
499 \\
717 \\
302 \\
2,360 \\
4,074 \\
3,532 \\
2,964\end{array}$ & $\begin{array}{r}24,156 \\
6,785 \\
5,445 \\
1,127 \\
213 \\
2,132 \\
415 \\
557 \\
852 \\
308 \\
2,629 \\
4,343 \\
4,083 \\
4,184\end{array}$ & $\begin{array}{r}23,029 \\
6,845 \\
5,571 \\
1,061 \\
213 \\
2,045 \\
391 \\
541 \\
810 \\
303 \\
2,618 \\
3,567 \\
3,930 \\
4,024\end{array}$ & $\begin{array}{r}27,142 \\
7,900 \\
6,392 \\
1,256 \\
252 \\
2,501 \\
453 \\
803 \\
934 \\
311 \\
3,028 \\
4,299 \\
4,723 \\
4,691\end{array}$ & $\begin{array}{r}27,116 \\
7,767 \\
6,322 \\
1,203 \\
242 \\
2,351 \\
436 \\
754 \\
856 \\
305 \\
2,975 \\
4,238 \\
4,580 \\
5,205\end{array}$ & $\begin{array}{r}29,421 \\
8,710 \\
6,870 \\
1,545 \\
295 \\
2,551 \\
490 \\
870 \\
865 \\
326 \\
3,511 \\
5,560 \\
5,255 \\
3,834\end{array}$ \\
\hline $\begin{array}{l}\text { Development expenditure } \\
\text { Social services } \\
\text { Education } \\
\text { Health } \\
\text { Drinking water } \\
\text { Other } \\
\text { Economic services } \\
\text { Agriculture related } \\
\text { Infrastructure } \\
\text { Other }\end{array}$ & $\begin{array}{r}24,979 \\
7,586 \\
1,698 \\
916 \\
1,112 \\
3,860 \\
17,393 \\
5,401 \\
10,384 \\
1,608\end{array}$ & $\begin{array}{r}25,679 \\
8,308 \\
2,356 \\
1,621 \\
1,327 \\
3,004 \\
17,371 \\
4,954 \\
10,904 \\
1,513\end{array}$ & $\begin{array}{r}32,728 \\
11,497 \\
2,659 \\
2,714 \\
2,224 \\
3,900 \\
21,231 \\
5,514 \\
13,190 \\
2,527\end{array}$ & $\begin{array}{r}28,564 \\
10,330 \\
2,362 \\
2,712 \\
1,683 \\
3,573 \\
18,234 \\
4,830 \\
11,279 \\
2,125\end{array}$ & $\begin{array}{r}36,584 \\
12,149 \\
2,301 \\
2,716 \\
2,656 \\
4,476 \\
24,435 \\
6,083 \\
15,491 \\
2,861\end{array}$ & $\begin{array}{r}29,630 \\
9,181 \\
1,928 \\
2,064 \\
1,838 \\
3,351 \\
20,449 \\
5,224 \\
12,351 \\
2,874\end{array}$ & $\begin{array}{r}39,520 \\
12,966 \\
3,297 \\
2,852 \\
2,709 \\
4,109 \\
26,554 \\
7,390 \\
15,038 \\
4,125\end{array}$ \\
\hline Other & \multicolumn{7}{|c|}{ (In percent of GDP) } \\
\hline Total expenditure & 17.6 & 16.5 & 19.4 & 17.4 & 19.6 & 16.4 & 18.1 \\
\hline Social services & 5.2 & 5.1 & 6.2 & 5.8 & 6.2 & 5.2 & 5.7 \\
\hline Of which: Education & 2.4 & 2.6 & 2.8 & 2.7 & 2.7 & 2.4 & 2.7 \\
\hline Current expenditure & 1.7 & 1.7 & 1.9 & 1.9 & 2.0 & 1.8 & 1.8 \\
\hline Capital expenditure & 0.7 & 0.8 & 0.9 & 0.8 & 0.7 & 0.6 & 0.9 \\
\hline Health & 0.7 & 0.9 & 1.3 & 1.3 & 1.2 & 1.2 & 1.2 \\
\hline Drinking water & 0.4 & 0.5 & 0.8 & 0.6 & 0.8 & 0.5 & 0.7 \\
\hline Economic services & 7.5 & 6.8 & 7.9 & 6.7 & 8.2 & 6.4 & 8.3 \\
\hline Of which: Agriculture related & 2.3 & 1.9 & 2.1 & 1.8 & 2.0 & 1.6 & 2.3 \\
\hline Infrastructure & 4.4 & 4.1 & 4.8 & 4.1 & 5.1 & 3.8 & 4.6 \\
\hline Defense & 0.9 & 0.8 & 0.9 & 0.9 & 0.9 & 0.9 & 0.9 \\
\hline Interest payments & 1.6 & 1.5 & 1.5 & 1.2 & 1.3 & 1.2 & 1.5 \\
\hline General administration & 1.3 & 1.3 & 1.4 & 1.3 & 1.5 & 1.3 & 1.4 \\
\hline \multirow[t]{2}{*}{ Other } & 1.2 & 1.1 & 1.5 & 1.5 & 1.5 & 1.4 & 0.3 \\
\hline & \multicolumn{7}{|c|}{ (In percent of total expenditure) } \\
\hline Social services & 29.5 & 30.6 & 32.1 & 33.3 & 31.5 & 28.7 & 31.4 \\
\hline Of which: Education & 13.7 & 15.4 & 14.2 & 15.4 & 13.6 & 14.0 & 14.8 \\
\hline Health & 3.9 & 5.4 & 6.8 & 7.3 & 6.2 & 5.5 & 6.4 \\
\hline Drinking water & 2.5 & 2.9 & 3.9 & 3.3 & 4.2 & 3.1 & 3.9 \\
\hline Economic services & 42.9 & 41.1 & 40.5 & 38.5 & 41.8 & 37.2 & 41.5 \\
\hline Of which: Agriculture related & 13.2 & 11.5 & 10.8 & 10.1 & 10.3 & 9.6 & 11.4 \\
\hline Infrastructure & 25.2 & 25.1 & 24.7 & 23.5 & 25.8 & 22.4 & 23.1 \\
\hline Defense & 4.9 & 5.1 & 4.6 & 5.1 & 4.8 & 5.0 & 5.1 \\
\hline Interest payments & 8.9 & 8.8 & 7.6 & 6.9 & 6.7 & 7.2 & 8.1 \\
\hline General administration & 7.2 & 7.6 & 7.2 & 7.6 & 7.4 & 7.8 & 7.6 \\
\hline Other & 6.6 & 6.8 & 7.9 & 8.6 & 7.9 & 14.1 & 6.3 \\
\hline
\end{tabular}

Sources: Data provided by the Nepalese authorities; and Fund staff estimates. 
Table 32. Nepal: Summary of the Tax System

(As of December 31, 1999)

Tax Nature of Tax

Exemptions and Deductions

Tax Rates

\section{Tares on net hocme and profits}

1.1 Taxes on business income
Levied on net income from public, private, and joint-

venture enterprises in

December, April, and July.

\section{Rremptions:}

Income from cottage industries, agricultural production,

fisheries, forestry, community and social services.

Industrial enterprises with tax holidays. Starting in 1997/98,

tax holidays to industrial enterprises were suspended, except

to cottuge industries. ${ }^{1}$ Existing tax holidays remained in

force for their duration (up to seven years).'

Exports are also exempted.

Deductions:

Since 1997/98, deductions of 50 percent for activities in the "National Priority" list, ${ }^{3}$ of 10 percent to enterprises using

80 pereent of local raw materials and Nepali citizens (except

tobacco and liquor), and 20-30 percent for those

established in underdeveloped areas.

Expenses incurred in carning income in the year of assessment are wholly deductible. Provident funds deposited in financial institutions. Losses, not previously offset against income, may be carried forward to be deducted against future income for a maximum of three years. Depreciation allowances are based on a straight line or diminishing balance method with the rato of write-off depending on a particular asset, concessions on the nate of depreciation are contained in the Industrial Enterprise Act. A deduction of up to 50 percent of the cost of new investment is permitted.
Tax rates

(In percent)

Industrial enterprises

Other enterprises

20

Financial institutions

\section{Surcharges}

Nepali residents

Non-Nepali residents 
Table 32. Nepal: Summary of the Tax System

(As of December 31, 1999)

\begin{tabular}{|c|c|c|c|c|}
\hline $\operatorname{Tax}$ & Nature of Tax & Exemptions and Deductions & & \\
\hline $\begin{array}{l}1,2 \text { Tax on income from individuals, } \\
\text { sole proprietorships, partnerships, } \\
\text { and private limited companies }\end{array}$ & $\begin{array}{l}\text { Levied on income accruing } \\
\text { to individuals from any } \\
\text { trade, business, profession, } \\
\text { or employment. }\end{array}$ & $\begin{array}{l}\text { The exemption for a single taxpayer is Nrs } 50,000 \text { and for a } \\
\text { married taxpayer Nrs } 60,000 \text {. } \\
\text { Deductible in determining taxable income are: } \\
\text { a. } 15 \text { percent or Nrs } 7,500 \text {, whichever is less from the } \\
\text { total remuneration after deducting the contribution made to } \\
\text { the Provident Fund. } \\
\text { b. National Provident Fund contributions to } 10 \text { percent } \\
\text { of gross salary. } \\
\text { c. Life insurance premium up to } 7 \text { percent of the policy. } \\
\text { or the actual premium, whichever is less. } \\
\text { d. Philanthropic contributions equal to } 5 \text { percent or } \\
\text { Nrs } 100,000 \text {, whichever is less. } \\
\text { e. Investments in Citizens Investment Trust up to } \\
10 \text { percent of gross salary for those setting annual salary up } \\
\text { to Nrs } 100,000 \text {. } \\
\text { Partnerships and nonresidents are given no exemptions. } \\
\text { Individual and household income from house and land rent } \\
\text { is taxed separately (i.e., not added to total income assessed) } \\
\text { at a flat rate of } 15 \text { percent on gross rental receipts; no } \\
\text { deductions are allowed. In the case of corporate rental } \\
\text { income, the following deductions are allowed: } 10 \text { percent } \\
\text { for maintenance, one-month rent commission, and } \\
\text { insurance premiums. Nevertheless, rental income is } \\
\text { effectively not taxed--due to pervasive tax evasion. }\end{array}$ & $\begin{array}{l}\text { Income bracket } \\
\text { Initial Nrs } 75,000 \\
\text { Above Nrs } 75,000 \\
\text { Surcharges } \\
\text { Nepali residents } \\
\text { Non-Nepali residents }\end{array}$ & $\begin{array}{c}\text { Tax rates } \\
\text { (n percent) } \\
15 \\
25 \\
5 \\
30\end{array}$ \\
\hline 1.3 Interest tax & $\begin{array}{l}\text { Tax payable on interest } \\
\text { income from deposits. }\end{array}$ & & 6 percent & \\
\hline 2. Taxes on property & & & ' & \\
\hline 2.1 Tax on rural land & $\begin{array}{l}\text { Levied on the size of an } \\
\text { individual's land holdings. } \\
\text { The tax rates vary with the } \\
\text { location and type of the soil. }\end{array}$ & $\begin{array}{l}\text { There is full or partial remission of the land revenue tax in } \\
\text { the presence of a drought or other natural calamity. }\end{array}$ & $\begin{array}{l}\text { For holdings of less than } \\
\text { hectare. For larger holdir } \\
\text { hectare. }\end{array}$ & $\begin{array}{l}0.6 \text { to } 10 \text { per } \\
105 \text { per }\end{array}$ \\
\hline
\end{tabular}


Table 32. Nepal: Summary of the Tax System

(As of Docember 31, 1999)

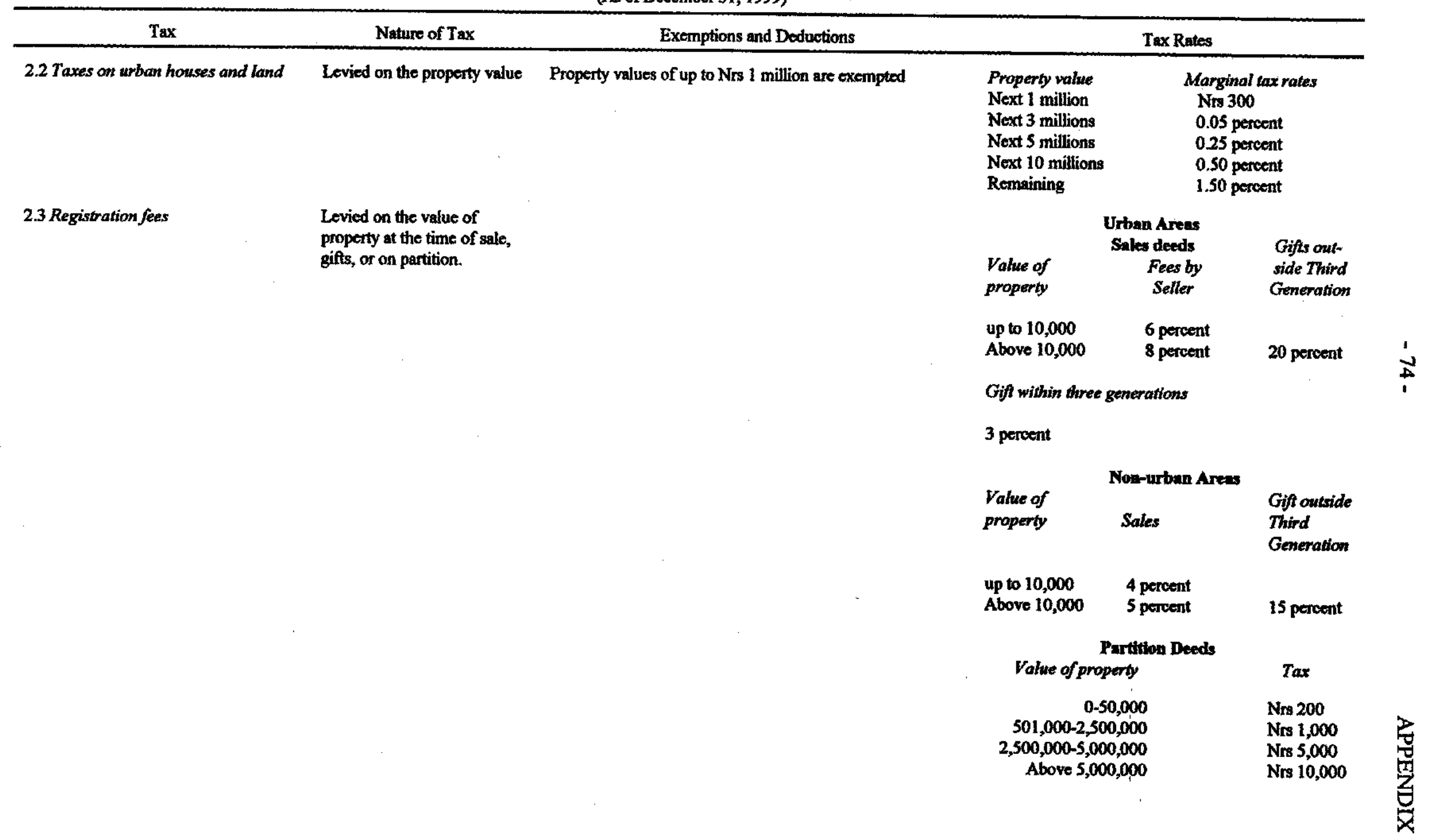


Table 32. Nepal: Summary of the Tax System

(As of December 31, 1999)

$\operatorname{Tax}$ Nature of Tax

\section{Tares on goods and services}

3.1 Value added tax

3.2 Excise taxes
Levied on goods and

services at all stages of

production and distribution.

\section{Exemption threshold: Nrs 2 million}

Bremptions:

Exports, inputs used in the production of exports, and foreign aid projects.

Equipment for agricultural, fishery, and industrial activities domestically produced cotton fabric, cotton textiles, and other textiles; cotton thread; woolen yarn; carpets; jute

products; gold ornaments; unprocessed mustard oil; aluminum, copper, and bronze circles and sheets; aeroplanes; helicopters, fire fighters, and ambulances; battery operated three-wheeler, printed material; vaccines; food and medicine for animals; equipment for processing waste and for investment in alternative energy sounces.

Additional goods exempted from VAT in the 1999/2000 budget werc agrieultural equipment, some industrial machinery, plant and main equipment required for

producing energy from bjo-gas, solar power, and air, cotton thread; cotton textiles; woolen yarn to be used in handmade sweaters; jute goods; weaving, carding, and washing of carpets; printings and publications; feed for binds and animals; vaccines, cratte, $\operatorname{cg} 8$-box and iron scrap.

Levied on some goods; the high-yielding are those on cigarettes and liquor. Enterprise Act. Industries receive a threo-year exemption,
Production of items by enterprises that are classified as new products are exempted for three years under the Industrial with an additional five-year extension, for locating in a remote area.

\section{0 percent}

\section{Spodinc tinxes \\ Ctganettes \\ Non-filtered cigarettes \\ Per 1,000 cigarettes \\ Nrs 90}

Filtered cigarettes by length

Short

Medium (70 $\mathrm{mm}$ to $75 \mathrm{~mm}$ )

Medium (75 mm to' $85 \mathrm{~mm}$ )

Long (above $85 \mathrm{~mm}$ )
Nrs 260

Nrs 335

Nrs 460

Nrs 625 
Table 32. Nepal: Summary of the Tax System

(As of December 31, 1999)

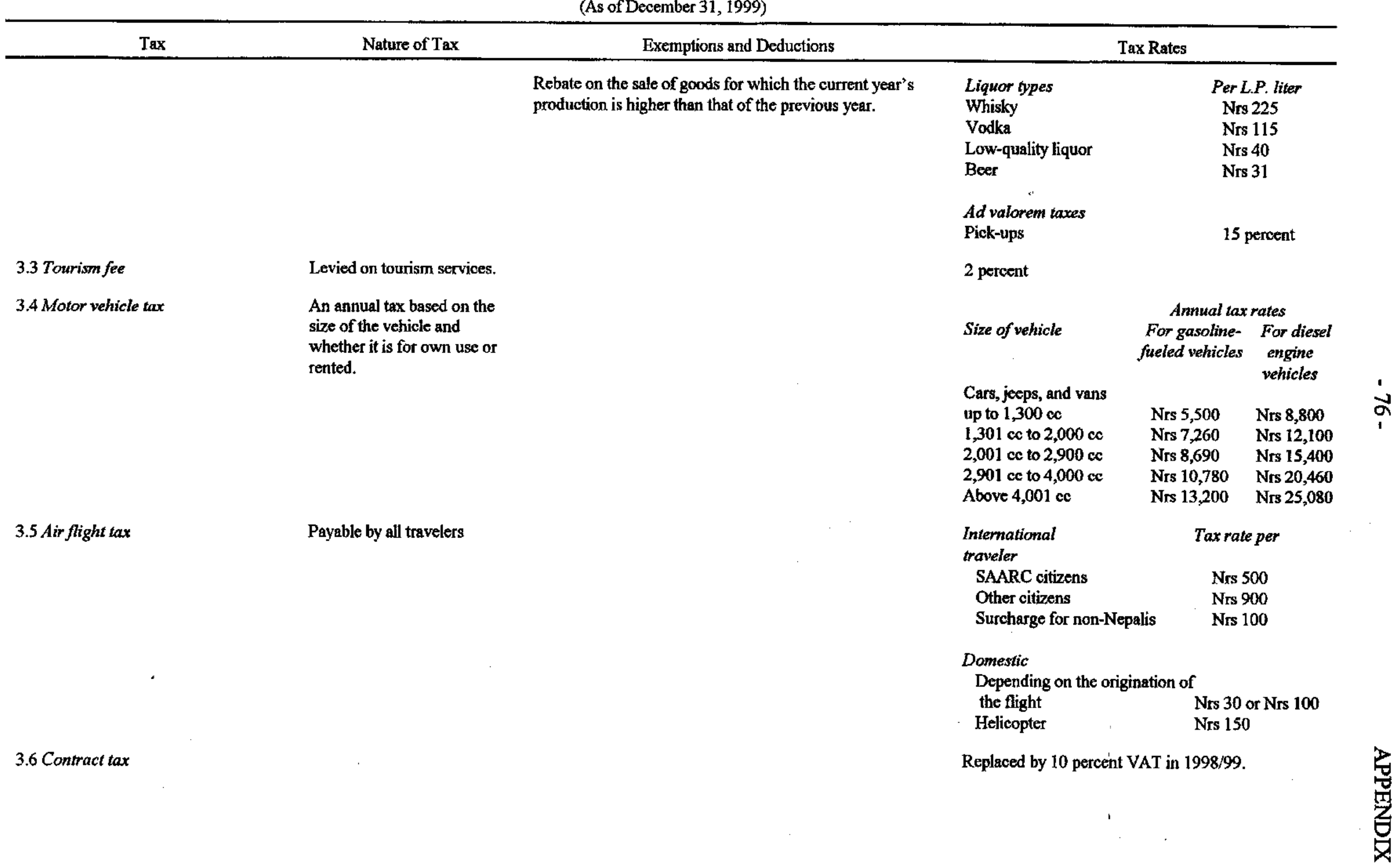


Table 32. Nepal: Summary of the Tax System

(As of December 31, 1999)

\begin{tabular}{|c|c|c|c|c|}
\hline $\operatorname{Tax}$ & Nature of Tax & Exemptions and Deductions & \multicolumn{2}{|c|}{ Tax Rates } \\
\hline \multicolumn{5}{|c|}{ 4. Taxes on international trade } \\
\hline 4.1 Import duties & $\begin{array}{l}\text { Levied on c.i.f. import } \\
\text { values. }\end{array}$ & $\begin{array}{l}\text { Exemptions: } \\
\text { Imports by the government, educational institutions, and } \\
\text { foreign aid projects. Equipment for agricultural and fishery } \\
\text { activities, food and medicine for animals, inputs for the } \\
\text { textile industry and for computers, medicine from India. } \\
\text { Deductions: } \\
50 \text { percent on industrial machinery, } 80 \text { percent on } \\
\text { aluminum, copper, and brass in block or plates. Rebates of } \\
10-20 \text { percent on imports from India and Tibet and } \\
5 \text { percent on imports from most favored countries. }\end{array}$ & $\begin{array}{l}\text { Commodity Groups } \\
\text { Roughly: } \\
\text { Raw material and machinery } \\
\text { Serni-processed materials } \\
\text { Fully processed materials } \\
\text { Consumer items } \\
\text { Luxury items } \\
\text { Development tax that replaced } \\
\text { the octroi }\end{array}$ & 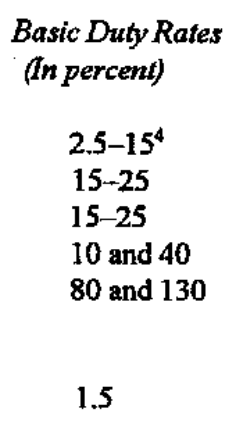 \\
\hline 4.2 Export duties & $\begin{array}{l}\text { Levied on a limited range of } \\
\text { exports }\end{array}$ & Half percent service duty on exports & $\begin{array}{l}\text { A combination of ad valorem ar } \\
\text { apply. } \\
\text { Electricity: } 2.5-10 \text { percent }\end{array}$ & specific tax rates \\
\hline
\end{tabular}

'Defined as those based on traditionaj skills and using local raw materials. Include carpet and handicraft manufacturing, textiles and clothing, leather and pottery wares, semi-precious and precious metal objects and jewelry.

${ }^{2}$ Five-year tax holidays and two-year extensions were provided by the Industrial Enterprise Act of 1992 to industries in manufacturing, mining, energy, forestry, agriculture, tourism, services, and construction.

${ }^{3}$ National priority includes hospitals, traditional medicines, transport, infrastructure, fuel saving, and pollution control.

${ }^{4}$ Slab rates of 1 and 2 percent are created by exemptions. 
Table 33. Nepal: Profits and Losses of Selected Nonfinancial Public Enterprises, 1994/95-1998/99 1/

\begin{tabular}{|c|c|c|c|c|c|}
\hline & $1994 / 95$ & $1995 / 96$ & 1996/97. & $1997 / 982 /$ & $1998 / 992 /$ \\
\hline & \multicolumn{5}{|c|}{ (In millions of Nepalese rupees) } \\
\hline Agricultural Input Corporation & .166 & -524 & -714 & -646 & -600 \\
\hline Nepal Drinking Water Corporation & 5 & 23 & 39 & 9 & 61 \\
\hline Hetauda Cement Company & -57 & 10 & 5 & 2 & 9 \\
\hline Janakpur Cigarette Factory & -41 & -51 & -105 & -7 & 8 \\
\hline Nepal Electricity Authority & 623 & 642 & 690 & 135 & -80 \\
\hline Nepal Food Corporation & 0 & 1 & -257 & -389 & -243 \\
\hline Nepal Oil Corporation & 144 & 277 & -685 & -651 & 990 \\
\hline Nepal Telecommunication Corporation (NTC) & 1,362 & 1,245 & 1,537 & 1,580 & 2,188 \\
\hline Royal Nepal Airline Corporation & -45 & 307 & -121 & 9 & .55 \\
\hline Others & 141 & -167 & 213 & 608 & -112 \\
\hline Tatal excluding NTC & 604 & 518 & -935 & -930 & -22 \\
\hline \multirow[t]{2}{*}{ Total inchuding NTC } & 1,966 & 1,763 & 602 & 650 & 2,166 \\
\hline & \multicolumn{5}{|c|}{ (In percent of GDP) } \\
\hline Agricultural Input Corporation & -0.1 & -0.2 & -0.3 & -0.2 & -0.2 \\
\hline Nepal Drinking Water Corporation & - & -- & - & - & -- \\
\hline Hetauda Cement Industry Ltd. & - & - & -- & - & - \\
\hline Janakpur Cigarette Factory Ltd. & - & - & - & - & -- \\
\hline Nepal Electricity Authority & 0.3 & 0.3 & 0.2 & 0.0 & 0.0 \\
\hline Nepal Food Corporation & - & - & -0.1 & -0.1 & -0.1 \\
\hline Nepal Oil Corporation & 0.1 & 0.1 & -0.2 & -0.2 & 0.3 \\
\hline Nepal Telecommunication Corporation (NTC) & 0.6 & 0.5 & 0.5 & 0.5 & 0.6 \\
\hline Royal Nepal Airline Corporation & -- & 0.1 & -- & - & - \\
\hline Others & 0.1 & -0.1 & 0.1 & 0.2 & - \\
\hline Total excluding NTC & 0.3 & 0.2 & -0.3 & -0.3 & 0.0 \\
\hline Total including NTC & 0.9 & 0.7 & 0.2 & 0.2 & 0.6 \\
\hline \multicolumn{6}{|l|}{ Memorcondum items : } \\
\hline Number of profit-making enterprises & 23 & 28 & 21 & 23 & 23 \\
\hline Number of loss-making enterprises & 21 & 16 & 21 & 19 & 20 \\
\hline Total number of employees $3 /$ & 53,854 & 59,455 & 47,548 & 44,721 & 46,733 \\
\hline
\end{tabular}

Source: Data provided by the Nepalese authorities.

1/ Profits before income taxes.

2/From Targets and Performances of Public Enterprises, MoF, 1999.

3/ Includes contractual, temporary, and part-time employees. 
Table 34. Nepal: Interest and Dividend Payments of Public Enterprises to Government, 1994/95-1998/99

(In millions of Nepalese rupees)

\begin{tabular}{|c|c|c|c|c|c|c|c|c|c|c|c|c|c|c|c|}
\hline & \multicolumn{3}{|c|}{$1994 / 95$} & \multicolumn{3}{|c|}{$1995 / 96$} & \multicolumn{3}{|c|}{$1996 / 97$} & \multicolumn{3}{|c|}{$1997 / 98$} & \multicolumn{3}{|c|}{$1998 / 99$} \\
\hline & Interest & Dividend & Total & Interest & Dividend & Total & Interest & Dividend & Total & Interest & Dividend & Total & Interest & Dividend & Total \\
\hline Agricultural Development Bank & 85 & 0 & 85 & 17 & 0 & 17 & 21 & 0 & 21 & 22 & 0 & 22 & $\ldots$ & $\ldots$ & $\ldots$ \\
\hline Agricultural Inputs Corporation & 0 & 0 & 0 & 0 & 0 & 0 & 0 & 0 & 0 & 0 & 0 & 0 & 0 & 0 & 0 \\
\hline Cottage Handicraft Emporium & 0 & 0 & 0 & 0 & 0 & 0 & 0 & 0 & 0 & 0 & 0 & 0 & 0 & 0 & 0 \\
\hline Credit Guarantee Corporation & 0 & $!$ & 1 & 0 & 1 & 1 & 0 & 1 & 1 & 0 & $\mathbf{i}$ & 1 & $\ldots$ & $\ldots$ & $\cdots$ \\
\hline Hetauda Cement Factory & 25 & 0 & 25 & 56 & 0 & 56 & 35 & 0 & 35 & 57 & 0 & 57 & 41 & 0 & 41 \\
\hline National Insurance Co. & 0 & 4 & 4 & 0 & 8 & 8 & $\ldots$ & $\ldots$ & $\ldots$ & $\ldots$ & $\ldots$ & $\ldots$ & $\cdots$ & $\ldots$ & $\cdots$ \\
\hline Nepal Drinking Water Corporation & $\ldots$ & $\ldots$ & $\ldots$ & 5 & 0 & 5 & $\ldots$ & ... & $\ldots$ & 6 & 0 & 6 & $\ldots$ & $\ldots$ & $\cdots$ \\
\hline Nepal Electricity Authority & 659 & 0 & 659 & 1,362 & 0 & 1,362 & 933 & 0 & 933 & 399 & 0 & 399 & 799 & 0 & 799 \\
\hline $\begin{array}{l}\text { Nepal Industrial Development } \\
\text { Corporation }\end{array}$ & 31 & 9 & 40 & 29 & 5 & 34 & 56 & 0 & 56 & $\ldots$ & $\ldots$ & $\ldots$ & 88 & 0 & 88 \\
\hline Nepal Rastra Bank & 0 & 1,250 & 1,250 & 5 & 1,250 & 1,255 & 7 & 1,100 & 1,107 & 10 & 1,150 & 1,160 & $\ldots$ & 600 & 600 \\
\hline Nepal Transport Corporation & 0 & 0 & 0 & 0 & 0 & 0 & 0 & 0 & 0 & 0 & 0 & 0 & 0 & 0 & 0 \\
\hline Royal Nepal Airlines & 0 & 0 & 0 & 0 & 0 & 0 & 0 & 0 & $\mathbf{0}$ & 0 & 0 & 0 & 0 & 0 & 0 \\
\hline Salt Trading Corp. & $\cdots$ & $\cdots$ & $\cdots$ & 0 & 1 & 1 & $\cdots$ & $\cdots$ & $\ldots$ & 0 & 1 & 1 & $\cdots$ & $\cdots$ & $\cdots$ \\
\hline Securities Exchange Centre & 0 & 0 & 0 & 0 & 0 & 0 & 0 & 0 & 0 & 0 & 0 & $\mathbf{0}$ & 0 & 0 & 0 \\
\hline Others & 289 & 7 & 295 & 260 & 93 & 353 & 305 & 33 & 339 & 331 & 4 & 335 & 278 & 148 & 426 \\
\hline Total & 1,089 & 1,271 & 2,359 & 1,734 & 1,358 & 3,092 & 1,357 & 1,134 & 2,492 & 825 & 1,156 & 1,980 & 1,206 & 748 & 1,954 \\
\hline
\end{tabular}

Sources: Targets and Performances of Public Enterprises (FY 1997/98-1999/00) and Ministry of Finance 1999. 
Table 35. Nepal: Summary of the Privatization Process

Enterprise Name
Value in millions of U.S. dollars

Number of
employees

Form of

Privatization
Date of

Privatization

\section{Privatived enterprises}

1. Bhrikuti Pulp and Paper

$$
\text { Factory }
$$

2. Harisiddhi Bricks and Tiles Factory

3. Leatherge Bansbari Tannery and Shoes Factory

4. Nepal Film Development Company

5. Balaju Textiles Industry Ltd.

6. Raw Hide Collection and Development Company

7. Nepal Jute Development and Trading Company

8. Nepal Lube Oil Limited

9. . Bitumen and Barrel Industries Ltd.

10. Tobacco Development Company

11. Nepal Foundry Industry

12. Ragupati Jute Mills

13. Biratnagar Jute Mills

14. Agriculture Tools Factory Ltd.

15. Bhaktapur Brick Factory Ltd.

16. Nepal Bank Ltd. 2/

3.0

3.3

\section{Public sector enterprises being privatieed}

1. Nepal Tea Development Corporation 3/

2. Himal Cement Company 4/

3. Butwal Power Company

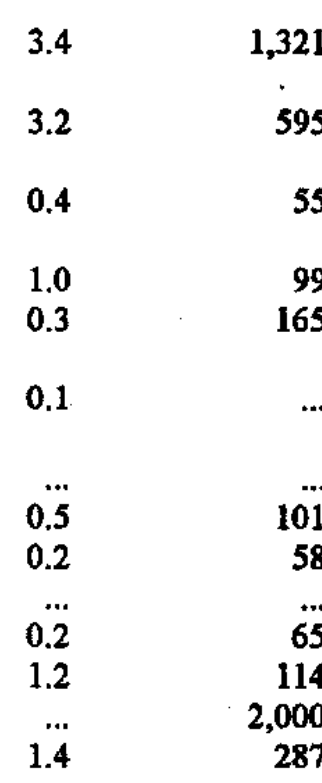

287
Share sale

Share sale

Share sale

Share sale

Share sale

Share sale

Liquidated in 1993

Share sale

Share sale

Liquidated in 1994

Share sale

Share sale

Leased

Share sale: 5 percent to employees, 65 percent to one and 30 percent retained.

Leased

Government share reduced to 41 percent. private-sector party,
October 1992

October 1992

November 1992

November 1993

December 1993

December 1993

June 1994

June 1994

March 1996

August 1996

December 1996

May 1997

August 1997 1/

February 1997
4

2,000

1.5-2

905

Share sale: 5 percent to employees, 30 percent to general public, and 65 percent to one private-sector party. Share sale

March 1998, completion in February 2000

May 1998, completion expected in March 2000

$25-30$
Jan. 10, 1999 completion delayed
Share sale: $2-3$ percent
to employees,
$2-3$ percent to United
Mission to Nepal,
75 percent to one
private-sector party,
and 20 percent retained. 
Table 35. Nepal: Summary of the Privatization Process (Continued)

Form of

of U.S. dollars employees Privatization

Date of

Privatization

II. Public sector enterprises to be privatized 5/

Financial institutions

1. Rastriya Banijya Bank 6/

2. Rastriya Beema Sansthan (insurance company)

3. Nepal Housing and Finance Company

Nonfinancial Institutions

4. Nepal Telecommunication Corporation

5. Royal Nepal Airline Corporation

6. Dairy Development Corporation (Pokhara Unit)

7. Nepal Rosin and Turpentine

8. Lumbini Sugar Factory

9. Janakpur Cigarette

10. Nepal Transport Corporation

11. Incustrial District Management Lid.

12. Agriculture Lime Industry

13. Agriculture Project Service Center

14. Herbs Production and Processing Center

15. Hetauda Textile Industry

16. Morang Sugar Millis

17. Birendra International Conference * Center

18. Nepal Orind Magnesite Industry

19. Butwal Spinning Mills

20. Udayapur Cement Factory

21. Hetauda Cement Factory

22. Cotton Development Board

$\begin{array}{rr}9.7 & 6,299 \\ 3.9 & 5,914 \\ 5.1 & 368 \\ 0.7 & 17 \\ 85.7 & 14,052\end{array}$

$153.6 \quad 4,516$

$-4.8 \quad 1,818$

$6.0 \quad 1,158$

$0.8 \quad 1,011$

$3.6 \quad 861$

$1.8 \quad 1,907$

$0.6 \quad 865$

1.9283

$0.1 \quad 86$

$-0.4 \quad 171$

$-0.2 \quad 185$

$-0.6 \quad 934$

$\cdots$

$-34.8 \quad 320$

$-447 \quad \ldots$

$\begin{array}{rr}44.7 & 720 \\ 2.8 & 934\end{array}$
Not yet decided.

Source: Ministry of Finance.

1/ The government repossessed the company, as the lessee failed to operate the company satisfactorily. A legal settlement is pending.

2/ A sale of 10 percent of the shares reduced government participation to 41 percent in February 1997.

$3 /$ Offers received in 1999, and associated payments, were not considered satisfactory. A proposal for privatization is being considered by $\mathrm{MoF}$ and $\mathrm{Mol}$.

4/ The preferred bidder could not meet financial commitment and negotiations to be finalized with second preferred bidder in February pending compromise on severance pay awards to administrative staff that are to be made redundant.

5/ Net worth estimates for end-1998/99, as reported in Targets and Performances of Public Enterprises FY 1997/981999/2000 published by the Ministry of Finance in July 1999. The conversion from Nepalese rupees to U.S. dollars was done at the rate of Nrs 68.5=US\$1.

6/ A share issue is planned through brokers in 2000. Selection of broker and percentage to be determined. 